University of Miami Law School University of Miami School of Law Institutional Repository

1991

\title{
Legal Images of Battered Women: Redefining the Issue of Separation
}

Martha R. Mahoney

University of Miami School of Law, mmahoney@law.miami.edu

Follow this and additional works at: https://repository.law.miami.edu/fac_articles

Part of the Law and Gender Commons, and the Law and Society Commons

\section{Recommended Citation}

Martha R. Mahoney, Legal Images of Battered Women: Redefining the Issue of Separation, 90 Mich. L. Rev. 1 (1991).

This Article is brought to you for free and open access by the Faculty and Deans at University of Miami School of Law Institutional Repository. It has been accepted for inclusion in Articles by an authorized administrator of University of Miami School of Law Institutional Repository. For more information, please contact library@law.miami.edu. 


\title{
LEGAL IMAGES OF BATTERED WOMEN: REDEFINING THE ISSUE OF SEPARATION
}

\author{
Martha R. Mahoney*
}

TABLE OF CONTENTS

INTRODUCTION $. . . \ldots \ldots \ldots \ldots \ldots \ldots \ldots \ldots \ldots \ldots \ldots \ldots \ldots, 2$

I. VIOLENCE AND THE ORDINARY LIVES OF WOMEN ..... 10

A. The Prevalence of Violence and the Phenomenon of Denial ................................... 10

B. Motherhood: Connectedness and Violence Against Women ................................... 19

II. Definitions OF BATtering AND BatTered WoMen.. 24

A. Identification as a "Battered Woman"............ 24

B. Evolution of The Definition of the Problem......... 26

C. The Attempt To Define the Battered Woman ........ 28

III. Pressures of THe Legal System ................ 34

A. Self-Defense, the Battered Woman Syndrome, and Learned Helplessness ........................ 34

B. Custody and the Professional Evaluation of Women . 43

C. Lesbian Battering: Defining a Problem Outside the Legal System .............................. 49

IV. Power, Control, Autonomy, AND SeParation ..... 53

A. Identifying Domination in Violence Against Women. 53

B. “Who Says She Didn't Leave?": Challenging Perceptions of Separation and Autonomy .......... 61

C. Strategies for Change and the Redefinition of Separation..................................

V. The Uses of a Name: Separation Assault AND

LEgAL DoctRINe ..............................

* Associate Professor of Law, University of Miami School of Law. B.A. 1981, Regents College; M.A. 1985, Tulane University; J.D. 1989, Stanford Law School. - Ed. Glynda Avilla, Heather Bell, Donna Coker, Mary Dunlap, Bryan Ford, Mark Kelman, Christine Littleton, and Stephanie Wildman made suggestions and comments on earlier drafts. Ken Casebeer and Lynne Henderson offered extraordinary support, helping preserve and develop my argument. Kim Hanson, Esq., J.D. Stanford Law School 1987, set an example of intellectual and emotional courage ("tell my story and use my name") and would not let me stop working on battered women's issues. All errors are my own. This article is dedicated, with gratitude, to Kim and the other women who talked with me about their experiences. 

A. Recognizing Separation Assault in the Cases: The Problem of the Dead Woman's Voice ............. 71
B. Recognizing the Danger To Women at Separation ... 75
C. Live Women and Dead Men: The Self-Defense

Cases ................................... 79

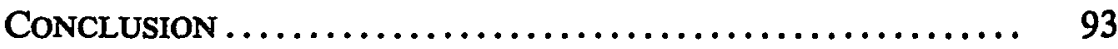

... I found an
announcement/not the woman's
bloated body in the river/floating
not the child bleeding in the
59 th street corridor/not the baby
broken on the floor/
"there is some concern
that alleged battered women
might start to murder their
husbands and lovers with no
immediate cause"1

\section{INTRODUCTION}

I am writing about women's lives. Our lives, like everyone's, are lived within particular cultures that both reflect legal structures and affect legal interpretation. Focusing on domestic violence, this article describes an interrelationship between women's lives, culture, and law. This relationship is not linear (moving from women's lives to law, or from law to life) but interactive: cultural assumptions about domestic violence affect substantive law and methods of litigation in ways that in turn affect society's perceptions of women; both law and societal perceptions affect women's understanding of our own lives, relationships, and options; our lives are part of the culture that affects legal interpretation and within which further legal moves are made. Serious harm to women results from the ways in which law and culture distort our experience.

The courtroom is the theater in which the dramas of battered women have been brought to public attention. Trials like that of Francine Hughes, whose story became the book and movie The Burning $B e d,^{2}$ create a cultural and legal spotlight that has in some ways benefited women by increasing public knowledge of the existence of domestic violence. However, the press has emphasized sensational cases that have a high level of terrorism against women and a gro-

1. Ntozake Shange, With No Immediate Cause, in FAMIL, VIOLEnCE: PoEMS ON THE PATHoLogy 66, 67 (Mary McAnally ed., 1982).

2. Faith MCNulty, The Burning Bed (1980). 
tesque quality of abuse. ${ }^{3}$ These cases come to define a cultural image of domestic violence, and the women in these cases define an image of battered women.

These images disguise the commonality of violence against women. $\mathrm{Up}$ to one half of all American women - and approximately two thirds of women who are separated or divorced - report having experienced physical assault in their relationships. ${ }^{4}$ However, litigation and judicial decisionmaking in cases of severe violence reflect implicit or explicit assumptions that domestic violence is rare or exceptional. ${ }^{5}$

For actors in the courtroom drama, the fiction that such violence is exceptional allows denial of the ways in which domestic violence has touched their own lives. ${ }^{6}$ Perhaps most damagingly, the fiction of exceptionality also increases the capacity of women to deny that the stories told in the publicized courtroom dramas have anything to do with our own lives. Therefore, it limits the help we may seek when we encounter trouble, the charges we are willing to file, our votes as jurors when charges have been filed by or against others, and our consciousness of the meaning of the struggles and dangers of our own experience.

Although domestic violence is important in many areas of legal doctrine, including family law and torts, the criminal justice system places the greatest pressures on cultural images of battered women. The self-defense cases in which women kill their batterers are small in number compared to the overall universe of domestic violence, ${ }^{7}$ yet they are highly emotionally charged as well as highly publicized. In many states, the right to expert testimony on behalf of these defendants has been won through much dedicated feminist litigation. ${ }^{8}$ The justification for admitting expert testimony is determined in large part by cultural perceptions of women and of battering; therefore, many points made by experts respond to just these cultural perceptions. ${ }^{9}$

3. See Julie Blackman, Emerging Images of Severely Battered Women and the Criminal Justice System, 8 BEHAVIORAL SCI. \& L. 121 (1990). Women who kill their batterers are likely to have experienced extremely severe violence during the course of their marriages. See ANGELA BROWNE, WHEN BATTERED WOMEN KnL (1987).

4. For discussion of the estimates of the incidence of domestic violence in the United States, see infra text accompanying notes 36-44.

5. See, e.g., quotations given in text and cases cited at notes 153-69 infra.

6. See infra notes 58-61 and accompanying text (discussing influence on courtroom participants of their own experiences of violence).

7. See infra note 140 and accompanying text.

8. See, e.g., State v. Kelly: Amicus Briefs, 9 Women's RTs. L. Rep. 245 (1986).

9. See, e.g., State v. Kelly, 478 A.2d 364, 378 (N.J. 1984) ("[Expert testimony] is aimed at an area where the purported common knowledge of the jury may be very much mistaken ... an area where expert knowledge would enable the jurors to disregard their prior conclusions as being common myths rather than common knowledge."); see infra text accompanying notes 153-69 
Yet the expert testimony on battered woman syndrome and learned helplessness can interact with and perpetuate existing oppressive stereotypes of battered women. ${ }^{10}$

Academic expertise on women has thus become crucial to the legal explanation of women's actions and the legal construction of women's experience. Psychological analysis, in particular, has responded to the sharp demand for explanation of women's actions in the self-defense cases. ${ }^{11}$ Yet the sociological and psychological literature still reflect some of the oppressive cultural heritage that has shaped legal doctrines. ${ }^{12}$ Even when expertise is developed by feminists who explain that women act rationally under circumstances of oppression, courts and the press often interpret feminist expert testimony through the lens of cultural stereotypes, retelling a simpler vision of women as victims too helpless or dysfunctional to pursue a reasonable course of action. ${ }^{13}$ These retold stories affect other areas of law, such as custody cases, which share the problems of professional evaluation of women and the incorporation of cultural stereotypes. ${ }^{14}$ The portrait of battered women as pathologically weak - the court's version of what feminists have told them - therefore holds particular dangers for battered women with children.

Legal pressures thus distort perceptions of violence in ways that

(expert testimony based on issue being beyond jury's ken). A telling example of the relationship between the need for expert testimony and the points made by experts is the issue of women's "failure" to leave violent relationships. Many cases review the jury's common-sense belief that women can and will leave violent relationships freely. The experts explain the women's incapacity and failure as a function of many factors, especially the psychology of abused women and traditionalism about the family. See, e.g., People v. Torres, 488 N.Y.S.2d 358, 361-62 (Sup. Ct. 1985); State v. Kelly, 478 A.2d 364, 370-73.

10. See Elizabeth M. Schneider, Describing and Changing: Women's Self-Defense Work and the Problem of Expert Testimony on Battering, 9 WoMEN's RTS. L. REP. 195 (1986); Lenore Walker, $A$ Response to Elizabeth M. Schneider's Describing and Changing, 9 WoMEN's RTs. L. REP. 223-25 (1986).

11. For example, see three recent books on this subject: JUlie BlackMAN, INTIMATE VIoIENCE (1989); Cynthia Gillespie, Justifiable Homicide (1989); LeNORE Walker, TerRIFYING LOVE (1989).

12. Compare R. Emerson Dobash \& Russell Dobash, Violence Against Wives 193. 99 (1979) (describing traditional psychological approaches) and EDWARD GONDOLF \& ELLEN Fisher, Battered WOMEn as Survivors: AN AIternative to Treating Learned HELPLESSNESS 13-15 (1988) (describing psychological views of women as masochistic) with DOBASH \& DOBASH, supra, at 211-26 (criticizing the legal system).

13. Schneider, supra note 10 , at 198.

14. In contested custody decisions, for example, women are also at risk that either too little strength or too much strength may be held against them. See generally PhyLLIs CHESLER, MotHers ON TRIAL: THE BATTLE FOR ChILdREN AND CuSTOdy (1986). Therefore, the portrait of battered women as pathologically weak - the courts' version of what feminists have told them - may disserve battered mothers seeking custody. Myra Sun \& Elizabeth Thomas, Custody Litigation on Behalf of Battered Women, 21 ClearINGHouse ReV. 563, 570 (1987); Laura Crites \& Donna Coker, What Therapists See That Judges May Miss, JuDGes J., Spring 1988, at 8, 13 (1988). See infra text accompanying noies 223-25. 
create real problems for women. Many of us cannot recognize our experience in the cultural picture that develops under the influence of legal processes. The consequence is that we understand ourselves less, our society less, and our oppression less, as our capacity to identify with battered women diminishes ("I'm not like that"). Before the feminist activism of the early 1970s brought battering to public attention, society generally denied that domestic violence existed. ${ }^{15}$ Now, culturally, we know what it is, and we are sure it is not us.

Recent feminist work on battering points to the struggle for power and control - the batterer's quest for control of the woman - as the heart of the battering process. ${ }^{16}$ Case law and the popular consciousness that grows from it have submerged the question of control by psychologizing the recipient of the violence ${ }^{17}$ or by equating women's experience of violence with men's experience. ${ }^{18}$ We urgently need to develop legal and social explanations of women's experience that illuminate the issue of violence as part of the issue of power, rather than perpetuating or exacerbating the images that now conceal questions of domination and control.

As one example of a strategic effort to change both law and culture, this article proposes that we seek to redefine in both law and popular culture the issue of women's separation from violent relationships. ${ }^{19}$ The question "why didn't she leave?" shapes both social and legal inquiry on battering; much of the legal reliance on academic expertise on battered women has developed in order to address this question. At the moment of separation or attempted separation - for many women, the first encounter with the authority of $1 \mathrm{law}^{20}$ - the batterer's quest for control often becomes most acutely violent and

15. See infra text accompanying note 94 (discussing the role of feminist activists in bringing national attention to domestic violence).

16. See infra text accompanying notes 131-35.

17. See GONDOLF \& FISHER, supra note 12, at 1-3 (describing "psychologizing" of domestic violence).

18. See Phyllis Crocker, The Meaning of Equality for Battered Women Who Kill in SelfDefense, 8 HARV. WomEN's L.J. 121 (1985); see also GiLlESPIE, supra note 11, at 115-17 (discussing women's and men's differing experiences of violence in layperson's terms).

19. Redefining separation must include rethinking many assumptions - that it is the woman's job to separate from a battering relationship, that separation is the appropriate choice for all women when violence first occurs within a relationship, that appropriate separation is an immediate and final break rather than the process of repeated temporary separations made by many women - as well as identifying the violent assault on women's attempts to separate.

20. These encounters may take many forms, including the attempt to have a violent partner arrested, the filing of a temporary restraining order or legal separation, or the rush to find legal counsel because the partner has threatened to take custody of the children. See, eg., infra text accompanying notes $200-01$ (discussing custody litigation). 
potentially lethal. ${ }^{21}$ Ironically, although the proliferation of shelters ${ }^{22}$ and the elaboration of statutory structures facilitating the grant of protective orders ${ }^{23}$ vividly demonstrate both socially and legally the dangers attendant on separation, a woman's "failure" to permanently separate from a violent relationship is still widely held to be mysterious and in need of explanation, an indicator of her pathology rather than her batterer's. We have had neither cultural names nor legal doctrines specifically tailored to the particular assault on a woman's body and volition that seeks to block her from leaving, retaliate for her departure, or forcibly end the separation. I propose that we name this attack "separation assault."

Separation assault is the common though invisible thread that unites the equal protection suits on enforcement of temporary restraining orders, the cases with dead women that appear in many doctrinal categories, ${ }^{24}$ and the cases with dead men - the self-defense cases. As with other assaults on women that were not cognizable until the feminist movement named and explained them, ${ }^{25}$ separation assault must be identified before women can recognize our own experience and before we can develop legal rules to deal with this particular sort of violence. Naming one particular aspect of the violence then illuminates the rest: for example, the very concept of "acquaintance rape" moves consciousness away from the stereotype of rape (assault by a stranger) ${ }^{26}$ and toward a focus on the woman's volition (violation of her will, "consent"). Similarly, by emphasizing the urgent control moves that seek to prevent the woman from ending the relationship,

21. See Desmond Ellis, Post-Separation Woman Abuse: The Contribution of Lavyers as "Barracudas," "Advacates," and "Counsellors," 10 INTL. J.L. \& PsYchiATrY 403, 408 (1987). Many authors note the dangers of this period. See, e.g., GILlESPIE, supra note 11, at 150-52; ANN JONES, WOMEN WHO KILL 298-99 (1980).

22. GONDOLF \& FisHeR, supra note 12, at 1.

23. Id.

24. These cases are often concerned with the mental state or sentences of the murderer. See, e.g., infra text accompanying notes 325-26, 351-57 (discussing provocation and manslaughter). Another example appears in several Ninth Circuit cases on competency to plead guilty, including Darrow v. Gunn, 594 F.2d 767, 771 n.6 (9th Cir.), cert. denied, 444 U.S. 849 (1979) (wife murder); Sailer v. Gunn, 548 F.2d 271, 273 (9th Cir. 1977) (attempted murder of estranged wife); de Kaplany v. Enomoto, 540 F.2d 975 (9th Cir. 1976), cert denied, 429 U.S. 1075 (1977) (wife murder).

25. The example I discuss below is "date rape." See infra text accompanying nntes 304-05. Sexual harassment is another such example. In her book Sexual Harassment of Working Women, Catharine MacKinnon defined sexual harassment in terms of power and inequality ("sexual harassment ... refers to the unwanted imposition of sexual requirements in the context of a relationship of unequal power") and argued that sexual harassment was sex discrimination. Catharine Mackinnon, Sexual Harassment of Working Women 1, 4 (1979). Within a decade, this argument had transformed both sex discrimination law and cultural understanding of sexual harassment.

26. SUSAN EsTrich, REAL RAPE 3-4 (1987). 
the concept of separation assault raises questions that inevitably focus additional attention on the ongoing struggle for power and control in the relationship.

Because of the interactive relationships between law and culture in this area, law reform requires such an approach to simultaneously reshape cultural understanding. Separation assault is particularly easy to grasp because it responds to prevailing cultural and legal inquiry ("why didn't she leave") with a twist emphasizing the batterer's violent quest for control. However, meaningful change requires rethinking the entire relationship of law and culture in the field of domestic violence and developing many approaches to revealing power and control. Otherwise, since separation assault is so resonant with existing cultural stereotypes, it may be understood as justifying or excusing the woman's failure to leave rather than challenging and reshaping legal and social attitudes that now place this burden on the woman.

To illustrate the contrast between women's lives and legal and cultural stereotypes, and to accomplish a translation between women's lives and law, this article offers narratives and poems from the lives of survivors of domestic violence, and a few from the stories of nonsurvivors, as part of its analysis and argument. ${ }^{27}$ Seven women's stories have come to me through their own accounts. ${ }^{28}$ Five of these have

27. Conversations with women are cited several times in the footnotes of this article. Particularly thoughtful input has come from Kim Hanson and Donna Coker. This citation form is deliberately chosen and consistent with the method of the article. Each citation credits the woman with an original thought or contribution that has not appeared in a form suitable for conventional citation as this article goes to press.

There are three reasons for my choice of citation form. The first is honesty: when other women who have not yet published scholarly work have offered me so much of their best thought - and it has become so deeply part of my own best thought - I must either falsely claim their ideas as my own or credit them as they spoke. The second reason is methodological: much of feminist theory, and much of the strength women draw upon for survival, grows out of conversations with each other. This is, for example, the fundamental method of consciousness-raising. See, e.g., Ronnie Lichtman, Consciousness Raising - 1970, in THE Female EXPERIENCE 456 (Gerda Lerner ed., 1977). For a discussion of consciousness-raising and its role in feminist method, see, e.g., Christine A. Littleton, Feminist Jurisprudence: The Difference Method Makes, 41 Stan. L. Rev. 751 (1989) (reviewing CATHaRINE MacKinnon, Feminism Unmodified (1987)).

Finally, the third reason for citing women's conversations is political: women may not have published their thoughts because of constraints on their time and effort imposed by uniquely womanly responsibilities. This article had its roots in conversations between Kim Hanson and myself, neighbors in family student housing, when I was a first-year and she a third-year law student at Stanford. Our children played together, and we talked around them over the back fence, encountering each other while hanging laundry, while carrying groceries in from the car. This work is in part the product of that shared work and thought. Since then, Kim has litigated for a major law firm, started her own firm, become known as a battered women's advocate, and remarried. She has had two more babies since we first met. I hope some day she writes her own articles. Until then, I acknowledge her thought in my work as a way of acknowledging her work as part of my own.

28. These are women who talked with me or sought me out for help over the past several years. One was my next-door neighbor at Stanford; another sought me out during my second 
at some time identified themselves as battered women. ${ }^{29}$ Three of these women were Stanford Law School students or graduates; another was an undergraduate student at Stanford. One was an acquaintance in a support group. One is black, the rest are white. All but two were mothers when the violence occurred. Though our class backgrounds vary, only one was a highly educated professional before the battering incidents described, but several have acquired academic degrees since the marriages ended. The other women's voices in this paper are drawn from identified published sources.

One of these stories is my own. I do not feel like a "battered woman."30 Really, I want to say that I am not, since the phrase conjures up an image that fails to describe either my marriage or my sense of myself. It is a difficult claim to make for several reasons: the gap between my self-perceived competence and strength and my own image of battered women, the inevitable attendant loss of my own denial of painful experience, and the certainty that the listener cannot hear such a claim without filtering it through a variety of derogatory stereotypes. ${ }^{31}$ However, the definitions of battered women have broad contours, ${ }^{32}$ at least some of which encompass my experience and the experiences of the other strong, capable women whose stories are included here.

In fact, women often emphasize that they do not fit their own stereotypes of the battered woman:

The first thing I would tell you is that very little happened. I am not one of those women who stayed and stayed to be beaten. It is very important to me not to be mistaken for one of them, I wouldn't take it. Besides, I never wanted to be the one who tells you what it was really like.

The rejection of stereotypes, the fear of being identified with these ste-

year of law school, six months after I gave a talk for incoming women students about emotional reactions to the materials in casebooks. When I relate these women's stories, I do not include specific citations.

29. Most did not generally use the term when describing themselves.

30. See infra text accompanying notes 86-92 (this term labels the woman instead of the process or the man), and infra note 93 . I would prefer some term that lets us discuss stereotyping without hopelessly dooming the discourse from the start. However, I think it is important to overcome our fear of the stigma and stereotype that come with the term "battered woman," so I accept it for this paper.

31. I fear derogatory stereotypes of myself and of my ex-husband and of that marriage. See generally infra text accompanying notes 86-93; see also Liz Kelly, How Women Define Their Experiences of Violence, in FEMINIST PERSPECTIVEs ON WIFE ABUSE 114, 116 (Kersti Yllo \& Michele Bograd eds., 1988) (meaning of terms like "rape" and "battering" often taken for granted).

32. See infra text accompanying notes $110-36$ (critique of definitions of battering and battered women). 
reotypes, is expressed by lesbian women as well as heterosexual women:

First I want you to know that $I$ am an assertive and powerful woman. I do not fit my stereotype of a battered woman. I am telling you this because I never thought it could happen to me. Most lesbians I know who have been battered impress me with their presence and strength. None of them fit my stereotype. Do not think that what happened to me could not happen to you. ${ }^{33}$

Although there is relatively little published material on lesbian battering, this literature can shed light on the ways in which we conceptualize the battering process. Although lesbian battering is similar to heterosexual battering, the analysis of lesbian battering is unique in two ways that are significant for this paper: it has been generated entirely by feminist activists, and it has developed in isolation from the legal system. Therefore, it provides one clue to the question, "[W] would this ... landscape look like if women had constructed it for ourselves?"34

Part I of this article discusses violence in the ordinary lives of women, describing individual and societal denial that pretends domestic violence is rare when statistics show it is common, ${ }^{35}$ and describing the ways in which motherhood shapes women's experience of violence and choices in response to violence. Part II examines definitions of battering and evaluates their effectiveness at disguising or revealing the struggle for control at the heart of the battering process. I then describe in Part III the pressures that self-defense and custody cases place on legal and cultural images of battered women and contrast the development of an analysis of lesbian battering, an analysis generated outside the legal system. In Part IV, I discuss battering as a struggle for power and control and show how legal analysis can help reveal the control issue by naming separation assault and building litigation

33. Arlene Istar, The Healing Comes Slowly, in NAMING the VIOlence: Speaking OUT About Lesbian Battering 163, 164 (Kerry Lobel ed., 1986) [hereinafter NAMING THE VIOLENCE].

34. Christine A. Littleton, Women's Experience and the Problem of Transition: Perspectives on Male Battering of Women, 1989 U. CHI. LEGAL F. 23, 30 (1989) (paraphrasing Heather R. Wishik, To Question Everything: The Inquiries of Feminist Jurisprudence, 1 BERKELEY WOMEN's L.J. 64, 75 (1985) ("In an ideal world, what would this woman's life situation look like, and what relationship, if any, would the law have to this future life situation?")).

35. Denial is a potent force that operates on at least four levels: at a broad societal level that shields the institution of marriage (we do not recognize the pervasiveness of violence and its normal occurrence within marriage), among men who wish to protect their privilege or deny their own battering, among individual women who are not currently battered or who believe they are not ("I wouldn't be like that"), and in women who admit experiencing domestic violence but minimize their estimates of its harm to themselves as part of survival and coping mechanisms. See generally infra text accompanying notes 47-73. 
strategies to redefine the issue separation. Finally, in Part V, I identify separation assault in the cases where women have been killed or harmed, as well as cases in which women killed in self-defense, and explain how the concept of separation assault is consistent with the particular needs of expert testimony in the self-defense cases. I demonstrate how naming separation assault can intervene in the interrelationship between law and culture in the field of domestic violence to change both the questions asked and the answers found by courts in several areas of law.

\section{VIOLENCE AND THE ORDINARY LIVES OF WOMEN}

\section{A. The Prevalence of Violence and the Phenomenon of Denial}

Most people I have known who have been abused in marriage have come out - once burned, twice shy. But that doesn't mean fire's not hot. But people treat marriage and relationships and love, in our society, as if fire's not hot.

Statistics show that domestic violence is extremely widespread in American society. Exact figures on its incidence are difficult to come by. Some studies have counted incidents of violence by or against either spouse regardless of context and found a nearly equal incidence of violence by men and women. ${ }^{36}$ Other studies show that women are far more frequently victimized than men, ${ }^{37}$ and that women's violence is almost always in self-defense and generally less severe than their partner's. ${ }^{38}$ The most conservative figures estimate that women are physically abused in twelve percent of all marriages, ${ }^{39}$ and some scholars estimate that as many as fifty percent $t^{40}$ or more ${ }^{41}$ of all women will

36. Murray A. Straus et al., Behind Closed Doors: Violence in the American FAMILY (1980).

37. In New Jersey, wives or girlfriends were victims in $85 \%$ of all reported domestic violent offenses. Gail A. Goolkasian, Confronting Domestic Violence: A Guide for Criminal Justice Agencies, in U.S. DEPT. OF JUSTICE REP. (1986).

38. Daniel G. Saunders, Wife Abuse, Husband Abuse, or Mutual Combat? A Feminist Perspective on the Empirical Findings, in Feminist PERSPECTIVES ON WIFE ABUSE, supra note 31, at $90,103-08$.

39. STRAUS ET AL., supra note 36 , at 36.

40. LENORE WALKER, THE BATTERED WOMAN 19 (1979) [hereinafter LENORE WALKER]. The 50\% estimate is weighed and accepted by Christine A. Littleton. Littleton, supra note 34, at $28 \mathrm{n} .19$. For the reasons articulated by Littleton, and from the stories told to me by women, the $50 \%$ figure seems reasonable to me as well.

41. JenNifer B. Fleming, Stopping Wife Abuse 155 (1979), quoted in Achieving Equal Justice for Victims of Domestic Violence, in ADVISORY COMM. ON GENDER BIAS IN THE Courts, California Judicial Council, ACHIEving EQual Justice for Women and MEN IN THE COURTs pt. 6, at 3 (draft Mar. 23, 1990) [hereinafter Achieving Equal Justice] (estimating $60 \%$ of married women experience domestic violence at some time during their marriages); SisTerhoOd Is GLOBAL, 703 (Robin Morgan ed., 1984) (50\%-70\% of women experience battering during marriage). 
be battering victims at some point in their lives. Accurate estimates are difficult, ${ }^{42}$ in part because of the likelihood of underreporting. ${ }^{43}$ However, using any of these estimates, marriages that include violence against the woman represent a relatively widespread phenomenon in our society. ${ }^{44}$

Although these statistics are widely reproduced, there is little social or legal recognition that domestic violence has touched the lives of many people in this society and must be known to many people. Judicial opinions, for example, treat domestic violence as aberrant and unusual: "a unique and almost mysterious area of human response and behavior," 45 "beyond the ken of the average lay [person]." 46 This radical discrepancy between the "mysterious" character of domestic violence and repeatedly gathered statistics reflects massive denial throughout society and the legal system.

Denial is a defense mechanism well recognized in psychology that protects people from consciously knowing things they cannot bear to reckon with at the time. ${ }^{47} \mathrm{~A}$ powerful if undiscussed force affecting

42. The incidence of domestic violence is hard to determine, in part because it takes place within the home, and in part because the many studies in the field present statistical information that is not directly comparable with that in other studies. Some focus on the number of women who are victims of spouse abuse: estimates of women physically abused by husbands or boyfriends in the United States range from 1.5 million, BROWNE, supra note 3, at 5, to 3-4 million, Mary Pat Bryger, Domestic Violence: The Dark Side of Divorce, FAM. ADVOCATE, Summer 1990, at 48. Straus, Gelles, and Steinmetz studied violence against spouses of either gender and found that more than 1.7 million Americans at some time faced a spouse wielding a knife or gun. STRAUS ET AL., supra note 36 , at 34.

43. BroWNE, supra note 3, at 45 (citing studies by Straus, Gelles, and Steinmetz and the Louis Harris organization). Self-reports may undercount significantly. See generally DiANA E. RUSSELL, RAPE IN MARRIAGE 96-101 (1982) (reviewing statistical techniques and results of several surveys on domestic violence).

44. Stating violence is normal does not mean it is normative or culturally accepted, as it once was. See DoBASH \& DoBASH, supra note 12 , at $48-74$, for a discussion of violence that was historically part of control of women within marriage. Violence against women was an early focus of feminist protest and efforts at reform. By the mid-nineteenth century, contrary to some popular stereotypes, wifebeating was already considered "a disreputable, seamy practice"; it was illegal in most states by the 1870s. LINDA GORDON, Heroes OF THEIR OWN LIVES: THE POLITICS AND HISTORY OF FAMILY VIOLENCE 255 (1988). Although today domestic violence is indeed "disreputable," that does not mean that it has disappeared in fact - only that the commonality of its occurrence in normal marriage is widely denied.

45. See, eg., Sinns v. State, 283 S.E.2d 479, 481 (Ga. 1981) (explaining Smith v. State, 277 S.E.2d 678 (Ga. 1980)).

46. See, e.g., Ibn-Tamas v. United States, 407 A.2d 626, 634 (D.C. 1983).

47. The American Psychiatric Association defines denial as "[a] defense mechanism operating unconsciously used to resolve emotional conflict and allay anxiety by disavowing thoughts, feelings, wishes, needs, or external reality factors that are consciously intolerable." AMERICAN Psychiatric Assn., A Psychiatric Glossary 28 (5th ed. 1980). The emphasis here is on what is consciously tolerable for an individual. This is the sense in which I use the term "individual denial." I use the term "societal denial" to mean an ideology that protects us from knowing that which our culture finds intolerable. Cf. David M. Trubek, Where the Action Is: Critical Legal Studies and Empiricism, 36 STAN. L. REV. 575, 607 (1984) ("Legal thought is a form of 
the evolution of the law and litigation on battered women, denial exists at both the societal and individual levels. Societal denial amounts to an ideology 48 that protects the institution of marriage by perpetuating the focus on individual violent actors, concealing both the commonality of violence in marriage and the ways in which state and society participate in the subordination of women.

"Societal" denial - albeit within a smaller, more consciously selfdefined society - also slowed recognition of lesbian battering. Although many lesbian activists helped start the battered women's movement, battering did not emerge as an internal problem in the consciousness of the lesbian community until years after the movement had begun. ${ }^{49}$ This collective denial of internal violence was based, in part, on the reluctance to let go of an ideal of lesbian relationships and community, a "lesbian utopia - a nonviolent, fairly androgynous, often separatist community struggling for social justice and freedom for ourselves and other oppressed people."so

However, there are important differences between the ideological defense of marriage and the defense of lesbian utopia. The differences lie in the way power is vested in one partner of a marriage at the time of marriage by society, law, and tradition, fitting heterosexual battering into a historic framework of oppression and domination of women by men. Marriage is an institution which underlies many perhaps most - other social, political, and economic relations, and to that end many elements of society have a stake in defending it. Because of oppression of lesbians and exclusion from many social structures - for example, lesbians cannot marry in the United States - the dream at stake was less central to the surrounding society but, poignantly, at least equally central to lesbian self-definition and community.

The ideology that protects the institution of marriage and the state's participation in subordinating women is consistent with the findings of James Ptacek's study of batterers. ${ }^{\text {s1 }}$ Ptacek found that

denial, a way to deal with perceived contradictions that are too painful for us to hold in consciousness.").

48. JURGEN HABermas, KNOWledge ANd HuMAN INTERESTS 311 (Jeremy J. Shapiro trans., 1971), quoted in James Ptacek, Why Do Men Batter Their Wives?, in FEMINIST PERSPECTIVES ON WIFE ABUSE, supra note 31, at 155 ("From everyday experiences we know that idens serve often enough to furnish our actions with justifying motives in place of the real ones. What is called rationalization at this level is called ideology at the level of collective action.").

49. See, e.g., Lydia Walker, Battered Women's Shelters and Work with Battered Lesbians, in NAMING THE VIOLENCE, supra note 33, at 73 (describing her work in a battered women's project, her work with battered lesbians, and her difficulty in facing the violence she had experienced in her own relationships with women).

50. Barbara Hart, Preface to NAming the Violence, supra note 33, at 9, 13.

51. See generally Ptacek, supra note 48. A New York judge told the state's Task Force on Women in the Courts that, when a woman gives up an attempt to separate, judges either smile 
both batterers and the criminal justice system tended to blame women for their abuse and deny or trivialize the violence involved. ${ }^{52}$ These excuses and justifications are ideological in nature: "At the individual level, they obscure the batterer's self-interest in acting violently; at the societal level, they mask the male domination underlying violence against women. Clinical and criminal justice responses to battering are revealed as ideological in the light of their collusion with batterers' rationalizations."53

This ideology pervades the courtroom as well as other areas of the criminal justice system. It shapes legal events in several ways: it affects the individual consciousness of the actors in the courtroom, ${ }^{54}$ the doctrinal questions that are the legal framework of each action, ${ }^{55}$ and the options to avoid legal confrontation and the resources individuals bring into the courtroom. ${ }^{56}$ Especially troublesome, this ideology which denies oppression has had a profound impact on the development of explanations of women's experience and behavior that can fit within the conceptual structure of the law. ${ }^{57}$

It is likely that a number of people present in any court will have some personal experience of domestic violence. ${ }^{58}$ Using the conservative estimate that domestic violence occurs in one quarter of house-

(thinking they have brought the couple back together), or snicker. The snickering response is based on their perception "that the woman who accepts this violent behavior and reconciles with the man[] even if she reconciles in a split but doesn't pursue the case, isn't worthy of our respect because she does not respect herself ...." New York Task Force on Women in the Courts, Report of the New York Task Force on Women in the Courts, 15 FORDHAM URB. L.J. 11, 36-37 (1986-1987) [hereinafter New York Task Force Report].

52. Ptacek, supra note 48, at 141-49 (batterers), 154-55 (criminal justice system).

53. Id. at 155 (emphasis added).

54. See infra text accompanying notes 58-61 (discussing experience of battering among courtroom participants).

55. See, eg., infra text accompanying notes 371-78, 410-24 (discussing the question of the imminent danger of death or grave bodily harm in cases in which women assert they have killed their batterers in self-defense).

56. See, eg., infra text accompanying notes 195-210 (discussing the relative power of men and women in custody actions).

57. For example, if the batterers' position is essentially identical with the perspective of the criminal justice system, and both fit with an ideology that protects marriage, then the "commonsense" position in any courtroom will tend to favor men. Therefore, women will need experts to explain their lives; men will not. See, e.g., Littleton, supra note 34, at 35 (all women, not only battered women, may appear alien from a male perspective).

58. Violence in our personal lives has existed for everyone in varying degrees. The magnitude of the damage and turmoil is the real crux of the problem. If individuals on the panel are afraid of their own feelings about having been battered, then perhaps they will not be open to the battered woman's feelings. Some will have battered someone themselves and will struggle to justify their own actions.

Roberta K. Thyfault et al., Battered Women in Court: Jury and Trial Consultants and Expert Witnesses, in Domestic Violence on Trial: Psychological and legal Dimensions of FAMILY VIOLENCE 55, 62 (Daniel J. Sonkin ed., 1987) [hereinafter DoMESTIC VIOLENCE ON TRIAL]. 
holds, 59 at least four of the fifteen or more actors in an average criminal action - jurors, judge, and attorneys - probably will have experienced or committed at least one domestic assault. 60 Similarly, in custody suits, the judge and the attorneys - and the social workers and psychologists who are performing evaluations of the parents have this statistical likelihood of having experienced or committed violence. Therefore, the atmosphere in the courtroom will not reflect mere ignorance, nor merely the broad social stereotypes which courts generally recognize can be a problem. ${ }^{61}$ Rather, the response to and evaluation of the case before them will also include the unseen and unspoken ties that bind these participants to the fabric of their own lives, their parents' lives, and their children's.

Social workers and psychologists play an important role in this process. Our legal system - like the rest of society - has to a large extent entrusted these professionals with the definition of what is normal and functional. ${ }^{62}$ Despite the statistics on the epidemic incidence of domestic violence, there is almost no legal or social science scholarship that describes an author's experience of violence ${ }^{63}$ or even indicates that the author has had any such experience. ${ }^{64}$ It is unlikely that a disinterested body of social scientists is doing all this research. However, scholars may be reluctant to indicate their own experience because they fear intellectual marginalization ${ }^{65}$ or familial repercussions. Scholarly fears of marginalization probably reflect some acceptance of stereotypes of battered women; certainly, they reflect caution about the power and danger of stereotyping by others.

This silence among professionals and scholars is one intersection between individual denial and an ideology of societal denial. This is where one of the lenses through which we see the world is constructed:

59. See supra notes $36-44$ and accompanying text.

60. Overrepresentation of the middle class in the courtroom would not change this estimate. Domestic violence occurs across class lines. LENORE WALKER, supra note 40, at 19.

61. See, e.g., State v. Kelly, 478 A.2d 364, 378 (N.J. 1984) (jurors may hold "common myths").

62. See, e.g., infra text accompanying notes 213-22 (discussing the role of social workers in custody disputes).

63. The exceptions here are Robin West, who discusses her own experience of battering, Robin L. West, The Difference in Women's Hedonic Lives: A Phenomenological Critique of Feminist Legal Theory, 3 WIS. WoMEN's L.J. 81, 98-99 (1987); and Terry Davidson, who discusses being the child of a wife beater, TERRY DaVIDSON, ConJUGAl CRIME: UNDERSTANDING AND Changing the Wifebeating Pattern 14-15, 131-54 (1978).

64. But see Jan E. Stets' preface to her excellent study, JAN E. STETS, Domestic Violence AND CONTROL v (1988) (research on domestic violence brought understanding of violence she witnessed and experienced while growing up).

65. See, e.g., West, supra note 63, at 99 (describes grappling with this anxiety but goes on to discuss her own experience). 
if scholars are silent for "personal" reasons, their "professional" silence then perpetuates the social stereotypes that construct battered women as different, exceptional, "other." Ultimately, the denial of personal experience of domestic violence in social science literature and forensic testimony permits continued societal blindness to the implications of the statistics these same experts gather and employ. ${ }^{66}$

Individual denial protects the images of self and marriage held by individual women and men, as well as being the mechanism through which much societal denial operates. This is true elsewhere as it is in the courtroom: people need to know that their own marriages are sound, therefore it is important to know that they (or their wives) do not "stay" in the relationship; they "are" in the relationship. Their own relationships define what is normal and appropriate; it is appropriate for their own relationships to continue. The battered woman must be different. Therefore, the question "why did she stay?" commonly finds answers that attempt to explain difference: "because she had children" or "because she was frightened" or "because she became pathologically helpless" - not, significantly, because $\mathrm{I} /$ you/we "stayed" too.

Do we "stay," or are we simply married? Writing this article forced me to grapple with my own image of battered women, my "credentials" in claiming this identity, and my experience of marriage. As I worked, I found similar conceptions of self and marriage in several of the women who spoke with me. These women described their marriages as "bad" or "unhappy" and then went on to recount attacks that were almost murderous - threats with guns and knives, partial strangling, deliberately running into a woman with a car:

I tried to nurse John [her colicky baby], but Ed screamed that I was trying to poison him. I said, "OK, I'll get you a bottle." I had to kneel down by the microwave, and Ed pushed me over, so that I fell over. So I put the bottle in the micro and stood up, and finished microwaving the bottle, put the nipple on, and gave it to Ed. . . . Ed began screaming almost incoherently, and grabbed John, and started to storm back out to the car with him.

At this point I got worried. The first time [earlier that night, when her husband first stormed out and drove around with the baby] I thought he was angry because I had yelled, and I felt guilty ... it didn't seem that aberrant. But screaming about poison when I tried to nurse him, knocking me over ... . it just seemed like there was something wrong. I said, "You're welcome to leave, but you can't take John. I don't think you're all there." 
He pushed past. I stood in front of the car. He drove into me. I tried to go over the hood of the car, hit the pavement quite hard, and blacked out for a minute. When I came to, he had turned the car around, he was like a foot from me, and he was saying "get up, or I'll drive over you."

[Her husband had "scared himself ... realized he had gone too far" and gave her the baby to nurse. They finally fell asleep.] Next morning, Ed had gone to work. I couldn't move, I couldn't move my legs. I remember thinking, I'm going to die. [The baby] is going to wake up next to a corpse .... When I look back, there was so much rage in that thought [at the colicky baby as well as the husband] .... I had a very hard time functioning. I was able to make it to the bathroom, but the tunnel vision seemed worse.

Women often discussed the relationship at length before they mentioned any violence. Finally, I began to understand that the violence against these women seemed shocking to me - and the violence against me seemed shocking to them - precisely because we heard each others' reports of violence isolated from the context of the marriages. For ourselves, on the other hand, the daily reality of the marriages - none of which included daily or even weekly violent episodes - defined most of our memories and retrospective sense of the relationship: these were "bad" marriages, not ordeals of physical torture. We resisted defining the entire experience of marriage by the episodes of violence that had marked the relationship's lowest points. Our understanding of marriage, love, and commitment in our own lives - as well as our stereotypes of battered women - shaped our discussion.

This question of the line between "normal" marriage and violent marriage is a common one. One activist social worker recounts that when she speaks on domestic violence in any forum, someone always asks why women "stay." She says, "When should she have left? At what point? Maybe the time she watched while he smashed up the furniture?" A silence, a shock of recognition, falls over the audience. It is, relatively speaking, normal for a woman to watch a man smash up the furniture. Many of the women in the room have seen something like it - and called it "marriage," and not "staying."67

Denial conditions women's perceptions of our own relationships and need for assistance. An extreme example is a woman who founded a shelter for battered women; although her husband was beating her during this period, she never identified with the women she sought to help:

I just thought that the incidents of violence that $I-$ in order to be a

67. Conversation with Donna Coker, 1989 (discussing four years of activist feminist social work with battered women in Honolulu). 
battered woman you had to be really battered. I mean OK, I had a couple of bad incidents, but mostly it was pretty minor, in inverted commas, "violence." I didn't see myself in that category, as a battered woman at all. ${ }^{68}$

Similarly, women may fail to perceive armed attacks that do not result in injury as physical abuse - or indeed fail to so perceive anything other than an archetypal brutal beating:

I don't know what I'd have done if I had to live with what [I assume] you did. My marriage wasn't physically abusive, but there was emotional abuse. My husband had a pistol ... he did pull his gun on me ....

This may happen even when the woman calls for help:

When I finally called the Battered Women's Center for help, I was just looking for advice - my husband had threatened to move back in without my consent while I was recovering from a Cesarian section .... He said "you can't stop me" ... . I told the counselor that I was just looking for a referral, as I didn't qualify for their help because my marriage had not been violent, although I had left after he attacked me with a loaded shotgun. There was a tiny pause, and then she said gently: "We classify that as extreme violence."

Other aspects of women's denial of oppression within ordinary marriage also affect our perception of battered women. Battered women interviewed by social workers often say they felt a responsibility to support their children's relationship with their father because "he's really good with the children."69 This is not dissimilar to statements by women in nonviolent relationships - or relationships they do not perceive as violent. Women often admit when pressed that they are actually describing a father who is loving with a child when he chooses to interact with it, even if that interaction happens seldom, yet insist on the value of his presence in the children's lives. However, this is a parallel that makes many women uncomfortable: how could a batterer be like their husband? Similarly, although sexual abuse is often a part of domestic violence, many battered women who did not experience sexual abuse describe sex as having been "the only good thing about the marriage."70 Women who are in relationships of unequal power that are not violent must also find sexual pleasure under conditions of inequality, yet they may not wish to recognize the similarity in experience.

68. Kelly, supra note 31 , at 114, 123-24.

69. Conversation with Donna Coker, supra note 67.

70. Id; see also Lenore Walker's discussion of her difficulty understanding the reports of sexual pleasure among the battered women she interviewed. LENORE WALKER, supra note 40, at 108-12. 
The literature on battering notes, clinically and sometimes with condescending undertones, that women tend to "perceive" the onset of violence as atypical. ${ }^{71}$ Of course, the onset of violence is atypical, and therefore our perceptions are in many ways appropriate. ${ }^{72}$ Yet we may ignore danger signals and early attacks because we believe that the "battered-ness" is a characteristic of the woman - a characteristic we do not have - rather than a characteristic of her partner or a symptom of a dynamic in the relationship. Denial creates and reinforces the perceptions (1) that battered women are weak, (2) that we are not weak, and (3) that therefore we are safe.

Finally, individual denial leads women to minimize the pain and oppressiveness of our experiences while we continue to live with them. This is also a familiar dynamic in women's relationships; yet if violence is what we are minimizing, we face great costs and dangers.

That session in the hospital when I had been married one month, and the nurse came and sat on the bed and said she had heard I didn't care if I went home for Christmas . . . . The truth was, I couldn't face what I was going home to. I instinctively knew it was very bad to lie about this but I couldn't bear to tell the truth. It was too humiliating. I didn't tell her anything. To my friends, I said I fell down. I did not intend to cover for him but for myself . . . for the confusion and humiliation . . . for finding myself in this unbelievable position.

This woman's images of battered women and herself make her position "unbelievable." Her response, based on these images, is to disguise her experience. She allows her husband to avoid the censure of family and friends in order to protect herself from their opinions, setting up the possibility of more such lies in the future because the image itself has not been confronted, and making it likely that she will minimize her own pain in order to maintain silence. ${ }^{73}$

The cumulative effect of this denial has been very destructive for women. We have difficulty recognizing ourselves and our experience on the continuum of violence and power in which we actually live. To the extent that we cannot recognize ourselves, we are hindered in for-

\section{BRowne, supra note 3 , at 85 .}

72. The initial violent episode is not treated as though it signals the beginning of a violent relationship. It is treated as an isolated, exceptional event, which is what one would expect it to be treated as. Only in retrospect does the woman begin to examine the first violent act more broadly, seeking signs that "she should have noticed..." The evidence is that there has never been any violence before, that the husband rejects this behavior in principle. ... There is no reason to expect the violence to be repeated.

DOBASH \& DOBash, supra note 12 , at $95-96$.

73. Battered women tend to minimize the history of assault against them and the pain they have suffered. See Julie Blackman, Potential Uses for Expert Testimony: Ideas Toward the Representation of Battered Women Who Kill, 9 WOMEN's RTS. L. REP. 227, 228-29 (1986). 
mulating an affirmative vision in which our integrity is protected. Although much of this article emphasizes legal aspects of the related forces of law, society, and academia at work in the field of battered women, I believe that the ways in which women are divided from each other - and deprived of the capacity to understand our own experience in relation to other women - are ultimately most important.

\section{B. Motherhood: Connectedness and Violence Against Women}

Look at me, a voodoo doll, stuffed with hair, toenails, and fear, stuck with pins radiating like hatred from my pincushion body. You've held me in your hands, a wooden fetish female figure carved out of heartwood and studded with nails.

Each nail driven in is a desire, a wish, is somebody's want driven into me. ${ }^{74}$

One of the most pervasive fictions in the case law is that women with children are individual actors. Even much feminist legal literature has tended to pretend all women's notions of self and autonomy will be the same. ${ }^{75}$ In fact, mothers continually make decisions on the basis of extended, collective, multiple self-interest (their children's as well as their own, their husbands' as well as their children's). ${ }^{76}$ The connectedness of mothers is not simply biological - it is existential, social, and extremely practical. Most simply, what makes my children's lives harder makes my life harder. If they are ill or sleepless, I do not sleep. ${ }^{77}$ It goes both ways: what hurts me, or terrorizes me, often hurts them as well. Also, anything that made their father's life harder made my life harder, in both emotional and economic dimensions. Finally, as the safest outlet for emotional expression and the source of consolation for our unequal loved ones of greater or lesser

74. Harryette Mullen, Veteran of Domestic Wars, in FAMuly VIOLENCE: PoEMS ON THE Pathology, supra note 1 , at 51.

75. See generally Stephanie Wildman, The Power of Women, 2 YALE J.L. \& FEMINISM 435 (1990) (book review) (criticizing Catharine Mackinnon and other feminist scholars for their inattention to the particular situations of women with children).

76. On women's intimate connection with our families, and the identity built on this connection, see generally Robin West, Jurisprudence and Gender, 55 U. CHI. L. REV. 1, 18-22, 40 (1988).

77. I do not mean that these roles are purely biologically defined. To the extent that some men fill this role with children, they can be seen as also engaged in mothering. Christine Littleton has pointed out that gender is in many ways socially constituted. Christine A. Littleton, Reconstructing Sexual Equality, 75 CAL. L. REv. 1279 (1987). Men who interact at this primal caregiving level with their children are carrying out conduct Littleton calls "socially female." Id. at 1308-09. 
power, ${ }^{78}$ women are uniquely bound to weighing the needs of others as our own. These needs have, in fact, become our own in many significant ways - our "selves" simply are not single.

The ordinary lives of women leave us vulnerable to violence and oppression both because of our commitments and because of the lack of understanding and protection within the law. Despite the many responsibilities and connections of women's lives, courts and legal scholars widely assume that it is a woman's responsibility to leave the relationship. ${ }^{79}$ When women tell the stories of their commitment to relationships, stories which may include love and hope, the legal system often has no way to hear them. ${ }^{80}$ In order to recognize women's attempts to forge families and the complex attendant pressures on decisions about domestic violence, we need to increase social understanding of women's commitments as well as of women's fear. In fact, the onset of violence often occurs after commitment deepens. This may occur soon after the couple is married:

He beat me up on our wedding night. I wound up with a black eye, a very bad black eye, and split lip. He was almost arrested that night .... I ran out of the house in my nightgown and flagged down a passing car and got them to take me to my father-in-law's house. When my fatherin-law came back, the neighbors had called the police and the police were there. My father-in-law talked them out of taking him in.

Pregnancy, which also increases commitment, is also often an onset point for violence. ${ }^{81}$ Women who experience this violence have had their emotional and economic needs transformed by the pregnancy itself; it is a very poor time for them to respond. Since mothers bear much of the responsibility for the emotional ties between the fathers and children in our society, the new family structure changes her responsibilities to all parties: if the children are not physically

78. See West, supra note 76 , at 26 (women exist in a web of natural inequality that involven continual care for dependent children).

79. This assumption is questioned by Littleton, supra note 34 , at 29, 53-54 ("Why should the woman leave? It's her home, too - in fact, often it's her home, period.").

80. Id. at 43-44, 46-47 (discussing Smith v. State, 277 S.E.2d 678, (Ga. 1981)).

81. The accounts of pregnancy triggering men's violence against women are virtually universal. See, eg., LENORE WALKER, supra note 40, at 105-06. This is generally interpreted as the man's competition with the fetus for his wife's attention and affection. Id. It is true that our emotional lives and daily practical lives are transformed by children; men often want this attention, have received it, fear its loss, show resentment and anger. People who have problems with control may react badly to change and stress. See Richard A. STORDEUR \& Richard STILLE, Ending Men's Violence Against Their Partners: One Road to Peace 101-03 (1989). Interestingly, pregnancy is not on the list of stressors listed by Stordeur and Stille that therapists see most in treating batterers. This may be a function of the point in the relationship at which men enter treatment: the top stressors (divorce, marital separation, jail term, marital reconciliation) all refer to later points in the relationship than marriage or pregnancy. Id. 
harmed, the woman may hesitate to deprive the children of his companionship, even at substantial danger to herself. ${ }^{82}$ However, our social and legal doctrines increase the cost of her loyalty by viewing her attempt to fulfill this responsibility as problematic "staying" in the relationship.

From the viewpoint of the woman in a violent marriage, "staying" may look very different. One of the women in my support group was strikingly strong and serene. She worked as a legal secretary, earning a good salary for a working woman. She was attractive, intelligent, thoughtful. I simply could not reconcile this woman's presence, composure, and depth with my image of a battered woman. Finally, after a meeting, I took her aside and said, "I know this question must sound just awful, but what on earth are you doing here? You're so strong. ..." She said:

Well, my husband is an alcoholic. Things have been really bad these past few years. But we've been married thirteen years. And I have three children. For nine of those years, he was the best husband and father anyone could have asked for. The way I look at it, he has a disease. I know that when he's not drinking, he's not like this. I may have to leave. But if I do, I'm giving up on a father for the children, and I'm giving up on him. And I can't just throw away those nine years. So I go to AlAnon, and I come here. I get the support I need. And I may have to decide to go. But I'm not going to do it lightly.

The wearing, repetitious labor of motherhood becomes part of the cycle of survival in ways we have had trouble recognizing. The constant work and need create a wearing down of the self, an erosion of borders that represents not confusion but exhaustion - a thirst for solace and protection as well as individuation. The constant demands of children, especially in an unstable situation, may prove exhausting. Women experience this blurring of borders, this need to subject their own needs to others, even when violence is not present. Question: Was it a battered or nonbattered wife who wrote this poem?

82. Even after divorce, most women place high value on their children's relationship with the father. LenORe WeItzman, The Divorce Revolution 230 (1985). In fact, the woman is essentially required to be responsible to these broad familial emotional and developmental needs when she goes into court to pursue her claim to custody. Martha Fineman notes that social workers are suspicious of individuals who seek sole custody and seem to want to break ties with the other parent; social workers tend to want to punish these individuals by awarding custody to the other parent. Martha Fineman, Dominant Discourse, Professional Language, and Legal Change in Child Custody Decisionmaking, 101 HARv. L. REv. 727, 766 (1988). 


\section{A Woman's Work is Done (on the Run)}

Mama, I'm hungry

So get up and feed me my diapers are dirty it's your job to clean me.

Mama, I'm happy and I want to play

Do you really have something else to do anyway?

Mama, I'm angry and I want to fight Sometimes it seems like you can't do nothing right.

Mama, I'm hurting you gotta make me better. Cure my cold, wipe my nose and make me wear a sweater.

Mama, I'm tired so rock me off to sleep. Just give me the best of your life and don't weep.
Baby, I'm hungry you know I got to eat You've got a way w/cookin that just can't be beat.

Baby, I'm happy and I want to play A little of your love goes a long way.

Baby, I'm angry $\mathrm{cOz}$ you want your "rights" You know you're just(I) a woman so go fly a kite.

Baby, I'm hurting and need your gentle touch Just hold me close and rock me it doesn't take that much
Baby, I'm tired so let me go to sleep
Don't bother me with your needs
just make my life complete.

Answer: It was a nineteen-year-old woman in the midst of a battering relationship, ${ }^{83}$ but like the furniture smashing example above, there seems little to distinguish this woman's daily concerns from a nonviolent marriage. The skills common to women in dealing with these demands easily convert to battlefield skills of compartmentalization and an emergency mode of coping with only immediate present demands; while extremely functional in times of crisis, these skills are wearing over time and may later cause her to be defined - or to define herself - as dysfunctional.

Two days after he broke the glass in the door, it was the middle of a hot summer afternoon. My son was asleep in his crib in my room, my daughter was taking a nap in hers. I was lying in bed reading. Suddenly, I heard a popping noise, and glass started crashing to the floor. Someone was shooting through my windows. There were no bullets flying around - I remember wondering if it was an air rifle. The windows kept shattering, and I didn't know what would happen if anything hit the baby.

83. I thank Kim Hanson for sending the poems by J.C. Clark, as well as portions of her own journals I drew on extensively for this article. 
I grabbed him out of the crib, got down toward the floor, and halfcrawled out of the room. I took him downstairs. Of course, he was only three-months-old, when he woke up he had to nurse. Then I had to change his diaper. Then my daughter started crying - she had waked up from her nap. Then I had to change her diaper. Then she was hungry. Then $I$ had to change his diaper again. By then he had to nurse again ....

At 5:30 when I took them upstairs for their baths, I noticed the glass all over the floor. That was when I remembered what had happened. It was the worst moment of all of it . . . because I couldn't even rely on myself any more. I started crying and I called my mother long-distance. I said, "Mama, it finally got to me, I've finally lost my mind. If your window is shot out and you crawl out of the room with your baby in your arms, you're not supposed to forget about it. It should at least be the main event of the dayl"

Ironically, this particular attack ultimately proved to be teenage vandalism, coincidentally following by two days a violent episode in which the woman's ex-husband broke a pane of glass in her door and lay bleeding on her floor until the police arrived. She described an initial unwillingness to call the police again so soon after the previous events, and her conviction at the time that the attacks must be related. The blurring of borders, so frightening at the time, is in fact part of women's experience of motherhood and daily life - of her daily duty to lay aside her own needs for her children's. In many cases, the emotional changes of motherhood may combine with the pressures of violence to push women toward at least temporary compliance with a batterer's demands - while in the long run impelling her toward whatever choice (leaving, staying, seeking family or professional intervention) seems to best protect both herself and her children.

Finally, the sense of physical responsibility to the children - inevitably, economic responsibility - is a major constraint. Women and children suffer severe economic losses upon divorce. ${ }^{84}$ Mothers must be very desperate to walk out without knowing how they will all survive. A large number of homeless women and children today have fled violent situations, and women often balance the possible harm to the children through inadequate housing with the harm from maintaining the relationship. Unless the children are threatened directly or indirectly, the woman may well choose for them rather than herself. In a very real way, she is choosing between known and unknown dangers, blurred borders under familiar conditions and those under unfamiliar conditions.

Our building was very roach-infested. In winter, the children needed 
real shoes instead of sneakers, and I put together the money to get them good high-tops. My son's shoes had an unusually strong smell of leather. One morning I picked up his shoe and it erupted ... a volcano of baby roaches, with a few big roaches as well. They loved that shoe. Every night they tried to move in. Powder didn't help. I couldn't afford more shoes.

To me, this is what all of it was like, the marriage and what followed. I just remembered to pick up and hide the baby's shoe every night or ... remembered to get there first every morning, when he couldn't see me, and shake out the hundreds of nesting roaches. Or, because eventually it happened, I forgot, and heard him scream in terror. And felt terrible because I had failed to protect him from knowing that shoes can explode into insects, that everything can change to nightmare in a second.

Whether the woman is trying to maintain a relationship or trying to leave it, her particular life circumstances will affect the dangers she faces and the choices she makes. Women are entitled, as Christine Littleton says, to "safe connection" - to the measures that protect us in this effort as well as to social recognition of our values and needs. ${ }^{85}$ We are also entitled to legal doctrines that respect our circumstances and responsibilities by recognizing that every aspect of our experience of assault and response to it may be shaped by the experience of motherhood, including the times at which we are attacked, the nature of the attacks, the methods by which we cope, and our judgment of whether the pain of relationship outweighs its value.

\section{Definitions of BatTering AND BATtered WoMEN}

\section{A. Identification as a "Battered Woman"}

"Battered woman" is not a simple term.86 It focuses on the woman and defines her through the battering experience. While the term has some value for understanding women and our experience, both of these qualities might also reinforce stereotypical notions of women's experience. This section describes problems women encounter in identifying ourselves as "battered," the ways in which definitions of battered women reflect changing social consciousness, and the way descriptions of battering have moved from a focus on control toward a focus on incidents of violence.

85. See Littleton, supra note 34, at 49-53. "If battered women seek to maintain connection in the face of enormous danger, perhaps the key to accessing the legal system on their behalf lies in taking seriously both the connection they seek and the danger they face in that quest." Id. at 52. Littleton suggests four basic approaches: changing the batterer, decreasing the costs of rupture to women, increasing the perceived costs of battering, and expanding the options for community. Id. at 53-56.

86. See STORDEUR \& STILLE, supra note 81, at 18-20 (providing brief recent review of many positions on the terminology of "wife assault, battering, abuse, violence, family violence, and domestic violence" (emphasis in original)). 
Women resist applying the term "battered woman" to ourselves. This is often true even when we approach hotlines and shelters, ${ }^{87}$ even when we seek temporary restraining orders against our abusers, even when we talk to each other. I believe that we do this not only because of the denial discussed above, but because the stereotypical implications of the term fail to correlate with our self-images in ways that reflect correct self-assessment on our parts.

It is a deadly combination, this mixture of (negative) denial and (positive) self-respect that makes women reject an image of degradation and incapacitation. As a woman interviewed at a shelter in England said, "It's difficult to accept yourself as a 'battered wife' as the term isn't right. I have had a lot of marital troubles, which have included violence. Despite all my attempts to make the marriage work, I had no choice but to get away."88 She defines herself as active, working to solve her problems, reaching out for solutions. ${ }^{89}$ These actions conflict with her sense of what a "battered wife" is. Yet her story told of frequent beatings and otherwise fit the stereotypical picture of a battering relationship reasonably well.90 Her self-esteem and insistence on her own competency may have been double-edged: a woman's rejection of the stereotype may slow her perception of her problems or available resources, or postpone her decision to seek help, since she may not turn immediately to agencies targeting "battered women."

Because the term "battered woman" focuses on the woman in a violent relationship rather than the man or the battering process, it creates a tendency to see the woman as the problem. There are other options: at one conference, several women described themselves with the phrase "a woman who used to be married to a battering man."91 However, many feminists insist on using "battered woman" in preference to terms such as "spouse abuse" which are not gender specific in order to emphasize that women, not men, are almost always the target of intraspousal abuse. ${ }^{92}$ The very substantial psychic damage done

87. Conversation with Donna Coker, supra note 67 (recounting stories of several clients at a battered woman's program who doubted whether they were "really" battered women).

88. Joy Melville, Some Violent Families, in VIOLENCE AND THE FAMILY 10 (J.P. Martin ed., 1978).

89. Id. at $10-11$.

90. This woman had been hit frequently. Her husband did not permit her to leave the house, even to go to social security or the doctor. Id. at 11 .

91. Conversation with Donna Coker, supra note 67.

92. Studies that equated all forms of violence by all actors, whether or not provoked, have generated concern for "battered husbands." This methodology has been extensively criticized. See RUSSELL, supra note 43, at 102-09. Debate on this point continues. See generally 11 RESPONSE TO THE VICTIMIZATION OF WOMEN AND ChILDREN No. 3 (1988); Susan Schechter, 
through the experience of violence may be minimized or denied through less woman-focused terminology. Although the term "battered woman" is unfortunate in its potential for stigma, no less specific term can capture this damage; the search for different language may lose a sense of the harm..$^{93}$

\section{B. Evolution of The Definition of the Problem}

The current debate over terminology reflects differences in the backgrounds and approaches of feminist activists, scholars in sociology and psychology (some feminist, some not), and professionals such as social workers active in the field of domestic violence. Social awareness of violence against women grew out of the activism of the feminist movement of the late 1960s and early 1970s. In Women and Male Violence, Susan Schechter traces the evolution of the "women's rights" and "women's liberation" wings of the feminist movement and places the roots of public consciousness of domestic violence in the early women's liberation literature. ${ }^{94}$ Other groups were also active in the field. Women from Al-Anon, the organization for families of alcoholics, founded the first shelters for battered women in the 1960s.95 The first Boston shelter was also a self-help project: two battered women opened their home as a haven and rapidly found support from radical feminists. ${ }^{96}$

Social workers had dealt extensively with battered women since the early days of social service agencies. Over time, historian Linda Gordon has shown, women clients began to create out of their own complaints a right not to be beaten. ${ }^{97}$ Until the 1930s, the women were more likely to receive social work assistance for their charges of nonsupport by husbands than for charges of brutality; however, from

Building Bridges Between Activists, Professionals, and Researchers, in FEMINIST PERSPECTIVES ON WIFE ABUSE, supra note 31, at 299.

93. Conversation with Kim Hanson, supra note 66. We need definitions that do not inherently blame women. For the past decade, I have often reluctantly applied the term to myself in order to help break down stereotypes and overcome the strong pressures toward silence. To the extent that I do not "really" feel like a battered woman but like a bit of an imposter, I know this puts $m e$ in line with battered women everywhere. For the similar perspective of a woman who chose to use the terms "batterer" and "battered" when she had been violently struck once by her partner, see Bell hooks, TAIKING BaCK: Thinking Feminist, ThINKING BlaCK 88 (1989).

94. SUSAN SCHECHTER, WOMEN AND MALE VIOLENCE 32-33 (1982) (citing the anthology SISTERHOOD Is POWERFUL (Robin Morgan ed., 1970) and the discussion in consciousness-raising groups). Schechter reviews the different ideologies within the women's movement that contributed to the battered women's movement.

95. The Al-Anon women were concerned that women who fled abusive alcoholic husbands were sleeping in cars. $I d$. at $5,55-57$.

96. Schechter, supro note 92 , at 302.

97. GoRDON, supra note 44 , at 257-61. 
the 1930s on, women increasingly insisted on their right to physical integrity. ${ }^{98}$ Heavily influenced by Freudian thought, social workers in the 1940s and 1950s were likely to interpret women's complaints as indicating frigidity or a need to undermine their husbands' authority. ${ }^{99}$ This victim-blaming mentality contributed to family violence becoming less visible until the new emphasis and political mobilization grew out of the feminist movement of the 1970 s. ${ }^{100}$

Recently, several feminists have written about the split between social scientists and feminist activists on domestic violence issues. ${ }^{101}$ Some psychological and sociological studies of domestic violence are deeply antiwoman. Most of the early studies focused on the psychopathology of the female victims, not the aggressors; ${ }^{102}$ such approaches tended to reinforce batterers' defenses and denial, since the psychiatric problems under consideration appeared outside their control. ${ }^{103}$ Although some studies of domestic violence focus on the oppressive societal structures that vest power in men, ${ }^{104}$ those written from the family systems perspective most widespread in social work today ${ }^{105}$ tend to portray the partners as equally responsible for violence ${ }^{106}$ and ask the woman who describes experiencing violent attacks to consider how she provoked them. ${ }^{107}$ The gender-neutral approach adopted by many sociologists minimizes the importance of male domination and power. Division between activists and professionals, social scientists and funding sources has also affected how issues were explored and what research was conducted in the field of domestic violence, ${ }^{108}$ since

\section{Id. at 258-59.}

99. Id. at 282.

100. Id. at 22-25.

101. Michele Bograd, Feminist Perspectives on Wife Abuse: An Introduction, in Feminist PeRSPECTIVES ON WIFE ABUSE, supra note 31, at 11, 19; Schechter, supra note 92, at 299; Kersti Yllo, Political and Methodological Debates in Wife Abuse Research, in FEMINIST Perspectives ON WIFE ABUSE, supra note 31; see also DOBASH \& DOBASH, supra note 12, at 193-99; GONDOLF \& FISHER, supra note 12, at 1-2; Edward W. Gondolf, The State of the Debate: $A$ Review Essay on Woman Battering, 11 RESPONSE TO THE VICTIMIZATION OF WOMEN AND ChILdRen No. 3, supra note 92, at 3-8; cf. Lee Ann Hoff, Collaborative Feminist Research and the Myth of Objectivity, in FEMINIST PersPectives ON WIFE ABUSE, supra note 31, at 269.

102. Mildred D. Pagelow, Woman-Battering: Victims and Their EXPERIENCE 20 (1981) (citing several studies).

103. STORDEUR \& STILIE, supra note 81 , at 24-25.

104. See generally DOBASH \& DoBaSH, supra note 12 (discussing wife beating that is consistently placed in the context of a critique of both patriarchy and capitalism).

105. Fineman, supra note 82, at 744 \& n.77.

106. See generally Michele Bograd, Family Systems Approaches to Wife Battering: A Feminist Critique, 54 AM. J. ORTHOPSYCHIATRY 558-68 (1984) (family systems theories can perpetuate gender bias by blaming the victims of wife abuse).

107. STORDEUR \& STILLE, supra note 81, at 26; see also LEWIS OKUN, WOMAN ABUSE:

FACTS RePLACING MYTHS 96-97 (1986) (dicussing Straus' application of systems theory).

108. Feminist activists first raised the issues of wife beating as part of their struggle against 
conscious use of feminist methodology in research is rare. ${ }^{109}$ Our conceptions of battering reflect this mixed intellectual and political background.

\section{The Attempt To Define the Battered Woman}

The most widely known definitions of battering tend to be incident-focused, looking to the types of assaultive or coercive incidents and the number of times these occurred. This makes it possible to bring a woman and her history into court with objective indicia of her status as a battered woman. However, this type of definition tends to direct attention away from the source of the violence - the struggle for power and control - and has the additional problem of emphasizing the very incidents women tend to minimize and fortifying an image women seek to deny.

Lenore Walker, author of three books and many articles on battered women, is also one of the leading forensic psychologists in the field.110 By 1986, she had introduced expert testimony on battered woman syndrome in sixty-five cases in which battered women had killed or hurt their abusers. ${ }^{111}$ In Walker's first book, her definition of "battered woman" emphasized the batterer's control of the woman: "A battered woman is a woman who is repeatedly subjected to any forceful physical or psychological behavior by a man in order to coerce her to do something he wants her to do without any concern for her rights." 112 However, the very next sentence moves from a focus on control to the issue of repetition of violence and whether the woman has remained in the relationship:

Battered women include wives or women in any form of intimate

the oppression of women; professionals, researchers, and funding sources then recast and transformed the way these issues were seen and developed, casting shelter residents and program participants as "clients" rather than inclusively defining them as experiencing an extreme form of oppression faced by all women. Schechter, supra note 92 , at 302. Schechter believes the differences between activists and professionals are growing more complicated as "more professionally trained women join the movement at the same time that more battered women try to assume power within it." Id. at 309.

109. For a general discussion, see descriptions of applied feminist methodology in Hoff, supra note 101, at 270-77 (describing process of developing questions and focus for research through helping and working with the women she would study until they trusted and spoke with her, before developing her questions, thus overcoming severe mistrust of academics and professionals among shelter staff and residents).

110. See, e.g., LENORE WALKER, supra note 40; LENORE E. WALKer, THE BATTEREd WoMAN SYNDROME (1984) [hereinafter WALKER, SYNDROME]; WALKER, supra note 11. Walker's description of a three-stage cycle of battering and application of the psychosocial theory of learned helplessness to battered women had great influence on the field of domestic violence and proved especially significant in law.

111. Walker, supra note 10 , at 224.

112. LENORE WALKER, supra note 40 , at Xv. 
relationships with men. Furthermore, in order to be classified as a battered woman, the couple must go through the battering cycle at least twice. Any woman may find herself in an abusive relationship with a man once. If it occurs a second time, and she remains in the situation, she is defined as a battered woman. ${ }^{113}$

By 1984, in her second book, Walker had elaborated her description of battered women and developed another definition, now also cited by courts. This definition was not related to control but defined by incidents of violence: "A battered woman is a woman ... who is or has been in an intimate relationship with a man who repeatedly subjects or subjected her to forceful physical and/or psychological abuse. . . . 'Repeatedly' means more than one assault [at least two 'acute battering incidents']."114 Physical abuse is "any form of a coercive physical act, with or without resultant injury."115

Walker articulated her first, more control-focused definition of battered women based on an interest in women's lives growing out of her feminist consciousness. "16 However, the elaboration of "battered woman's syndrome" led away from an emphasis on power and toward a focus on incidents and behavior. Even Walker's first study showed some ambivalence about the implications of recognizing the issue of control. Walker found that as her women clients in psychotherapy became more assertive, they encountered more physical and psychological abuse. ${ }^{117}$

My first fear was that critics of the women's movement might be right. Perhaps violence erupted because women began to make their own decisions to control their lives. Feminism was indeed having a profound impact on the family by changing power relationships. Would strong, assertive women be able to live in harmony and equality with those men whom they loved? Fortunately, a further investigation proved these fears to be groundless; in those relationships where battering was occurring, coercion between the partners had existed from the beginning of the relationship. ${ }^{118}$

Walker flinched from the prospect that changes in power in relationships may generate violence or that men would resist changes in women's empowerment. This distinction between existent "coercion"

113. $I d$.

114. WALKER, SYNDROAs, supra note 110, at 203.

115. Id. at 202. Psychological abuse consists of eight elements, including periods of contrite, loving behavior that keep alive hope that the abuse will stop. Id.

116. See her account of the commencement of her work in LENORE WALKER, supra note 40 , at xi-xiii. Walker has also done extensive work to further feminist goals in psychotherapy through the Feminist Therapy Institute, of which she was a co-founder and the first chairperson. Conversation with Jeanne Adleman, Chair, Feminist Therapy Institute, 1988-1990 (1988).

117. LENORE WALKER, supra note 40 , at $x i$.

118. Id. at xi-xii. 
and "strong, assertive women" is somewhat stereotyping and fails to account for the existence of battered feminists. ${ }^{119}$ I believe that this psychological approach - not unique to Walker - also reflects white middle-class norms about the family: women are either strong and assertive or coerced. Some of us may be both - a lot may depend on the level and type of coercion involved. Especially, women who are not white or middle class may not fit these generalizations; ${ }^{120}$ they may have less difficulty reconciling the simultaneous experience of strength and oppression. ${ }^{121}$

However, Walker's definition is useful when women's experience must be described to a court. First, the definition is incident-focused: incidents can be asserted and often proven as objective support for the woman's perceptions and feelings. Second, the "repeatedly" requirement is a sorting mechanism that allows the judge or jury to consider the woman before them without accepting that any woman who has been struck even one time - a figure that may be familiar from their own relationships in ways they still deny - is susceptible to the development of battered woman syndrome. ${ }^{122}$

The various attempts by feminist scholars to define battering show some tension between breadth - reaching to include the many ways women are harmed - and precision in describing particular experience, which generally leads toward focus on incidents. Mary Ann Douglas gives a broad definition:

A battered woman is any woman who has been the victim of physical, sexual, and/or psychological abuse by her partner. ... Physical abuse is assault that ranges from hitting or slapping at one end of the continuum to homicide at the other [citing Pagelow]. Physical abuse may or may not be accompanied by physical injury and/or by the victims' attempts

119. Feminists and nontraditional women are also battered, and one author states it is questionable whether feminists have even a diminished tendency to be battered. OKuN, supra note 107 , at 86.

120. See Angela Harris, Race and Essentialism in Feminist Legal Theory, 42 StAN. L. REv. $581,612-13$ (1990) ("Feminist theory at present, especially feminist legal theory, tends to focus on women as passive victims. ... At the individual level, black women have had to learn to construct themselves in a society that denied them full selves.").

121. See Schneider, supra note 10 , at $216 \mathrm{n} .146$ (discussing the possibility that white women and their perspective have formed the basis for much of the literature on battering). I believe these descriptions poorly capture the discrepancy between how women appear to others and how they appear to themselves. In Walker's later study, The Battered Woman Syndrome, she found higher levels of self-esteem than she had in her previous study. WALKER, SYNDROME, supra note 110 , at 80-82, 114.

122. For further discussion of battered woman syndrome, see infra text accompanying notes 148-89. The "repeatedly" requirement also raises the issue of inquiry into the woman's "failure" to leave that expert testimony is designed to address; there may be less expectation that a woman would leave a marriage over only one incident of violence, which then in hindsight becomes the first such incident. 
to defend themselves. ${ }^{123}$

Douglas' definition has the advantage of being broad and inclusive, and explicitly rejecting any requirement that the woman have suffered physical injury. However, people may see one incident of violence as insufficient to distinguish "battering" from any ordinary relationship. ${ }^{124}$ Also, women do not always recognize being physically restrained from moving as a form of physical abuse when it is not mentioned specifically, and therefore this definition lacks some of the inclusiveness of Walker's "any physically coercive act."

Angela Browne's definition of battered women is more specific in its attention to incidents of assault:

"[B]attered women" are those who have been struck repeatedly, often experiencing several different kinds of physically violent actions in one incident, and usually, by the time they are identified, having experienced a series of such incidents, each consisting of a cluster of violent acts. ${ }^{125}$ If closely examined, Browne's definition reveals some of the other problems. It plays into women's denial by its specificity and its focus on "striking." Women who have been threatened with deadly weapons may fail to recognize their experience in this definition if they were not physically injured, as may women who have experienced other types of assault such as sexual abuse.

Mildred Pagelow defines battered women without requiring striking in a way that allows her to reconsider the question of repetition of violence:

[B]attered women refers to adult women who were intentionally physically abused in ways that caused pain or injury, or who were forced into involuntary action or restrained by force from voluntary action by adult men with whom they have or had established relationships, usually involving sexual intimacy, whether or not within a legally married state. ${ }^{126}$ Pagelow separates battering into "primary battering" (the first attack)

123. Mary Ann Douglas, The Battered Woman Syndrome, in Domestic VIolence on TRIAL, supra note 58 , at 39 .

124. See supra text accompanying note 113 (Lenore Walker stating: "Any woman may find herself in an abusive relationship with a man once.").

125. BROWNE, supra note 3, at 13. Since Browne's material was gathered in the Walker study, id. at ix, $196 \mathrm{nn} .1-2$, the works had identical underlying criteria despite the difference in language of their definitions. The emphasis on physical striking and patterns of repetition in Browne's definition is similar to that offered by Deschner: "a series of physically injurious attacks on an intimate or family member that form part of a repeated, habitual pattern." JEANNE P. Deschner, The Hitting Habit: ANger Control for Battering Couples 2 (1984), quoted in STORDEUR \& STILLE, supra note 81, at 19. Obviously Deschner goes further than Browne in requiring physical injury.

126. Pagelow, supra note 102, at 33. This definition may screen out women who have experienced such attacks as the pointing of a loaded gun or a knife held against the skin; some women who spoke with me identified such experiences as "emotional" rather than physical abuse. Diana Russell mentions a similar phenomenon in which many women fail to recognize marital rape as rape. RUSSELL, supra note 43 , at 63. 
and "secondary battering" (everything that follows). ${ }^{127}$ She views the woman's "acceptance" of the primary battering incident as the key to whether secondary battering will develop, because the woman's reaction to the first episode may in some way provide incentives for the man to continue, and thus move the relationship toward secondary battering. ${ }^{128}$ In this view, women reinforce battering through compliance with batterers' demands, giving them 'feelings of increased control and power."129 While this description identifies power and control as issues, it obscures them again by indirectly holding the woman responsible for the batterer's continued control efforts; ${ }^{130}$ it remains incident-focused with the second incident decisive for categorization.

Most of these definitions are essentially incident-focused, not control-focused. Falling into this conceptualization in describing their experiences, some women describe clear cut control struggles as separate from "battering":

The way it came out for me was not a battered woman's thing. I wanted to go out with my girlfriends, and that triggered possessive jealousy .... . He wouldn't let me go do the things I wanted to do, therefore the marriage wouldn't work. The problem didn't start with his beating me up. After I made my stand on that ground, then the violence started. That led to a lot of self-blame - if only I had been a better wife, this wouldn't have happened.

This woman has completed therapy, participated in a battered woman's group, obtained a bachelor's degree in sociology and a law degree. She is doing pro bono work with battered women. I would argue that the information she has been given, and her interpretation of it above, show a functional definition of battering as based on male violence that is not about control, and a "battered woman's thing" that is about the woman's "thing," rather than the batterer's pursuit of power.

Lesbian battering, in contrast, considers the victim of domestic vi-

127. Pagelow, supra note 102 , at $42-51$.

128. "The responsibility for taking decisive action at the first occurrence of battering appears to fall almost entirely on the woman. If . . . this behavior appears to be accepted by his spouse because of lack of negative feedback, he is most likely to continue it." Id. at 44.

129. Id. at 45. Pagelow does not explain what actions by women other than leaving at the first incident would be sufficient to avoid secondary battering, although she recognizes that in some relationships violence occurs only once.

130. Similarly, Pagelow says she rejects a focus on what "types" of women are battered as opposed to another type who are not. Id. at 223. Yet she formulates the "most important question" as "what are the characteristics (social and personal) that distinguish among women who are never battered, never battered a second time, or battered repeatedly?" Id. at 42 . This is merely another formulation of essentially the same focus. 
olence within the framework of continued attempts by the batterer to achieve and maintain dominance and control in the relationship:

Lesbian battering is that pattern of violent and coercive behaviors whereby a lesbian seeks to control the thoughts, beliefs or conduct of her intimate partner or to punish the intimate for resisting the perpetrator's control over her.

Individual acts of violence, by this definition, do not constitute lesbian battering. Physical violence is not battering unless it results in the enhanced control of the batterer over the recipient. If the assaulted partner becomes fearful of the violator, if she modifies her behavior in response to the assault or to avoid future abuse, or if the victim intentionally maintains a particular consciousness or behavioral repertoire to avoid violence, despite her preference not to do so, she is battered. ${ }^{131}$

Several elements of this definition merit discussion. Battering is a "pattern of violent and coercive behaviors" defined by the batterer's purpose. The state of being battered is defined by the woman's response. This would seem to exclude situations in which someone struck out in anger but did not hit hard, or in which they hit again but there was no effective intimidation; it would seem to include the times the furniture was smashed up and threats uttered, and the nonviolent partner was afraid to move or respond.

At first, the emphasis on the battered woman's response seems superficially similar to Pagelow's definitions of primary and secondary battering. However, the difference is crucial: the lesbian battering definition emphasizes a woman's experience of the violence, which may include either her feelings or her behavior; Pagelow targets her responsive behavior to emphasize her success or failure at nonrewarding the batterer. ${ }^{132}$ In essence, this defines the woman by her success at controlling the partner who is attempting to control her. This focus on the woman's experience does not automatically resolve problems of denial: women may not recognize how much our thoughts, feelings or actions are determined by the violence until a period of time has passed, or until the relationship is over. However, this approach does help the battered woman overcome denial: she need only recognize that she has modified her behavior or "intentionally maintain[ed] a particular consciousness or behavioral repertoire to avoid violence." These elements imply little stigma and help reveal the context of power and control within which the violence took place.

131. Barbara Hart, Lesbian Battering: An Examination, in NAMING THE VIOLENCE, supra note 33 , at 173.

132. I believe that this definition is useful and possible in part because lesbian battering is so seldom litigated. As a result, few if any of the power and control moves between lesbians wind up in the courtroom. 
Feminist activists writing about heterosexual battering have also defined power and control, rather than incidents of violence, as the heart of the question. Ellen Pence and Michael Paymar's training manual, which grew out of a treatment program for batterers in Minnesota developed by activists, is entitled Power and Control: Tactics of Men Who Batter. ${ }^{133}$ Pence and Paymar treat violence as a form of control ${ }^{134}$ and explicitly reject theories that focus on "some flaw in the abuser, the victim, the relationship, or all three of these."135

Incident-focused definitions have advantages in court which they lack if we look to them as a way to explain women's experience to ourselves and each other, support women, and fight oppression. For example, Pagelow's emphasis on traditional ideology in women may be very appealing to traditionalism in some jurors or in judges, who are mostly male: this woman was hurt and became so desperate because she was so determined to be a good wife and mother. Controlbased definitions may be more comprehensible to many women in regard to our own lives. However, women who resist types of control that have general societal acceptance (for example, women who resist traditional roles in their lives) may evoke less sympathy in judges or jurors who hold traditional values. If women are hurt for resisting domination, it may also be more difficult to explain the nature of the struggle in court simply because so many aspects of domination may appear normal and are subsumed under the label "traditionalism."136 In order to resolve the tensions inherent in the effort to define battering and battered women, we need to understand the pressures of the legal system and create solutions that change cultural consciousness as well as law.

\section{Pressures of the Legal System}

A. Self-Defense, the Battered Woman Syndrome, and Learned Helplessness

On the Defensive

Four a.m.

Watching his headlights

pan across the walls.

Listening to the familiar

engine's drone.

133. Ellen Pence \& Michael Paymar, Power and Control: Tactics of Men Who BATTER (1986).

134. See, e.g., id. at 64-83.

135. Id. at 64.

136. See infra text accompanying notes 250-57. 
The car door slam.

His keys.

His footfall on the stair.

I have this baby bottle.

Loaded, cocked, aimed and ready

to dash his skull to bits. ${ }^{137}$

Ironically, the most complete description of women's suffering from domestic violence has entered our case law and legal literature at the point where violence against women finally harms men - when battered women kill in self-defense. ${ }^{138}$ These are also the cases that have had the greatest impact on public consciousness of battered women. Francine Hughes, whose story became the book and movie The Burning Bed, killed her sleeping husband after years of extremely violent abuse. Although Hughes was acquitted on grounds of temporary insanity rather than on grounds of self-defense, her story became the paradigm for the image of battered women who kill their abusers. ${ }^{139}$

Although only a fraction of battered women kill their abusers, ${ }^{140}$ feminists and legal scholars put a great deal of energy into the selfdefense cases, which comprise a large portion of the legal literature on battering. ${ }^{141}$ Of course, the stakes are terribly high for the women involved in these cases: many women who are jailed for the murders of their abusers have been brutally and repeatedly abused. ${ }^{142}$

137. Linda Bart, On the Defensive, in Family Violence: Poems on the Pathology, supra note 1 , at 15.

138. See Cynthia L. Coffee, Note, $A$ Trend Emerges: A State Survey on the Admissibility of Expert Testimony Conceming the Battered Woman Syndrome, 25 J. FaM. L. 373 (1986-1987).

139. See, eg., Thyfault et al, supra note 58, at 68 (suggesting that attitudes of potential jurors toward battered woman syndrome may be elicited by asking whether they saw The Burning Bed).

140. An estimated 1.5 to 4 million women are battered in the United States each year. See supra note 42 . In 1984, approximately 477 husbands or boyfriends were killed by women. Laurie J. Taylor, Comment, Provoked Reason in Men and Women: Heat-of-Passion Manslaughter and Imperfect Self-Defense, 33 UCLA L. REV. 1679, 1680-81 \& n.10 (1986).

141. See Schneider, supra note 10, at $196 \mathrm{n} .5$ (citing 38 articles and Notes in law reviews and legal journals). Five more articles on the subject appeared in the issue of the Women's Rights Law Reporter. A review of the categories covering battered women and self-defense in "Infotrac" reveals that in the ensuing three years, at least a dozen additional pieces appeared, totaling at least 50 to 60 published pieces on the subject. In 1987, two more books on the subject were published: Browne, supra note 3, and CHARLes P. EWING, BATTERED WOMEN Who KILI (1987). In 1989, three more new books appeared. See BLACKMAN, supra note 11; GILLESPIE, supra note 11; WALKER, supra note 11.

142. Angela Browne's study brought together statistical findings based on a large sample of women and explored in depth the stories of eleven couples. The women in these couples had been severely, even grotesquely, abused over a period of years. Seven of them served sentences from one year to life in prison. Two received suspended sentences or probation. In one case, the district attorney's office finally agreed that the slaying was justifiable and dropped charges. One woman was tried for first-degree murder, pled self-defense, and was acquitted. BROWNE, supra note 3 , at $187-90$.

Last year, the governor of Ohio released 25 women who had been serving prison terms after 
When a woman is tried for killing her abuser, she encounters not only the problem of the jury's ability to understand her experience, ${ }^{143}$ but the problem of articulating her experience in court in the first place. Lenore Walker argues that the rules of evidence prevent the explanation of women's experience:

There is a fundamental difference between the way women tell of their battering experiences and what is permitted under the male-identified rules of evidence. Women tend to tell of the events in question rooted in their context, by weaving a tale of patterns of events and feelings in the context of how they happened. Rules of evidence call for the recitation of discrete events separated from feelings or opinions. Facts out of context may be acceptable, but they do not convey the battered woman's experience. Expert witnesses can tie together what the current evidentiary rules do not allow the defendant to say. Until feminist legal scholars argue for and attain reform in the rules of evidence, a battered woman will be constrained from putting her case in front of the trier of fact. ${ }^{144}$

The conditions of women's lives - the children needing sweaters or needing noses wiped, ${ }^{145}$ or the constant demands of breastfeeding or diapers ${ }^{146}$ - may not be seen as relevant to the explanation of the violent marriage or even to the question of why women "stayed." Similarly, a statement that a husband's drinking problem developed after many happy years is not adequate to capture the keen, passionate consciousness of love and responsibility for both husband and children articulated by the woman who was in my support group. ${ }^{147}$ Finally, a woman's perception of danger and her decisions to act are dependent on the context of that particular relationship. Therefore, these "maleidentified" rules constrain the categories within which the legal image of battered women has evolved.

Expert testimony on battered woman syndrome was developed by feminist litigators and psychologists to explain the experiences of abused women and the way women were affected by abuse. ${ }^{148}$ Battered woman syndrome is "a collection of specific characteristics and

reviewing their records carefully. The women presented evidence of abuse. More than one hundred women's records were reviewed. Isabel Wilkerson, Clemency Granted to 25 Women Convicted for Assault or Murder, N.Y. TIMES, Dec. 22, 1990, at 1, col. 1.

143. See supra text accompanying notes 58-60; see also Littleton, supra note 34, at 35 ("Not only battered women but all women" are alien from a male perspective, and therefore beyond the ken of laymen.).

144. Walker, supra note 10 , at 223-24.

145. See supra discussion of children's needs in poem in text accompanying note 83.

146. See supra narrative in text following note 83.

147. See supra narrative in text following note 82 .

148. Schneider, supra note 10 , at 198. 
effects of abuse on the battered woman."149 While it does not affect all battered women, it makes women who do suffer from the syndrome unable to respond effectively to violence and therefore entrapped in the violent relationship. ${ }^{150}$ Testimony on battered woman syndrome includes a description of Walker's three-stage battering cycle, ${ }^{151}$ the concept of "learned helplessness," and may also include descriptions of the objective economic and social difficulties women face in leaving their relationships. ${ }^{152}$

In most states, ${ }^{153}$ testimony on battered woman syndrome is admitted under the rule of evidence that allows expert testimony when the jurors could not understand the issue without it. 154 "[A] battering relationship is a subject beyond the understanding of an average juror."15s Jurors are particularly unable to grasp for themselves why the woman failed to leave the relationship. ${ }^{156}$ Judges may have grasped the need for expert testimony through motives of justice, empathy, recognition of the need to cope with prejudices and stereotypes held by jurors, or similar reasons. Yet judges and jurors will inevitably hear this testimony filtered through cultural stereotypes which are of necessity enforced by the claim of exceptionality, of incomprehensibility, required by the requirement that the issue be "beyond the layman's ken." The result may often tend to perpetuate stereotypes:

[T] he expert testified that those who suffer from the battered woman syndrome, because of certain characteristics in their personalities, do not leave their husbands, even after numerous beatings, do not inform police or friends of their husbands' violence, and, under certain circumstances, believe that they are in present danger that their husbands will kill them, although some time has elapsed since the husband's last assault against them. ${ }^{157}$

149. Douglas, supra note 123 , at 40.

150. Id.

151. Walker divides battery into three stages: the tension building phase, the explosion or acute battering incident, and the calm, loving respite. LENORE WALKER, supra note 40, at 55. The periods of loving remorse are essential in cementing bonding between the couple and renewing hope for change.

152. Schneider, supra note 10 , at 202-03.

153. For a discussion of state and federal rules, see $i d$.

154. See, eg., Smith v. State, 277 S.E.2d 678, 683 (Ga. 1981) ("Expert . . . testimony . . . is admissible where the conclusion of the expert is one which jurors would not ordinarily be able to draw for themselves; i.e., the conclusion is beyond the ken of the average layman").

155. See, e.g., Kansas v. Hodges, 716 P.2d 563, 567 (Kan. 1986).

156. See, e.g., People v. Torres, 488 N.Y.S.2d 358, 362 (Sup. Ct. 1985) ("[T] he proffered expert [testimony] would ... serve to dispel the ordinary lay perception that [the] woman who remains in a battering relationship is free to leave her abuser at any time .... [T] he jury's 'commonsense' conclusions [would be] that the beatings and threats ... could not have been at all that bad or else she would have left long before.").

157. Chapman v. State, 367 S.E.2d 541, 543 (Ga. 1988) (emphasis added) (reversing for ex- 
Feminist litigators grapple with the difficulties presented by portraying women in a complex life situation, both acting and being acted upon - what Elizabeth Schneider has called a contrast between agency (the woman as actor and agent in her own life) and victimization (the woman as acted upon by her batterer). ${ }^{158}$ As Schneider points out, however, even if litigators tell a more complex story, the legal and cultural pressures at work in this area contribute to the judges hearing and retelling a story of dysfunctionality. ${ }^{159}$ Courts describe a battered woman who is "financially dependent on the batterer," which may cause her to "feel partly responsible for the batterer's violence, [also,] she may believe that her children need a father, or fear reprisal if she leaves." ${ }^{160}$ She is powerless, lacks selfesteem, and has few close friends. ${ }^{161} \mathrm{Her}$ "self-respect is very low and she believes she is a worthless person." 162 Her primary emotion is fear. ${ }^{163}$ She undergoes a personality change and is "unable to project her thinking into the future. She lives her life from one beating to the next and her thoughts relate solely to her efforts to avoid the next beating." 164

Significantly, this description explains her continued presence in the relationship, her failure to separate: her emotional paralysis and inability to think clearly are the reasons she cannot think clearly about escape. 165 She has "traditional beliefs about the sanctity of home and family and ... false hopes that things will improve."166 Among the most important aspects of her problem is the condition of "learned helplessness," described with varying degrees of sophistication as a de-

clusion of testimony regarding victim's reputation for violence). In another Georgia case the discussion of Smith also reinforced this perception of battered women:

We reasoned that a jury could not ordinarily draw certain conclusions for themselves, such as; "why a person suffering from battered woman's syndrome would not leave her mate, would not inform police or friends, and would fear increased aggression against herself..." [citing Smith v. State, 277 S.E.2d 678, 683 (Ga. 1981)] Testimony regarding the battered woman syndrome assists the jury in understanding the defendant's unusual behavior and conduct, which are vital issues in the battered woman's defense. . . . [which is] beyond the ken of the jury ....

State v. Butler, 349 S.E.2d 684, 687-88 (Ga. 1986).

158. Schneider, supra note 10 , at 220-22. Victimization can also include trying to describe the woman's life in the context of a male-dominated system.

159. Id. at 198-99.

160. Fennell v. Goolsby, 630 F. Supp. 451, 456 (E.D. Pa. 1985).

161. Ibn-Tamas v. United States, 407 A.2d 626, 634 (D.C. 1983).

162. Smith v. State, 277 S.E.2d 678, 680 (Ga. 1981).

163. Smith, 277 S.E.2d at 680.

164. People v. Emick, 103 A.D.2d 643, 654 (N.Y. App. Div. 1984).

165. People v. Torres, 488 N.Y.S.2d 358, 361 (Sup. Ct. 1985) ("Numbed by a dread of imminent aggression, these women are unable to think clearly about the means of escape from this abusive family existence.").

166. Torres, 488 N.Y.S.2d at 361. 
ficiency in perceiving escape possibilities ${ }^{167}$ or a psychological adjustment to economic dependence, love, and the failure of the legal system to respond adequately to the problem. ${ }^{168}$

These opinions present an image of utterly dysfunctional women. 'Such testimony generally explains the 'phenomenon' as one in which a regular pattern of spouse abuse creates in the battered spouse low self-esteem and a 'learned helplessness,' i.e., a sense that she cannot escape from the abusive relationship she has become a part of."169

A conversation between two friends who had violent marriages:

R: They say we have this thing called "learned helplessness" ... .

Y: Really? I always thought it was when I was getting too much power.

Martin Seligman developed the psychological theory of "learned helplessness" based on laboratory experiments conducted on animals. ${ }^{170}$ Caged dogs subjected to repeated random electrical shocks that they could not control eventually "ceased any further voluntary activity and became compliant, passive and submissive."171 Even when it was possible for dogs to leave the cages, they "remained passive, refused to leave, and did not avoid the shock."172 In 1979, Lenore Walker applied the theory of learned helplessness to the battered women she studied:

Once the women are operating from a belief of helplessness, the perception becomes reality and they become passive, submissive, "helpless." They allow things that appear to them to be out of their control actually to get out of their control. When one listens to descriptions of battering incidents from battered women, it often seems as if these women were not actually as helpless as they perceived themselves to be. However, their behavior was determined by their negative cognitive set, or their perceptions of what they could or could not do, not by what actually existed. The battered women's behavior appears similar to that of Selig-

167. "[A] feeling of surrender and a failure to realize or know options available to escape the relationship." State v. Kelly, 685 P.2d 564, 567 (Wash. 1984).

168. "[A] condition in which the woman is psychologically locked into her situation due to economic dependence on the man, an abiding attachment to him, and the failure of the legal system to adequately respond to the problem." State v. Allery, 682 P.2d 312, 315 (Wash. 1984).

169. State v. Leidholm, 334 N.W.2d 811, 819 (N.D. 1983) (footnote omitted).

170. See, e.g., discussion in GONDOLF \& FISHER, supra note 12, at 13 ("The prevailing notion of learned helplessness is drawn from the extensive laboratory research of Martin Seligman of the University of Pennsylvania . . . . During the late sixties, Dr. Seligman led a team of researchers experimenting with dogs in studies that would raise the ire of today's animal rights activists.") (citation omitted).

171. Walker describes Seligman's experiments in LENORE WALKER, supra note 40, at 45-47. The hidden question of captivity in Seligman's experiments and Walker's interpretation is discussed further, infra notes 364-66 and accompanying text.

172. LENORE WALKER, supra note 40 , at 46. 
man's dogs, rats, and people. ${ }^{173}$

Although Walker later cautioned against overgeneralizing about women's responses to violence, learned helplessness and its attendant images of submissiveness and passivity underlie much of the expertise on battered woman syndrome and much of the legal literature. ${ }^{174}$ Even in Walker's 1984 study, which in some ways revealed a more complex portrait of battered women, ${ }^{175}$ the discussion of battered women's "coping skills" revealed the ongoing importance of the concept of learned helplessness:

[B]attered women develop survival or coping skills that keep them alive with minimal injuries. There is also some evidence that such skills are developed at the expense of escape skills. [It is] consistent with [learned helplessness] theory to narrow one's perceptions and focus only on survival, causing misperception of other important information. . . . I interpret their behavior as a basic coping mechanism, much like Seligman's dogs, who used passivity as their way to stay alive. The analogy is in the failure for both the dogs and the battered woman to develop adequate escape skills. ${ }^{176}$

Feminists have cautiously criticized the way learned helplessness emerges in court both for failing to fully explain the many aspects of battered women's behavior ${ }^{177}$ and for creating a double bind in which women must prove helplessness in court after they have killed an abusive partner and therefore do not appear helpless as the term is ordinarily understood:178 "[A] defendant may be considered a battered woman only if she never left her husband, never sought assistance, and

173. Id. at 48.

174. For example, the following passage from the Joumal of Family Law makes passivity and submissiveness an integral part of the syndrome:

The battered woman syndrome is a term used to describe the stages of a physically and psychologically abusive relationship with a mate and the effects of each stage of the relationship on the battered woman. Three stages of a battering relationship have been identified by Dr. Lenore E. Walker in her book entitled The Battered Woman. ... Due to the repetition of this pattern, the woman develops certain learned responses. The batterer's false promises of reform in the third stage result in repeated disappointments and cause the woman to develop a learned helplessness evidenced by extreme passivity and submissiveness.

Coffee, supra note 138, at 373 n.1 (emphasis added).

175. In her later work, Walker found battered women often held liberal rather than traditional attitudes and had higher self-esteem than she expected to find. WALKER, SYNDROME, supra note 110 , at 143 .

176. Id. at 33.

177. See generally Littleton, supra note 34; Schneider, supra note 10.

178. For example, in Mullis v. State, 282 S.E.2d 334 (Ga. 1981), testimony on battered women was excluded. Although the court offered no specific grounds for excluding the testimony on battered women, the evidence had clearly demonstrated the defendant's ability to fight back and may have made her seem less "helpless." Mullis, 282 S.E.2d at 336-37. Georgia courts had earlier accepted testimony on the battered woman's syndrome in a case where the defendant had never resisted. See Crocker, supra note 18, at 146 (interpreting Mullis as showing an implicit requirement that the woman never fight back). 
never fought back."179 To the extent the theory of learned helplessness is based on repeated violence, women may have trouble establishing the appropriateness of expert testimony if they strike back after experiencing one severe prior incident of abuse. ${ }^{180}$

It is difficult to communicate the cumulative effect of a violent marriage. A great deal of the literature on battering develops themes and conclusions through presentation of women's stories. While in part this reflects a feminist methodology of working from women's experience, ${ }^{181}$ it also may be the only way to describe a complex reality for which we have few names. ${ }^{182}$

If the woman does need expert testimony, how can her reality be described? Elizabeth Schneider has expressed concern over the tendency of testimony on learned helplessness to promote stereotypes of women and undermine examination of the woman's particular circumstances, ${ }^{183}$ as well as the way carefully framed feminist testimony on learned helplessness may be distorted in the courtroom. ${ }^{184}$ Some authors find the term "learned helplessness" misleading because "helplessness" is only one coping tactic among many that change over time. ${ }^{185}$ Most important, women's stories as well as much social science literature indicate that many battered women seek energetically to protect themselves and their families. In this vein, the most socially situated description of learned helplessness describes it as a product of the interaction of frustrations women meet as they energetically pursue safety. ${ }^{186}$

179. Crocker, supra note 18 , at 144. Crocker points to a confict with the "reasonable man" standard in self-defense cases: "If the defendant has tried to resist in the past, the court accepts this as evidence that rebuts her status as a battered woman. On the other hand, if the defendant has never attempted to fight back, the prosecution argues that the defendant did not act as a 'reasonable man." " Id. at 145; see also id. at 152-53 (discussing the tensions between sex-neutral standards, male definitions of "objectivity," and individualization theories).

180. See id. at 147 (discussing State v. Griffiths, 610 P.2d 522 (Idaho 1980)). "[T]he defendant shot her husband after seeing a look in his eyes which she had seen only once before when he choked her to near insensibility." Id.

181. See generally Littleton, supra note 27 (discussing feminist methodology of working from women's experience); see also West, supra note 63 (discussing need for phenomenological critique based on women's stories of their own experiences, and employing this method).

182. See generally Kelly, supra note 31, at 114-17 (on importance of naming women's experience).

183. Elizabeth M. Schneider, Equal Rights to Trial for Women: Sex Bias in the Law of SelfDefense, 15 HaRV. C.R.-C.L. L. REv. 623, 646 (1980).

184. Schneider, supra note 10, at 198 ("Even if lawyers are not emphasizing [the woman's learned helplessness rather than the circumstances,] judges are hearing it this way.").

185. See Kelly, supra note 31 , at 114; see generally GoNDOLF \& FiSHER, supra note 12 , at 27-39 (describing many types of helpseeking behavior by battered women).

186.The battered woman who meets with failure in [all her] tactics to create her own safety experiences a series of lessons in the reality that neither her behavior, nor that of any other woman[ ], is able to stop the violence against her ... she cannot control the actions of her 
I do not mean to criticize here the psychological theory underlying battered woman syndrome, or even the particular theory of learned helplessness. First, the collection of experience and perception summed up in battered woman syndrome are descriptively true of many women. ${ }^{187}$ Lenore Walker's defense of expert testimony is also correct: it helps women's stories be brought into court by bringing together fragments that women experience as part of a whole relationship. ${ }^{188}$ Finally, I would not choose to discard such a major tool in the effort to explain women's experience in court, just because it has proved vulnerable to distortion in culture and law - we need more, not less, explanation. However, as long as explanation emphasizes "helplessness" in the psychology of individual women, it runs into the danger of contributing to stereotyping.

Therefore, a profound irony marks this expert testimony: Domestic violence is beyond the layman's ken (even though we know it is fairly common) because some jurors will interpret their own experience through cultural perceptions that distort understanding and make it difficult for all of us to talk about the subject, and because cultural stereotypes will shape the vision of battered women held by jurors who have no personal experience of such violence as well. Expert testimony, designed to overcome these stereotypes and help show the context for the woman's actions, has through the pressures of the legal system contributed to a focus on victimization that is understood as passivity or even pathology on the part of the woman. ${ }^{189}$ This image further promotes many cultural stereotypes, and may contribute to further stigmatizing of battered women and further denial by women of the dangers they face through domestic violence. In a particular legal action, an individual battered woman's experience is at least partly explained, but the cultural perceptions that limit broader social understanding may remain untouched, and go on to shape legal action again.

partner. Learned helplessness in battered women refers to the low rate of behaviors that could potentially increase safety, based on her decreased ability or on her judgment that these behaviors are also unsafe. [Since her judgment of the dangers of helpseeking may be realistic,] the presence of certain behaviors associated with learned helplessness is not necessarily irrational or unreasonable. ... They may be what kept her alive.

Douglas, supra note 123 , at $42-43$.

187. See also the support for battered woman syndrome theory discussed in the amicus briefs of the American Psychological Association and American Civil Liberties Union in State v. Kelly, reprinted in 9 WOMEN's RTS. L. RPTR. 245 (1986).

188. See supra notes 143-47 and accompanying text.

189. Schneider, supra note 10, at 207 ("[T] he term 'battered woman syndrome' has been heard to communicate an implicit but powerful view that battered women are all the same, that they are suffering from a psychological disability and that this disability prevents them from acting 'normally." "). 
Therefore, one result of the highly publicized legal focus on battered woman syndrome and learned helplessness has been to inappropriately increase cultural attention to the battered woman's psychological makeup. Evidence suggests that the batterer's behavior, rather than the battered woman's characteristics, determines her response and predicts whether she will kill in self-defense. ${ }^{190}$ Yet placing courtroom emphasis on the batterer's conduct has its own pitfalls: for example, cases in which violence took nonstandard forms may prove confusing, and much domestic violence might not be comprehensible to the jury without a simultaneous exposition of the context and history of the relationship. ${ }^{191}$ Also, the explanation of the woman's experience and interpretation of violence may again be lost by too much focus on the batterer.

In the past, we have lacked explanatory language and litigative strategies for exposing the batterer's quest for power and control the link between the conduct of the batterer and the experience of the woman. Evidentiary rules and courtroom bias therefore continue to skew the image of women in the self-defense cases, and these cases continue to contribute to cultural images that in turn shape law. Below, I propose a collateral attack on this problem. By identifying those violent power and control moves that target the woman's separation, we can begin to bridge the gap between self-defense and other battering cases. Because of the interrelatedness of the legal rules and cultural attitudes in this area, we need law reform that illuminates the nature of power and control in all areas of battering.

\section{B. Custody and the Professional Evaluation of Women}

A custody battle is the quintessential power struggle between men and women. It's about who controls a woman's mind and body. It's also about who gets to control the future. Children are the future. Men think of children as the necessary chains to keep wives from flying away. If we fly away anyway, they transfer their needs to their children. ${ }^{192}$

Women fear losing our children upon divorce. ${ }^{193}$ During mar-

190. BROWNE, supra note 3, at 127. Browne found seven predictors of homicide in a battering relationship. Only one of these (the woman's threats of suicide) is based on the woman's behavior; all the other predictors (frequency of abusive incidents, extent of woman's injuries, frequency of forced sexual acts by man, man's drug use, and frequency of his intoxication) are based on actions by the man. Id.

191. This problem is symmetrical to the dangers that helplessness theories pose for women who fight back against violence.

192. Anonymous quotations from mothers on custody battles, from the chapter, Mothers' Voices, Written on the Wind, in CHESLER, supra note 14, at 449.

193. WeITZMAN, supra note 82 , at 311 (stating that men see custody as part of a total package of divorce issues; women "are more likely to consider custody on an altogether different level 
riage, women are usually primary caregivers for children, even when both father and mother work full time. ${ }^{194}$ In Lenore Weitzman's study of divorce, one third of the women interviewed reported their husbands threatened to seek custody as a ploy in postseparation negotiations, usually because they sought financial gains. ${ }^{195}$ Women routinely sacrificed support to which they would otherwise be entitled in order to avoid even the risk of losing their children. ${ }^{196}$ Other studies have observed a dynamic with regard to domestic violence that parallels the financial bargaining Weitzman recounted: rather than face custody suits, women accept mutual orders of protection, which are inappropriate if the woman has not been violent and can hinder the effectiveness of the protective order. ${ }^{197}$ In both instances, women lose protection they need and to which they are legally entitled, because they fear the treatment they are likely to receive in court. ${ }^{198}$

These fears are realistic. ${ }^{199}$ First, since so many divorcing women report they have experienced violence, the problem is common. Second, violent men will likely seek new means of control when old ones fail. Batterers use the legal system as a new arena of combat when they seek to keep their wives from leaving. 200 Of the women whose stories are in this paper, all but one who had children at the time of divorce have either fought a custody action or were threatened with one. ${ }^{201}$

Men who pursue custody have a better than even chance of gaining

- it is something they simply cannot negotiate about because it is too important — it is worth any price").

194. Fineman, supra note 82 , at 769 \& n.166; see also WEITZMAN, supra note 82 , at 240 (noting that husbands spend even less time with their children when their wives are employed).

195. WEITZMAN, supra note 82 , at 310 .

196. Id. at 311-12.

197. New York Task Force Report, supra note 51, at 40 n.84.

198. One woman obtained a temporary restraining order when her husband threatened to move back in without her consent or to take away the children if she refused to reconcile. See narrative regarding fear of opinion of therapist, text following infra note 217. After being served with the order, her husband offered to drop the threat of a custody suit if she would agree not to obtain a permanent protective order. She agreed and allowed the temporary order to expire without seeking a permanent order. She was pleased, in part because she believed that permanent orders would be difficult to enforce. In actuality, horvever, she had agreed to less legal protection solely in order to protect her relationship with her infant children.

199. For a discussion of the problem of domestic violence in custody decisions, including cases in which courts awarded custody to violent or even murderous fathers, see Naomi Cohen, Civil Images of Battered Women: The Impact of Domestic Visience on Child Custody Determinations, VAND. L. REV. (forthcoming).

200. Lenore E.A. Walker \& Glenace E. Edwall, Domestic Violence and Determination of Visitation and Custody in Divorce, in DOMESTIC VIOLENCE ON TRIAL, supra note 58, at 130.

201. The one woman who reported no such threat had a husband disabled by mental illness who was not working steadily at the time of divorce. 
custody. ${ }^{202}$ Even violent men are frequently successful in custody suits. In one study, fifty-nine percent of the judicially successful fathers had physically abused their wives; thirty-six percent had kidnapped their children. ${ }^{203} \mathrm{~A}$ recent article estimated that at least one half of all contested custody cases involved families with a history of some form of domestic violence; in approximately forty percent of those cases, fathers were awarded the children irrespective of their history of violence. ${ }^{204}$ Another study reported many awards of custody to battering fathers, including one case in which the judge made his decision after walking past the shelter to which the mother and children had fled. The judge found the shelter to be an inappropriate living arrangement and concluded the father provided the better home. ${ }^{205}$

The past two decades have seen major changes in child custody litigation. ${ }^{206}$ Martha Fineman has explained how the advent of gender-neutral rules in custody decisionmaking created a situation that actually disfavors women, since factors that would favor women, such as nurturing, are defined as gender-biased. ${ }^{207}$ In devaluing past caregiving and seeking decisionmaking factors that would not inherently prefer women, courts have wound up relying on factors such as financial resources that usually favor men. ${ }^{208}$

With the advent of no-fault divorce, fault became relevant only in custody proceedings. ${ }^{209}$ This contributes to a critical evaluation of mothering and holds particular problems for women leaving violent marriages. Violence against women is less likely to be raised at all in a no-fault action. It may be dangerous for women to raise the issue of domestic violence, since it invokes stereotypes that judges or social

202. Martha L. Fineman \& Anne Opie, The Uses of Social Science Data in Legal Policymaking: Custody Determinations at Divorce, 1987 WIS. L. REv. 107, 120 \& n.37. In one study, 70\% of 37 judges ordered children into paternal custody. CHESLER, supra note 14, at 80-81. In Weitzman's study, men who requested custody received it $63 \%$ of the time in negotiated cases. Weitzman found that in many cases where fathers received custody there was some explicit or implicit agreement by the mother. However, the "agreement" sometimes appeared to have been coerced by threats against the woman's safety, reputation, or financial security. WEITZMAN, supra note 82 , at $233-34$. Men won $33 \%$ to $38 \%$ of the cases that were fully contested in court. Id. at 234.

203. ChesLer, supra note 14 , at 81.

204. Walker \& Edwall, supra note 200 , at $127,130$.

205. New York Task Force Report, supra note 51, at 42.

206. See, e.g., Fineman, supra note 82, at 738-39; Fineman \& Opie, supra note 202, at 113-21. Beginning in the 1970s, feminists sought to construct a notion of woman not tied to the idea of mothering. Simultaneously, in a reaction to women's liberation, father's rights groups challenged the assumption of maternal custody that had characterized the preceding period. See id.

207. Fineman \& Opie, supra note 202, at 121.

208. Id.

209. WeITZMAN, supra note 82 , at 223. 
workers may hold. It may not even be helpful: in the absence of physical harm to a child, violence against the mother might not be seen as relevant to the welfare of the children. ${ }^{210}$ Women therefore must decide whether to describe the violence against them - and risk judicial stereotyping - or keep silent, and allow the violence of their spouse to be judicially invisible.

The difficulties here have been exacerbated by the simultaneous development of several liberal legal reforms. Feminist litigation on battered women's syndrome occurred contemporaneously both with the attempt - as part of some feminist visions of equality - to make motherhood less central to women's identity, and with the advent of no-fault divorce. The evolution of a dysfunctional portrait of battered women therefore occurred simultaneously with the changes wrought by no-fault and joint custody. Indeed, by making violence against women less visible at divorce, no-fault divorce laws may have indirectly contributed to cultural stereotypes of battered women by removing public blame of the perpetrator of the violence. Once the man as bad actor disappears, it is easy to shift the focus to the woman. Rather than asserting his harm to her from the beginning, the woman must raise battering as an issue defensively, while she is being clinically evaluated, with greater attendant risk of stereotyping.

The resulting legal dangers appear in many women's stories. Angela Browne tells of a woman who left her husband after the third "physically assaultive incident" had endangered their infant son. She went into hiding with relatives and consulted an attorney to file protective orders and obtain a divorce. The husband sought custody and claimed that his wife's disappearance from the family home proved her instability. Because the woman had left before the violence became grotesque, she was not treated as having been seriously endangered. The state placed the child with the abuser's family because they were considered stable; his family then fought to restrict the mother's visitation. The welfare department finally recommended the baby remain with its grandparents since they had been taking care of it, noting "the fact that their stories [were] so contradictory makes both parents seem unreliable."211 Christine Littleton tells a similar story: a

210. Walker \& Edwall, supra note 200 , at 140.

211. BROWNE, supra note 3, at 112-13.

This woman's story provides one answer to the question: "Why don't battered women leave?" The woman acted independently and rationally: She left the situation when she began to realize that it would not improve; she refused to tolerate victimization; she sought legal remedies. She escaped her abuser before the violence was serious. She may also have lost her child.

Id. at 113. 
woman who had obtained a restraining order against her husband awoke one night to find him wielding a knife in her bedroom; after she fled into the night, he claimed she had abandoned the children, and she was unable to regain custody. ${ }^{212}$

No-fault divorce and the widespread adoption of the "best interest of the child" standard for resolving custody disputes also put more power in the hands of professionals such as social workers. ${ }^{213}$ Judges follow the recommendations in evaluations ninety percent of the time. ${ }^{214}$ The increased reliance on these professionals created problems for battered women with children. Even before separation, it may be dangerous to place much trust in a counselor who may later be called on to testify regarding the qualities of the parents:

The problem is, I feel as if the therapist likes him better. She took it seriously the day he had attacked me. But then I decided I wanted a separation, and I asked him to leave. She told me that "the person who wants the separation should be the one who leaves." It's student housing - it's my apartment. But I'm afraid to argue with her. I don't know what she'll do if he tries to take the children.

This woman was right to perceive the marriage counselor as a hazard. ${ }^{215}$ Therapists can prove susceptible to the charm of batterers. ${ }^{216}$ The battered woman often believes she is a less attractive figure than her spouse. "Who would like me? Can't think straight, crying, depressed ... ugly . . . tired, twenty years old, with two kids to support. ..." Therapists may justify the batterer during the counseling process, or break the wife's confidence to inform the batterer of the wife's complaints of violence, as well as posing a danger in the event of later custody disputes. ${ }^{217}$

The woman's unwillingness to compromise may be penalized as well. A woman may manage to drag the man into marriage counseling, yet despair after continued problems and seek a separation. Both

212. Littleton, supra note 34 , at 54 .

213. Fineman, supra note 82 , at $740-44$.

214. Sun \& Thomas, supra note 14 , at 573.

215. Family systems theory has great influence in the field of social work today. Fineman, supra note 82 , at 744-45 \& nn.77-81. The family systems approach strongly protects the status quo. When a woman describes her husband's violence, social workers following family systems theory often ask the woman to focus on what she did to provoke the man. STORDEUR \& STILLE, supra note 81 , at 26.

216. Walker \& Edwall, supra note 200 , at 141 ; see also LOUISE ARMSTRONG, ThE HOME FRONT: NOTES FROM THE FAMILY WAR ZONE 37-62 (1983) (describing how psychiatrists misconstrue or even ignore the realities of abuse); LENORE WALKER, supra note 40, at 248-50 (discussing sexist attitudes among psychotherapists).

217. See, eg., Anonymous, Letter to the Editor, Why Battered Wives Don't Leave Home, N.Y. TMES, Dec. 29, 1983, at A18 (describing the counselor's violation of confidences in order to establish "trust and communication"). 
the charm of the batterer and the therapist's desire for an evenhanded, unifying solution may lead to problems.

My husband threatened to try to take the children from me, to tell the court I was unfit, that my friends were a bad influence. The therapist had always liked him better, and for several months I had been afraid she would be biased against me if she testified. But by the time he made the threat I wasn't as scared as I had been, because I knew I had won. He had finally lost the therapist as an ally - not by pulling a gun on me, not by being proud of it later and scaring her so badly that day - but by failing appointments when I continued to make them.

The battered woman fearing a custody action therefore faces powerful forces that may be hostile or difficult to control. Mothers generally fare poorly in the professional literature used by social workers. ${ }^{218}$ Battered women face additional difficulties from court reliance on social workers and other professionals in evaluating contested custody issues, since few evaluators have much training at understanding the impact of battering on the child as well as the woman. ${ }^{219}$ Also, the background of Freudian psychology, with its emphasis on women's masochism, still affects some of the psychological and sociological expertise in the field of domestic violence. ${ }^{220}$ Feminist scholars have particularly criticized family systems theory, widespread in the field of social work today, for its tendency to equalize responsibility for the violence: ${ }^{221}$ the family systems view of battering as an interaction between family members tends to blame the victim for failing to stop the violence, and to define success as reconciling the partners in the relationship rather than as stopping the abuse. ${ }^{222}$

Finally, battered women with children face an image problem. We need to be strong, resourceful, effective as a parent, meeting the needs of the children when we appear in court. On the other hand, if we do that too well, the court may disbelieve our stories because of stereotypes held by judges or psychologists. ${ }^{223}$ If the court will consider

218. Fineman, supra note 82 , at $767 \mathrm{n} .161$ (noting that in 125 articles studied, mothers were blamed for 72 psychological disorders in children; no mother-child relationships were described as healthy, though some father-child relationships were described as healthy).

219. Walker \& Edwall, supra note 200, at 140; Sun \& Thomas, supra note 14, at 573.

220. See ARMSTRONG, supra note 216, at 16-36.

221. Family systems theory tends to view the divorcing family as a whole rather than looking at individuals and to seek to accommodate the entire family's transition to a new set of relationships. Fineman, supra note 82, at 744-45 \& nn.77-81.

222. STORDEUR \& STILLE, supra note 81 , at 25-26.

223. Crites \& Coker, supra note 14 , at 13 . One such story was recounted by a social worker, whose client had been evaluated by a therapist as too strong to have been a battered woman and too upset about her ex-husband, considering that two years had passed, to be a stable parent. The ex-husband had continued his attacks for two years, including such calculated violence as cutting the brake lines on her car. Conversation with Donna Coker, supra note 67. 
violence as a factor at all in custody decisions, we may be seen as - or in effect be required to appear as - having been weak, helpless, and economically dependent to have "stayed" with the man all these years.

The hazards are obvious. In self-defense claims, we have pressed upon judges and juries a portrait of induced dysfunctionality. In custody cases, we must prove functionality - or at least recovery. ${ }^{224}$ The concept of "learned helplessness" is a factor that may influence negative custody decisions. ${ }^{225}$ The needs of battered women in custody cases seem almost directly inverse to self-defense cases: women must prove our subjective reasonableness for self-defense claims, our objective rationality and competence as parents; learned helplessness may "explain" why a woman "stayed" in the self-defense context, but may be interpreted as making her a poor model in childrearing and possibly a poor caregiver as well when custody is in question. The cases may not always be tried before the same judges, but they work within the same legal system and popular culture. To the extent that our psychological literature has been focused on "battered women" rather than the violent power and control moves against these women, it perpetuates stereotypes that damage us in our other encounters with the legal system.

Therefore, fear of the law controls some of the behavior of battered women with children. A woman who leaves her husband may wind up on the defensive regarding custody, subject to rules that disfavor her which are then interpreted through negative cultural images. Through this interaction of the power of the legal system and the man's violent moves for control, women are hindered in simultaneously protecting ourselves and our relationships with our children. In this impossible bind, we may end temporary separations under pressure from social workers ${ }^{226}$ or from fear of custody actions, ${ }^{227}$ or make concessions over needed financial support or the level of protection we demand or receive from the state. We may also reluctantly accept dangers we can observe and respond to personally - the threat of violent men we know - to avoid the uncertainties of custody suits.

\section{Lesbian Battering: Defining a Problem Outside the Legal System}

Lesbians are excluded from most constraints of the courtroom.

224. Battered women's adjustments to the separation may bring stress and emotions that can harm her on evaluation. Walker \& Edwall, supra note 200, at 140-41.

225. Sun \& Thomas, supra note 14 , at 569.

226. See StORDEUR \& STiLIE, supra note 81, at 26.

227. Sun \& Thomas, supra note 14 , at 574. 
This is not a fact that should be idealized; it grows out of oppression. They cannot marry. While they do confront custody litigation by former male partners, lesbians have not historically been able to sue each other for custody of children they coparented.228 Lesbians may also find it difficult to assert legal rights in shared property on separation. ${ }^{229}$ Homophobia in society deters many battered lesbians from invoking the legal system by calling the police for help or attempting to arrest the batterer. ${ }^{230}$ Even when lesbians seek protection through law, restraining orders may be unavailable against same-sex partners in some states. ${ }^{231}$ Because of this exclusion, the analysis of battered lesbians has developed in less direct relation to legal pressures than has analysis of heterosexual battering.

There are a few reported differences between lesbian and heterosexual battering. ${ }^{232}$ Lesbians report physically fighting back more often than women who are battered by men. ${ }^{233}$ Since heterosexual women also report fighting back against physical assaults, ${ }^{234}$ this difference in reporting may show a difference in what it is acceptable for women to discuss, or it may reflect an actual difference in women's responses to battering. ${ }^{235}$ The virtual absence of self-defense killings in lesbian relationships ${ }^{236}$ has also helped keep battered lesbians outside the legal system: battered woman syndrome is less emphasized in materials on lesbian battering in part because lesbians have not been raising claims of self-defense in court.

Lesbians have not only been excluded from the courtroom. Their stories as stories of women's lives have also often been excluded from

228. In three very recent cases, lesbians sought custody or visitation rights in court; in each case, however, no parental rights were recognized in the partner who was not the biological mother. Nancy S. v. Michele G., 228 Cal. App. 3d 831, 279 Cal. Rptr. 212 (1991); Curiale v. Reagan, 222 Cal. App. 3d 1597, 272 Cal. Rptr. 520 (1990); In the Matter of Alison D. v. Virginia M., 572 N.E.2d 27 (N.Y. 1991).

229. Nancy Hammond, Lesbian Victims and the Reluctance to Identify Abuse, in NAMiNo THE VIOLENCE, supra note 33, at 190, 196.

230. Hammond, supra note 229 , at $190,196$.

231. Ruthann Robson, Lavender Bruises: Intra-Lesbian Violence, Law and Lesbian Legal Theory, 20 GOLDEN GATE U. L. REv. 567, 576-81 (1990).

232. Walker, supra note 49 , at 75-76.

233. Id.

234. See generally Saunders, supra note 38 , at $90,103-08$ (self-defense is most common reason women exhibit violence).

235. Lydia Walker notes that possible explanations include "less size differential, less acceptance from the community to not fight back, [and] more permission from the community to talk about fighting back ...." Walker, supra note 49, at 76 (emphasis added).

236. Recently, a Florida court allowed the first use of expert testimony on battered woman syndrome in the defense of a lesbian who killed her batterer. See Robson, supra note 231, at 574 75. The jury convicted Annette Green of first degree murder despite the prosecution's acknowledgement that she had been battered and shot at in the past. Id. at 575 . 
the legal, ${ }^{237}$ psychological, and sociological literature. ${ }^{238}$ Despite the hard work of some lesbians in the battered women's movement, including staffing agencies and shelters, lesbians have often been excluded from shelters and from the support of the battered women's movement.239 Although this lack of recognition and scarcity of resources has caused harm to many lesbians, it left lesbian battering to be defined within an activist tradition close to the grassroots shelter movement and dedicated to supporting women.

Naming The Violence, the first book on lesbian battering, includes the stories of many battered lesbians. Compared with published narratives of heterosexual women's battering relationships, the lesbian narratives place more emphasis on the positive aspects of the relationship; the battered women seem more willing to explain, or possibly more in touch with, the positive feelings that drew them in and kept them involved:

I look back and can see that there was something good. It didn't start with violence and ugliness. It started with summer nights, two women in their early twenties trying to find a way to see each other. Both lived in households where it wasn't possible to be open about the relationship. Meeting at movies and bars until early in the morning - until finally one left her home. Nights of lovemaking, not enough sleep and feeling fine at work the next day - being relaxed and happy. I had found something that I never even knew existed. I never thought that there would be some one person for me, and I had now found her. I think neither of us doubted that we had found a lifetime relationship. The feeling of rightness was there....

And who is the monster in the next room who did this? She's just a woman like you who is feeling as upset as you are and is temporarily full of remorse. She is the only friend you have, the only one who seems to

237. See generally Leigh M. Leonard, The Missing Voice in Feminist Legal Theory: The Heterosexual Presumption, 12 WOMEN's RTS. L. REP. 39 (1990).

238. The stories of lesbians have been excluded from most fictional treatment of women's lives as well. In "Listening," the final story in Grace Paley's most recent book, the narrator, Faith, is in a car, stopped at a light, watching a man crossing the street and thinking warmly about his body. She speaks to Cassie, a friend sitting next to her who has not previousiy appeared in the book of stories, and asks, "He's nice, isn't he?" Cassie refuses to accept Faith's statement that the man is returning to "everyday life":

To whose everyday life, she said, goddamnit, whose?

She turned to me. . . . Listen, Faith, why don't you tell my story? You've told everybody's story but mine. I don't even mean my whole story, that's my job. You probably. can't. But I mean you've just omitted me from the other stories and I was there. In the restaurant and the train, right there. Where is Cassie? Where is $m y$ life? It's been women and men, women and men,.... Goddamnit, where the hell is my woman and woman, woman-loving life in all this? ... You let [our other friends] in [to your stories] all the time; it's really strange, why have you left me out of everybody's life?

Grace Paley, Later the Same Day 209-10 (1985).

239. See Hammond, supra note 229, at 190, 195-96 (on problems for lesbians in shelters and the shelter movement). 
care. The idea of leaving seems worse than if you try to stay and make it work and make sure it doesn't happen again. Bruises heal and resentment fades back into the routines of work, shopping, watching reruns of All Creatures Great and Small, and driving her to church on Sunday morning. ${ }^{240}$

In these stories, lesbians seem more willing to face the current duality of their memories and feelings. This does not necessarily represent a difference between lesbian and heterosexual battering. These stories are more like those I heard from heterosexuals whose stories are included in this article, which emphasized the complexity of the marriage relationship while trying to analyze the violence, than they are like most of the stories in the published material on heterosexual battering. ${ }^{241}$ Lesbians do not seem less hurt by battering relationships than heterosexual women. Rather, it seems likely that the editors simply excised less of this quality than do the editors of most social science research:

I fell in love with her because she was warm and loving and open. Her brilliance and clear political thinking dazzled me, as did her creativity - her artwork, her cooking, her carpentry, her ideas about raising children. Like me, she was Jewish and radical and understood the importance of making one's home in the country. She was responsive to our class differences in ways that surprised and delighted me. We had similar dreams of family and commitment, and fantasies of how we wanted to live. We often had hot, passionate sex. She bought me flowers, and chocolate, and crystals, and wool socks. She played a mean game of Pac-Man. She sang me love songs, and slow-danced with me in the living room. She did not do these things only at the beginning but throughout our relationship. Even when the violence was most frequent, she also expressed caring tenderness toward me.

I want you to understand that I stayed with her for the same reasons any woman stays with her lover - because I honestly and deeply loved her, and was honestly and deeply loved by her.

I also stayed because I had nowhere else to go . . . .242

The second major difference in this lesbian battering literature is the absence of blaming the victim. Historically, lesbians have at least at times shared the cultural stereotype of battered women as weak. Therefore, Naming the Violence and articles on lesbian battering recount an initial resistance to recognizing the problem and show early

240. Lisa, Once Hitting Starts, in NAMing THE VIOLENCE, supra note 33, at 37-39.

241. Donna Coker suggests that battered heterosexual women also tell complex stories that mix love, happiness, pain, and unhappiness, but that professionals working with battered women are often uneasy with the complexity of these stories. Conversation with Donna Coker, 1990.

242. Istar, supra note 33, at 164-65. 
acceptance of myths about lesbian abuse. ${ }^{243}$ Some women initially believed that only "bar dykes" engaged in violence, that feminist lesbians were not involved in battering relationships, and that only couples "strictly locked into butch/femme roles ha[d] a problem with violence."244

So stereotypes have indeed existed among lesbians. Yet when these attitudes emerged within activist, feminist communities they were promptly confronted. They do not define the literature, and therefore do not create more ongoing stereotyping of battered lesbians. Traditional stereotypes are largely absent: the voice of the conservative social scientist, the Freudian analyst, and the professional who blames the battered woman for failing to control her batterer, have been left behind. The analysis generated by a grassroots, feminist, activist community presents a more nuanced, less stereotyping, and less victim-blaming view than any other literature in the field.

\section{Power, Control, Autonomy, AND SeParation}

\section{A. Identifying Domination in Violence Against Women}

Battering is about domination: "Violence is a way of 'doing power' in a relationship,"245 an effort by the batterer to control the woman who is the recipient of the violence. ${ }^{246}$ This is not news. A review of the literature shows that the conception of battering as about powerrather than about incidents of violence or about the psychology of women who experience violence - has been present in some of the psychological and sociological literature for some time. ${ }^{247}$ A decade ago, Dobash and Dobash placed battering in the context of patriarchy and described it as domination: "The fact that violence against wives is a form of a husband's domination is irrefutable in the light of historical evidence."248 However, the emphasis on power comprised only one

243. Barbara Hart reported that when lesbian battering was first brought to light, battered lesbians were perceived as "weak sisters." Hart, supra note 50, at 14. This obviously reflects some influence of cultural stereotypes.

244. Ann Strach et al., Lesbian Abuse: The Process of the Lesbian Abuse Issues Network (LAIN), in NAMING THE VIOLENCE, supra note 33, at 88, 89.

245. STETS, supra note 64 , at 110 ("The men want to direct and determine how their partner behaves, and the way they do this is through violence. ... [T] he men use violence to dominate, control, and force the women to conform to what they want."). Id. at 109.

246. LEE H. BOWKER, BEATING WIFE-BEATING 7-9 (1983) (discussing the balance of power in families); SCHECHTER, supra note 94, at 219-24 (describing battering as a way to maintain control).

247. See generally Dobash \& DoBash, supra note 12 (patriarchy and domination key framework of study); Bograd, supra note 101, at 559 ("Violence such as rape and battering is a form of male control over women."); see also STORDEUR \& STILLE, supra note 81, at 20 (noting recent emphasis on power and control in writings of some authors).

248. DOBaSH \& DoBash, supra note 12 , at ix. 
thread in the literature and was intermixed with much work psychologizing battered women. ${ }^{249}$ Legal literature, in particular, has often ignored the interplay of power and control, domination and subordination in the battering relationship.

The quest for control underlying the enforcement of women's social roles is often hard to perceive. In a heterosexual marriage, if one partner does all the dishes and the other does all the driving - that is, if one is assigned all responsibility for household work and spends a substantial amount of time on this work, and the other has virtually all the mobility - this may not strike observers as the result of an exercise of power but merely as a "traditional"250 attitude in the relationship. A researcher describing such a relationship might perceive "traditionalism" on the part of the woman. If the researcher is already looking for indicia of "traditionalism" in the woman's behavior or life circumstances, ${ }^{251}$ the terms of the inquiry may construct the findings. The woman's apparent "traditionalism" might mask a more fundamental issue. For example, domestic work, or large numbers of children, will represent "traditionalism" in a woman only to the extent that they are not the man's choice. If they are his choice, both factors might indeed represent the man's attempt to control the woman.

Dobash and Dobash treat battering as part of a context and history of patriarchy in which violence and disapproval inflicted by society as a whole, as well as by individual men, enforced women's roles. ${ }^{252}$ In fact, batterers often justify their violence with complaints describing

249. GONDOLF \& FISHER, supra note 12, at 1-2; SCHECHTER, supra note 94, at 20-24 (discussing theories of victim provocation).

250. In her 1979 study, Lenore Walker called battered women "traditionalists" who "readily accept] the notion that 'a woman's proper place is in the home.'" LeNORE WALKER, supra note 40, at 33. Walker stated that battered women give up careers to make the batterer happy or accede to his need to possess her. The battered woman turns her money over to her husband, feels that income belongs to her husband, and goes out of her way to make the man feel he is head of the home even while she holds it together. Some women secretly save money and leave when they have enough to go. Id. at 33-34. Although Walker describes this as the woman's traditionalism, all these actions except the belief that her income belongs to the husband seem to reflect the man's traditionalism and ability to control the woman rather than establishing her traditionalism. In her 1984 study, Walker found battered women more liberal and batterers the "traditionalists." WALKER, SYNDROME supra note 110, at 148.

251. For example, PAGELow, supra note 102, at 105-44 first hypothesizes "traditionalism" in both men and women in battering relationships. She then goes on to interpret even contradictory data as "traditionalism." Variables presumed to show "traditionalism" include: "numbers of children" and "secondary battering cohabitation" (continuing to live with the batterer after the first incident of violence). Id. at 127. When Pagelow's data show that women with more children, and especially more young children, stayed in relationships longer than other women, she interprets this as evidence of a belief in the importance of two-parent homes, rather than as a reflection of the difficulties of leaving or the low earning power relative to child care costs of these women. Id. at 141-42. The researcher's hypothesis of "traditionalism" is subtly transformed to support a finding of traditionalism.

252. DoBash \& DobaSh, supra note 12, at 47-96. 
the woman's insufficient fulfillment of household responsibilities and social role. ${ }^{253}$ The energy required to maintain that division of labor may go unnoticed when the expectations are most shared and enforced by social norms, and even by the actions of the state. ${ }^{254}$

Then we went to get the wedding license.

We took our blood tests and identification down to the big state office building ...., filled in some forms, and handed them to the clerk. She ... showed us what the minister would sign and gave us a little pamphlet on the "Louisiana Community Property Law."

Then she turned to me and said, "And these are for you." She handed me a nylon mesh bag with a tag attached that said, "For the Bride." It had samples of Tide, Joy, Spray'n Wash [detergent for clothes, detergent for dishes, stain remover for clothes], Windex, PAM $\ldots$ and other household products I don't remember. I said, "You've got to be kidding." And she said, sweetly, "No, these are for the bride."

The congruence of expectation by heterosexual batterers and society in general may be one reason lesbian battering has been understood as concerned with power. The expenditure of energy that goes into controlling a loved one may be more perceptible as an exercise of power when the control that is sought is less completely in accord with social expectation. ${ }^{255}$

While early studies assumed - and looked for - "traditional" attitudes in battered women, other studies found that battered women were likely to have less traditional attitudes regarding women's roles in the family, but that battering men had more "traditional" attitudes. ${ }^{256}$ Consistent with this, Bowker found that men's participation in male networks increased the likelihood that the men would have rigid attitudes regarding male dominance and enforce these attitudes with

253. OKUN, supra note 107 , at $69-70$ (batterers justify assaults with criticisms of wives' household tasks); STETS, supre note 64, at 71, 95-98.

254. State actions enforcing women's roles include refusal to enforce TROs and returning women to abusive situations, generations of home economics education for girls and not for boys, and giving out cleaning supplies as in the narrative below. Additional examples are public housing policies that define women fleeing abusive relationships outside the category of those homeless "through no fault of [their] own," see LEE ANN HOFF, BATTERED WOMEN AS SURvivors 195-201 (1990), and public housing policies that give the battering man possession of the apartment if his wife leaves. Conversation with Kim Hanson, 1990.

The following incident took place in Louisiana in 1976. I have heard of other women who were given with their wedding licenses either actual cleaning supplies or coupons for cleaning supplies in California during the late 1970s and in the midwest at various times. (It is not obvious which gift the women considered more offensive).

255. This would not necessarily link "role-playing" in lesbian relationships with violence; in fact, no such correlation emerges in the reports on lesbian battering. Barbara Hart, Violence in Lesbian Relationships 2 (unpublished manuscript in materials on lesbian battering distributed by W.O.M.A.N., Inc.) (on file with author); id. at 3 (denial fed by idea that only violent lesbians are those "who hang out in bars or are into playing butch").

256. See, e.g., WALKER, SYNDROME, supra note 110, at 8. 
violence. ${ }^{257}$

Focusing on the struggle to control the woman that lies at the heart of battering makes sense of many apparently discrepant research findings. Questions of money, status, and education could trigger acute insecurities regarding power in relationships. In many violent relationships the woman has a higher educational level and comes from a higher social status than the man. ${ }^{258}$ Kersti Yllo found battering highest in states where women's power and status were highest relative to men's. ${ }^{259}$ On the other hand, Bowker's study of women in formerly violent marriages showed that women with higher current incomes were less likely to have been severely beaten or beaten while pregnant, and found no correlation of violence with the woman's higher or lower social class. ${ }^{260}$ In lesbian relationships, some experts have found that the battered lesbian is more likely to be the breadwinner or primary supporter of the household, ${ }^{261}$ however, another commentator observed higher educational and social status among batterers. ${ }^{262}$

If the central question in battering were the woman's acceptance of violence, it would be difficult to explain both the widespread finding of women's higher education and status, and the inconsistency in some of this data. However, if we emphasize the batterer's struggle for control and look at battering as a (violent) point on a continuum of domination in relationships, then these findings make sense in two ways: first, factors that increase the woman's independence and autonomy might

257. BowKER, supra note 246, at 54. Bowker had expected to find greater social isolation among battered women - reflecting some assumption that society disapproves violence as well as the assumption that battered women have been isolated from society - but instead found increased social embeddedness among the men, with concomitant support for male dominance.

258. WALKER, SYNDROME, supra note 110, at 11, 16, 156, 158, 160; see also Molly Chaudhuri \& Kathleen Daley, Do Restraining Orders Help? Battered Women's Experience with Male Violence and Legal Process, in Domestic Violence: The Changing Criminal Justice RESPONSE (Eve Buzawa \& Carl Buzawa eds., forthcoming 1992) (tentative title) (stating that violent men had fewer years of education than their wives). Walker notes that it is said most women marry at or above their own social class, while most men marry at or below theirs. She therefore finds this a sharp break from the usual pattern in marriage and a noteworthy characteristic of battering relationships. LENORE WALKER, supra note 40, at 11, 17.

259. Yllo, supra note 101, at 28,31 (noting that this finding contradicted her assumptions about traditionalism in relationships).

260. Women with higher current income also were less likely to have suffered marital rape. BowkER, supra note 246 at 50-51. None of Bowker's findings permitted a comparison with marriages in which the husbands had higher status. His findings did not support the theory that battering was a form of compensation for other forms of maintaining power in a relationship. Id.

261. Domestic Violence By and Against Women: An Interview About Lesbian Violence, excerpts from an interview by KALX, Berkeley, California, with Susan Jan Hornstein, Exec. Dir. of Western Center on Domestic Violence, and Naomi Porat, Administrative Coordinator at W.O.M.A.N., Inc. and facilitator of a battered lesbian support group, in materials on lesbian battering collected by W.O.M.A.N., Inc., supra note 255, at 2 .

262. See Hart, supra note 255, at 3 (noting battering lesbians of more privileged background). 
make additional control moves, including violence, more likely; second, power and control struggles may be triggered by many factors within a relationship and therefore could also be consistent with dominance by the partner with greater resources.

James Ptacek, who worked with batterers, and Jan Stets, who worked with couples, found control an ongoing issue in battering relationships. Both Ptacek and Stets describe men as using violence to control the woman. ${ }^{263}$ The instrumental goal of control is made excused or made invisible by the fact that the man appears to be out of control himself: both men and women perceive violence as caused by the man's loss of control over his actions. ${ }^{264}$ However, both Stets and Ptacek questioned the man's apparent loss of control. Ptacek emphasized that batterers' actions were selective, and that their descriptions of their own actions reflected conscious choices. ${ }^{265}$ Stets found that the men selectively "lost" control in order to achieve the goal of controlling the women, but differed from Ptacek in emphasizing the role of the woman's response as minimizing the negative results for the man of his loss of control. ${ }^{266}$ Other scholars also have emphasized that "a major reason for the use of marital violence is to increase one's power over a mate."267

Recognizing the batterer's attempt at domination as the key to battering relationships allows a focus on his motivations rather than the psychology of the victim. A study of the effectiveness of temporary restraining orders in relation to several different goals ${ }^{268}$ found success

263. Ptacek, supra note 48, at 147-49; STETS, supra note 64, at 101-11, 121-31.

264. To both the man and the woman in the relationship, the man's loss of control over his actions appears to cause his violence. Ptacek, supra note 48, at 153-54. See generally STETS, supra note 64, at 54-68. Indeed, the idea that the man cannot control his anger appears throughout sociological and psychological literature. Id. at 11-12 (discussing literature); Ptacek, supra note 48, at 152-54 (discussing literature). The man will use this apparent lack of self control to carry out his domination of the woman, and will also use it to "excuse" his domination.

265. Ptacek sees violence as instrumental. "[This] loss of control is substantially contradicted by the batterers' own testimony. While the men claim that their violence is beyond rational control, they simultaneously acknowledge that the violence is deliberate and warranted." Ptacek, supra note 48, at 153.

266. See generally STETS, supra note 64, at 101-11. Stets criticizes Ptacek's instrumentalism for neglecting to ask what makes batterers discontinue particular violent incidents. Id. at 61 . In her discussion of battering relationships, Stets emphasizes the woman's responses as well as male control goals. Id. at 95-100 (emphasizing woman's acts as cues). This brings her somewhat closer to family systems theorists and to Pagelow's emphasis on the woman's response to violence. Stets sees instrumental violence as emerging over time in the course of a battering relationship. Id. at 103.

267. BowkER, supra note 246, at 134. Power and control were also central contested issues in the majority of the formerly violent marriages in Bowker's study. The cessation of violence was associated with decreased male dominance in many of the relationships. Id.

268. The orders are more effective for some goals than for others. Chaudhuri \& Daley, supra note 258 . 
in reducing the likelihood that the man would batter again dependent on the man's circumstances and motivation, not the woman's. ${ }^{269}$ Similarly, a study of interspousal homicide revealed that the men could not cope with their bondedness with women. Unable to face their dependence on the women they loved, the men struck out against the women when they felt abandoned. Spouse homicide resulted from "individuals attempting to solve by their action the riddles of culture that the events of life force on them."270 As men, they could not be dependent on their women, yet they could not face abandonment. This finding emphasizes the importance in battering relationships of the man's capacity to confront his own feelings and the danger of his need for control.

The focus on the batterer's need for control also reconciles another discrepancy in battering studies. Bowker reports that a threat to leave the batterer may be very effective at ending the violence. ${ }^{271}$ However, other studies show that separation often triggers escalated violence. ${ }^{272}$ The same behavior - threatening to leave the relationship - might prove extremely effective or tremendously dangerous for women. The difference will depend on the men with whom they are involved. If the key to whether the violence escalates lies in the man's capacities, then any system examining the woman's behavior and psychology will poorly track the danger she faces - unless we consider her the best judge on this issue. 273 Courts are ill-equipped to measure retrospectively the man's capacity to "solve ... the riddles of culture" without homicide, or the persuasiveness of his threats to the woman. ${ }^{274}$

A focus on control also makes sense of the particular situations of

269. Id. Several attributes made it more likely that the man would abuse the woman again: prior criminal history, unemployment or part-time employment, and drug or alcohol abuce.

270. George Barnard et al., Till Death Do Us Part: A Study of Spouse Murder, 10 BULL. AM. ACAD. Psychiatry \& L. 271, 279 (1982).

271. BOWKER, supra note 246 , at $65-67,123$.

272. Ellis, supra note 21, at 408.

273. Therefore, we need to vest evaluation of the man's violent potential in the woman. Her understanding of the process of violence and the man's motivation may not be perfect: violence may appear out of control to the women even when men actually retain some ability to control their actions; women also may perceive men's actions after violence as contrition or determination to reform which the men either do not experience or will not admit openly. STETS, supra note 64 , at 127. However, the instrumental nature of his violence makes her, the target, the closest observer. She has more resources to measure his violent potential than any outside observer and the woman is best placed to assess the man's potential dangerousness, because she is most aware of the times and manner in which violence may occur. Barbara Hart, Beyond the "Duty to Warn": A Therapist's "Duty to Protect" Battered Women and Children, in FEMINIST PeRspectives ON Wife ABUSE, supra note 31, at 234, 240.

274. This is true whether the legal issues relate to her injury or death, or his. Barbara Hart has therefore drafted a lethality assessment questionnaire that aims to help professionals elicit from the battered woman information relevant to her informed assessment of her own situation, rather than replacing her assessment with their own. See id. 
women with children. Women with children often give their children as the reason for their action - whether they have acted to stay, leave, or return to a relationship. ${ }^{275}$ With the focus on control, difference makes sense: different male tactics, different types or frequency of violent episodes, might work to keep a woman with no children in a relationship than would work with a woman with children, ${ }^{276}$ since women often leave when they perceive either physical or emotional danger to their children from the violence. 277 Controlling a woman with a disability - or whose child has a disability - may also have its own particularities of action within relationships. Fear of custody actions may also facilitate the control of women who believe a court might be unsympathetic to them.

Perhaps most important, identifying power and control as the struggle within a relationship enables women to make sense of our own experiences.

I don't even talk baby talk to my kid like I did to my first husband. It reduced me - I was not supposed to think. I was not supposed to have any ideas. I was not supposed to be a person.

One thing that made it so difficult was that before hooking up with him, I was a leader in the community. I was doing a lot of anti-war organizing work. I had my own apartment, my own life. I was an independent person, I'd been on my own for years. I had not moved from being dependent on my family to the marriage. I was a person who knew how to take care of myself, who had made it on my own.

To this day, I don't understand it. I'm usually not a person who's lost for words, I'm usually not a person who falls to pieces. I get ambushed by the Klan, and I have the clearest head of anybody around. But that certainly wasn't the case in that marriage.

This woman recognizes her own strength and independence, and finds it hard to reconcile these qualities with the degree of control her husband succeeded in exercising through a few violent episodes followed by explicit and implicit threats. In fact, these could have been the qualities that made her husband feel threatened and turn to violence as a means of control. For years, she described the unhappiness of the marriage to friends without describing her husband's violence. She described personal problems frankly but could not communicate the experience of violence without diminishing her own self-esteem. She

275. DOBASH \& DOBASH, supra note 12 , at 148.

276. Pagelow notes that the presence of young children can be a very strong factor that keeps women in their relationships; most women waited to leave until their children were at least past infancy. PAGELow, supra note 102, at 142.

277. "Her decision to terminate the relationship is more often motivated by concern for her children than by any real appreciation of the unacceptability of the abuse she has experienced." Anne McGillivray, Battered Women: Definition, Models and Prosecutorial Policy, 6 CAN. J. FAM. L. 15, 22 (1987); see also DoBash \& DoBASH, supra note 12, at 148. 
could have described his actions as inappropriate attempts at controlling her without incurring the same humiliation.

Focusing on control lets women understand our lives without stigma by describing battered women's experience as part of all women's experience. A focus on control places the sensational, severely violent cases on a continuum of violence that makes sense whether the woman or the batterer is the defendant, whether it is a criminal or a civil case, whether or not the case appears likely go to court. Therefore, a focus on control provides the link between the woman's experience in her relationship and the experience of other women she learns of through the press or other media - an essential step toward her informed decisionmaking and toward remaking women's cultural concepts of domestic violence. Finally, by sorting and explaining women's experience in ways that apply across the varied legal postures in which domestic violence comes to public attention, a focus on power and control provides a coherent understanding of the experience of women in different situations: women experiencing varying kinds of attack by batterers in the attempt to exercise power and control; women of varying social status; women with or without children; women perceived as "leaving" or "staying."

To bring women's experience into law and make it more comprehensible to women ourselves, we need litigation strategies aimed at exposing the power and control at the heart of battering. One example of such litigation is the lawsuits brought since the 1970s that expose the failure of police to enforce temporary restraining orders. ${ }^{278} \mathrm{We}$ need more such creative approaches that expose the complicity of the state and society in the control of women in violent marriages. After being physically threatened and emotionally attacked for my failures at housework, I have often longed to sue the state actor - the clerk processing paperwork for marriage licenses - who by handing me cleaning supplies put the state's imprimatur on my husband's conception that this would be my job. Joyce McConnell describes battering relationships as involuntary servitude in violation of the Thirteenth Amendment - an analysis consistent with an emphasis on power. ${ }^{279}$ Below, I develop an example of such a strategy, emphasizing the attacks on women's attempts to separate from violent relationships to help expose issues of power and control in both law and culture.

278. See, e.g., Bruno v. Codd, 393 N.E.2d 976 (N.Y. 1979); Balistreri v. Pacifica Police Dept., 855 F.2d 1421 (9th Cir. 1988), amended on other grounds, 901 F.2d 696 (9th Cir. 1990); Thurman v. City of Torrington, 595 F. Supp. 1521 (D. Conn. 1984).

279. Joyce McConnell, Beyond Metaphor: Battered Women and Involuntary Servitude, 4 YALE J.L. \& FEMINISM (forthcoming). 


\section{B. "Who Says She Didn't Leave?": 280 Challenging Perceptions of Separation and Autonomy}

The "shopworn question"281 persists in the cases, legal scholarship, and social science literature. It reveals several assumptions about separation: that the right solution is separation, that it is the woman's responsibility to achieve separation, and that she could have separated. The question "why didn't she leave" is actually an objectifying statement that asserts that the woman did not leave. Asking this question often makes actual separations disappear.

If we ask the woman, "What did you do?" the answer very often turns out to be, "I sought help." Edward Gondolf, who studied women's helpseeking behavior, found that women responded to abuse by seeking help from both formal and informal sources. ${ }^{282}$ The more apparent it became that the batterer would not change, or the worse the abuse became, the greater diversity the women showed in their efforts to find help. ${ }^{283}$ Gondolf concluded that it was the helping professions, rather than battered women, that were afflicted with "helplessness." He described battered women as "survivors" who developed self-transcendence to allow them to go on. 284

When we ask the woman, "Exactly what did you do in your search for help?" the answer often turns out to be that she left - at least temporarily. In Gondolf's study, more than seventy percent of the women had left home at some time in response to violence, though only fourteen percent had gone to shelters. ${ }^{285}$ Of the women Walker studied, about one quarter left temporarily after each battering incident. 286 Walker does not indicate whether the intention of these women as they left was temporary or permanent separation or whether they were in fact uncertain when they left.

Some social scientists have criticized the assumption that the woman has a responsibility to - on her own - successfully accomplish a separation in her family on her first attempt to do so. ${ }^{287}$ This assump-

280. This is my paraphrase of Lewis Okun's phrase, "Who says she does stay?" OKuN, supra note 107 , at 56.

281. Ann Jones, The Burning Bed and Man Slaughter, 9 WoMEN's RTS. L. REP. 295, 296 (1986) (book review).

282. GONDOLF \& FiSHER, supra note 12, at 18, $27-28$ (describing several studies showing helpseeking); see also WALKER, SYNDROME supra note 110, at 26 ("As the violence escalated, so did the probability that the battered woman would seek help.").

283. GoNDOLF \& FISHER, supra note 12, at 92-93.

284. Id. at 22-23, 99.

285. Id. at 77-78.

286. WALKER, SYNDROME, supra note 110 , at 26.

287. OKUN, supra note 107, at 56; GONDOLF \& FISHER, supra note 12 , at 82-83. 
tion ignores the woman's substantial ties to her current family structures. Her initial goal in separating may have been to improve her family structure rather than end it. Participation by the batterer in a counseling program is a very significant factor in predicting a woman will end a separation, since his participation tends to increase her hope for safe return. ${ }^{288}$ Therefore, some experts recommend the credible threat to leave or attempt to separate as a measure for women who seek to end the violence against them but wish to preserve their relationships. ${ }^{289}$ Finally, the assumption that the woman's first separation should be permanent ignores the real dangers that the man will seek actively - and sometimes violently - to end the separation. ${ }^{290}$

When the woman is asked, "what happened to you when you left?" we discover the lack of available resources. Shelters are unable to fill all the women's needs; when shelters make referrals to social service agencies, the agencies are often inadequate. Gondolf therefore identified "learned helplessness" among the helping professionals to whom women turned for assistance. ${ }^{291}$ Neighbors, friends, and family may be sources of help, but often they too leave the separated woman without assistance:

It was a day he was supposed to visit the children, but he didn't come. About nine o'clock at night, I heard a pounding noise downstairs. I heard him shout that he was bleeding, "Help me, help me."

$\mathrm{He}$ had broken one of the glass panes in the door and wouldn't stop hitting it. When I opened the door, he fell part way through and lay there on the floor, moaning. He had been in a bar fight around the corner from my house, 10 miles from his own. He had broken a glass door at the bar and come back to the house. He said the police were after him. I thought he was crazy.

I went to the phone - I didn't want to leave the room or take my eyes off him, and called my closest friends, a couple who lived a few blocks away. The man answered the phone. I said urgently that my husband was there and that I needed this friend to come over right away. He said OK and hung up. Fifteen or twenty minutes passed, and then his "wife showed up. She said, "Allan wasn't going to come. He didn't see why you were bothering us. But I figured, if you had called, someone ought to check up and see what was going on."

The police arrived. They had traced his car to our house and followed a trail of blood to our door. They weren't going to arrest him.

288. GONDOLF \& FiSHER, supra note 12, at 87.

289. BowKER, supra note 246, at 65-67, 123 (husband's fear of divorce ended violence); see also Littleton, supra note 34 , at 52 (criticizing the current legal system for offering actual separation as the only remedy against violence).

290. See infra text accompanying notes 295-302.

291. GoNDOLF \& FiSHER, supra note 12, at 22-23. 
When I asked, they waited for his brother-in-law to come pick him up. ... Finally everyone went home.

It was so frightening that a man I had known for five years, who knew how my ex-husband had been, had actually lied to me and said he was coming, then been willing not to show up. They lived four blocks away! My mother told me I should talk to the neighbors, try to line up more help for next time. So I went to my next door neighbor the next day and began, "About the noise last night ...." He looked at me very fiercely. "What noise? We didn't hear anything/" For a minute, I thought he had been running his air conditioner and really couldn't hear. It was a small quiet street in a family neighborhood. I said, "When the police came ...." He glared at me again and interrupted. "We didn't hear a thing!"

Finally, we ask the woman herself about the key behavior of the violent partner whose behavior actually defines her state as a "battered woman." We say, "What did he do when you left?" At that moment, we will hear the story of the attacks on her autonomy; all we need to do is listen. Often, a woman has left several times before she finally ends a marriage. ${ }^{292}$ Or, she may have been restrained from leaving by violent or coercive means: by being held prisoner in her home, by being threatened with custody suits, by having her savings taken away before she could depart. ${ }^{293}$ One feminist writer in the field recently wrote without apparent irony,

[He] always found ways to get her to come back. He would come and tell her how sorry he was and how much he loved her; he would promise never to do it again. And she wanted to believe him .... When she wavered and it appeared his pleas and promises might not work, he would threaten to kill her if she refused to come home, threats which his past behavior gave her every reason to take seriously. ${ }^{294}$

There are many aspects to redefining separation: we need to comprehend the related power and control issues common to continuing relationships and to separation, rethink the implicit burden on the woman to leave her home and risk losing her family, and change our perceptions of what it means for her to separate. Finally, we need to reckon with the dangers she faces. The rest of this article discusses the assault on women's attempts to separate. The story of the violent pursuit of the separating woman must become part of the way we understand domestic violence to help eliminate the question "Why didn't she leave?" from our common vocabulary.

292. See, e.g., DOBASH \& DOBASH, supra note 12, at 144-47 (discussing the woman's leaving, returning, and leaving again as a process of pulling away from the commitment of marriage and establishing an autonomous life despite insufficient resources to support a family).

293. See, e.g., OKUN, supra note 107, at 69 (citing several studies describing women's secret savings to allow them to leave abusive relationships).

294. GILLESPIE, supra note 11 , at 2. 


\section{Strategies for Change and the Redefinition of Separation}

How can we bring the issues of power and control into the courtroom? Can we explain how differently men and women may perceive control?

I once told a man in a bar that if I was attacked by a man and could somehow fight him off enough to run away, I would consider that I had won the encounter - that I had beaten him. The man said, "No, no, you had to run away, therefore you lost." I said, "No, I was safe, I was unviolated, and therefore I won, I preserved myself." That's what we have to deal with: the way we cope may be very successful, useful, and good - as women - and you can count that as a success. A man could not count refusal to show fear as success. Because he was able to control you as he saw it, show rage, he may think he was successful in that situation as well.

This reflection on the ways men and women perceive control has important implications for the concept of separation assault. The woman defines successful flight from attack as a victory. The man insists that this is not victory but defeat. The persistent accounts of the difficulty women encounter on separation, especially condemnation from their families and employers, suggest society's perceptions track men's interpretations: leaving a violent relationship is widely perceived as an admission of defeat rather than victory. The ways in which separation is similar to the escape from impliedly sexual assault discussed in the quotation above are generally not cognizable at all in law or social discourse. The dangers women face in the effort to separate make separation a victory. These dangers need a name.

Law assumes - pretends - the autonomy of women. Every legal case that discusses the question "why didn't she leave?" implies that the woman could have left. We need to challenge the coercion of women's choices, reveal the complexity of women's experience and struggle, and recast the entire discussion of separation in terms of the batterer's violent attempts at control.

Although it is still focused on successful and final separation as the key event, the recently developed term "postseparation woman abuse" begins to grapple with the problem of revealing the issue of power and control in women's experience of violence. ${ }^{295}$ At least half of women who leave their abusers are followed and harassed or further attacked by them. ${ }^{296}$ In one study of interspousal homicide, ${ }^{297}$ more than half

295. See, e.g., Ellis, supra note 21 , at 410 .

296. BROWNE, supra note 3, at 110.

297. Until we begin gathering on a broad scale statistics that speak to separation, we are more likely to know if women kill spouses than if men do, since the status of a woman victim as a former partner of the man may or may not appear in police reports and statistics. Since women 
of the men who killed their spouses did so when the partners were separated; in contrast, less than ten percent of women who killed were separated at the time. ${ }^{298}$ Power and control are crucial here in several ways. Men who kill their wives describe their feeling of loss of control over the woman as a primary factor; most frequently, the man expresses the fear that the woman was about to abandon him, though in fact this fear may have been unfounded. ${ }^{299}$ The fact that marital separation increases the instigation to violence ${ }^{300}$ shows that these attacks are aimed at preventing or punishing the woman's autonomy. They are major - often deadly - power moves.

However, the term "postseparation woman abuse" fails to capture the many cases where violence occurs in response to the decision itself: the essential attack is on the woman's autonomy. Barbara Hart notes that "[t]he decision by a battered woman to leave is often met with escalated violence by the batterer."301 When the decision, rather than actual separation, triggers the attack, the circumstances of the violence may not reveal the assault on separation: the couple may still have been living together, and the attack may have taken place inside their mutual home - yet the attack may have been a direct response to her assertion of the will to separate or her first physical moves toward separation.

\section{Defining Separation Assault}

To expose the struggle for control, we should recognize the assault on the woman's separation as a specific type of attack that occurs at or after the moment she decides on a separation or begins to prepare for one. I propose that we call it "separation assault." The varied violent and coercive moves in the process of separation assault can be termed "separation attacks."

Separation assault is the attack on the woman's body and volition in which her partner seeks to prevent her from leaving, retaliate for the separation, or force her to return. It aims at overbearing her will as to where and with whom she will live, and coercing her in order to enforce connection in a relationship. It is an attempt to gain, retain,

kill partners with whom they are still living, this is more likely to be detected as interspousal violence.

298. Barnard et al., supra note 270, at 274; see also Franklin Zimring et al., Intimate Violence: A Study of Intersexual Homicide, 50 U. CHr. L. REv. 910 (1983).

299. Barnard et al., supra note 270, at 224.

300. Ellis, supra note 21, at 408.

301. Hart, supra note 273 , at 240 (emphasis added). 
or regain power in a relationship, or to punish the woman for ending the relationship. It often takes place over time.

Attacks on separation pervaded the stories of the women who spoke with me. The announcement of intent to separate may be fraught with grave danger:

He was on strike for the second time in a year. I was pregnant with the second baby in a row. There was absolutely no money. Every day, he yelled at me for a long time - an hour, two hours - about how awful I was. . . . I remember how desperate I felt and how much I needed it to stop.

[One day, when he seemed receptive, she told him it had to stop.] $\mathrm{He}$ wouldn't listen. I said I couldn't live like that anymore and would leave if he didn't stop. He kept saying I couldn't leave because we didn't have enough money to support two households. I said that only his failure to listen could make me leave - I couldn't live like that anymore... . .

Suddenly he lost his temper.... He stormed upstairs, and I heard him pushing around in the closet. I thought, "That's funny. It sounds like he's getting the gun." And I didn't sit down or move - I stood in the middle of the living room floor and waited. He came down the stairs shouting and I saw that he really did have the shotgun. I knew it was fully loaded. I remember making the conscious decision that this was different than waiting through other outbursts, and that any argument would be deadly.

I turned around and ran out the front door screaming that I was pregnant and ran up the landlady's front steps. I was going to call the police. But I realized that I had heard the baby crying upstairs. All the noise had wakened her from her nap. I couldn't believe he would shoot his child, but I didn't know why he'd gotten the gun, how well he actually knew what he was doing ... how irritating her crying might be. I turned around and went back into the house. I could hear him putting the gun away in the closet. We got to the baby at the same moment.

I dressed her, put on my own clothes, and left. I had $\$ 1.60$ and no more money coming for several days. I took the better car. I drove away without knowing where I was going to go. (Emphasis added.)

Although women's stories recount many attacks triggered by separation, the nature of the attack on separation itself generally goes unrecognized. Similarly, women describe coercive violence escalating after separation - violence clearly aimed at denying their autonomy - in terms that show they may internalize self-blame rather than clearly identifying the man's attempt at control:

We had been separated nine months. I came home late one night with a date. I was sitting in the living room playing backgammon with this man, when I saw the car drive up. I thought of sending [my date] home, but I didn't, maybe because I knew I needed help. Maybe I was just defiant.

He knocked. I kept the chain lock on the door, and I told him to go 
home. He wouldn't leave. He rang the bell for fifteen minutes without stopping. I woke up my roommate, and she disconnected the doorbell.

He started pounding on the door. He broke it in and started a fight with this man. I'm sitting there in horror, watching it - the door broken down, them crashing around the living room .... The kids woke up. I sat them on the couch with me.

Then - he was very drunk - the fighting stopped. It was pretty short. But it took two hours to try to get him to leave. He ran around with a butcher knife ... he left the house with it. Finally, I could call the police. Then I don't know if he came back in with the knife - I think he came back after the police were called. The kids were on the couch screaming and crying, I was trying to take care of them.

The police saw the door leaning in the middle of the room, the room trashed and crashed. [They refused to arrest him because "his name is still on the lease."] They told me to get a TRO the next day.

I was left to put the pieces back together. And you know what I did? I went and made love to that guy who was there. I had to - anything to not think. I feel kind of whorish about that - I hardly knew him. I didn't even want to, it was 6 a.m., my whole body hurt, I was just exhausted. It seems bizarre.

So I went and got the TRO. Now when I talk about it, I feel like I should be more upset about it.

No, nobody in the building heard anything. They're afraid to. They didn't hear him break down the door, or even ring the doorbell for fifteen minutes in the middle of the night .... . None of them heard anything!

This woman's sexual choice seems at least partly explicable as a reassertion of control over her body, over her choice in men, and as a specific denial of power to the ex-husband who had put her through so much pain. Her husband might break down the door, but she could affirm her separation again.

Women describe protracted and inventive attacks on their moves to separate:

Well, leaving took months. When I first left, I really didn't even know I was leaving the marriage. I was just going to California to get the car that he had left there. But being on my own again, and away from him, I began to regain some of my self-confidence, and I liked it. And people liked me.

But then he came out to California to reclaim me. And totally humiliated me in front of my friends. ["Humiliation" including forcing her to have sex - essentially committing marital rape - in the back of a Volkswagen van while two other men were in the vehicle.] I was scared of him, I was still scared of his violence. As strong as I had been when he wasn't around, as soon as he came around, I would fall back into the baby talk, I would fall back into the patterns.

Then we got back to Michigan, and I left again and went to stay with my friends. I was in Ann Arbor, and I had a fever. And he came to check on me... He got my heirloom ring off my finger that night. The 
ring that all my life I felt separated me from poor white trash. The ring that my great-great-grandmother brought over from Germany when she fled the failed revolution of 1848. I never saw that ring again. He threatened to burn down the house I was staying in, but he was satisfied when I gave him the ring because he knew I would come back for it.

I went back again [because he promised to return the ring]. I never got it. And then when it was time for my friends to leave town, they came to our house in Detroit, en masse, and said it was time to go. And I picked up, and I walked out. "Well, it's time to go, we're leaving." And I went.

Some of these attacks on separation will go unnoticed until we begin identifying them specifically:

I felt guilty, so I went back. That lasted a month, until Valentine's Day .... Finally, on Valentine's Day, he was throwing things. He was throwing glass - I was barefoot - it was totally absurd. I was being held prisoner in my bed by glass!

I picked the kids up, scrunched my feet so they were under the glass, dragged my feet over the floor so they weren't getting cut too much, and made it out of the house.

One of the best-known battered women in America is Francine Hughes, whose story was told in The Burning Bed. The trial and movie brought the atrocities against her to public attention, but there was little cultural attention to the lessons of her search for autonomy:

Hughes' entire marriage - and her life after divorce - was a search for the exit. [Family], in-laws, friends, social services, police, sheriff's office, county prosecutor - she tried them all. And even when Mickey Hughes came within moments of choking her to death or cutting her throat, no one helped. ${ }^{302}$

We already recognize the danger of the attack on separation pragmatically and intuitively. This is a major reason for the existence of shelters, which protect women against attacks while giving them a place to live. It is the main reason that shelter numbers and addresses are not listed in telephone directories. It is the main reason women seek protective orders. It fills the pages of our newspapers with accounts of attacks on women by their separated husbands. Although we see this attack everywhere, we cannot analyze it until it has a name.

\section{Naming Separation Assault and Understanding Battering}

Naming women's experience is an important component of feminist struggle for social and legal change. ${ }^{303}$ Naming separation assault has the potential to change consciousness in a manner comparable to 
the concept of "date rape." "Date rape" and "separation assault" name phenomena women know from our own experience, but which remain invisible without names. ${ }^{304}$ These terms do more, however, than merely identify hitherto unnamed experience. Each term identifies one aspect of a common attack on women in a way that illuminates the whole picture. Date rape is not all rape; separation assault is not the whole story of battering. Yet in each case, the act of identifying and describing the formerly invisible part transforms our understanding of the formerly misunderstood whole.

"Date rape" was a term women recognized when we heard it. It helped popularize a redefinition of the concept of rape: "Acquaintance rape is forced, manipulated or coerced sexual intercourse by a friend or an acquaintance. It is an act of violence, aggression and power."30s Naming date rape helped move discussion of rape past its old starting point, an image of sexual violence committed by a stranger. The concept of date rape thereby allowed women to recognize that the assault they had experienced was, in fact, rape.

Naming and recognizing separation assault will make women's experience more comprehensible to ourselves as well as to the legal system: We know it when we hear it. Attacks on our autonomy are one point at which women can - without stereotyping or invoking the likelihood of denial - locate our own experiences and those of our sisters and friends on a continuum of control attempts that includes those extremes of violence that become known through the sensational cases covered by the press. Women may find the current terminology of battering stigmatizing or alienating, yet be willing to admit that they have experienced inappropriate control attempts by their partners, including assaults on their capacity to separate from "bad" marriages. Exposing control attempts reveals the woman's struggle, rather than defining her according to the behavior of her assailant.

The name "separation assault" also helps women understand our own long-term reactions to violence or to the threats accompanying the end of relationships. Shelters and counseling provide short-term separation assistance, but the impact of separation assault goes on: Fear of an ex-husband becomes part of a woman's life.

304. That which has no name, that for which we have no words or concepts, is rendered mute and invisible; powerless to inform or transform our consciousness of our experience, our understanding, our vision, powerless to claim its own existence.

Barbara DuBois, Passionate Scholarship: Notes on Values, Knowing and Method in Feminist Social Sciences, in ThEORIES of Women's STUdIEs 105, 108 (Gloria Bowles \& Renate Duelli Klein eds., 1983), quoted in Kelly, supra note 31, at 114. Another example of an assault we must come to recognize is "sexual harassment." Id. at 115.

305. American College Health Association, Acquantance Rape: is Dating DANGEROUS? (1987). 
The first year I was at Stanford, I saw The Burning Bed. I couldn't not watch it, and I couldn't stop watching. I was so scared when it finished. I started calling my ex-husband. It was the middle of the night there. I kept calling him frantically for over an hour. He wasn't home. I became convinced he was on his way there with a gun on a plane. I was sure he would kill me.

I locked the door and got in bed with the kids and shook all night, waiting for him. It was two and a half years later. I was two thousand miles away.

This woman had withstood physical attacks before and after separation, as well as poverty, the indignities inflicted by welfare workers, and the threat of a custody suit. Naming the phenomenon that renewed her fear will allow her to recognize her experience and weigh the dangers of her particular situation. ${ }^{306}$ When women blame ourselves for the difficulties we face, this internalized fear becomes part of the culture of women, part of advice mothers give to daughters and friends give each other, as marriages fray and when women are threatened. Naming the assault on separation may begin to pull loose the threads of intimidation from the fabric of feminine wisdom, and to legitimate women's perception of danger while directing our attention toward the resources and support we will need, rather than to our own deficiencies or inadequacies. ${ }^{307}$

Popularizing the concept of separation assault is not without hidden dangers, however. Separation assault is effective in part because, rather than directly confronting existing stereotypes of battered women, it provides a partial explanation of women's actions that redirects attention toward the batterer. It works in part through its very resonance with existing stereotypes that ask why the woman didn't leave. Therefore, this concept alone cannot remake our understanding of domestic violence; by itself, separation assault becomes merely another explanation of the woman's apparent "failure" to separate - at worst, subtle reinforcement of existing stereotypes. Without further cultural redefinition of battering as a process of power and control, naming separation assault may not deeply challenge oppressive ideology regarding women and domestic violence. However, on a broader scale, separation assault should help the larger goal of shifting cultural perception because it helps change "objective" judgment - that is, shared cultural perceptions and wisdom - about what is normal in

306. Hart, supra note 273 , at 240-49.

307. Women often blame themselves and internalize responsibility for the violence. DOBASH \& DoBASH, supra note 12, at 119; OKUN, supra note 107, at 73. Gondolf and Fisher report studies showing women most likely to blame themselves for the first incident; after that, they increasingly blame the batterer and seek to change him. GoNDOLF \& FisHER, supra note 12, at 16. 
relationships. In the next part of this article, I explain how the redefinition of separation described above can help change legal doctrine in several areas by shifting both cultural expectation and judicial inquiry.

\section{The Uses of a Name: Separation Assault and Legal DOCTRINE}

Naming separation assault is an attempt to use a social definition, a cultural concept, to resolve doctrinal problems in law. It should not articulate a new test for women's behavior ("did this woman in fact leave and how shall we judge the energy with which she attempted separation?') but rather promote a new understanding of violence against women. As it intervenes in cultural consciousness, separation assault allows legal actors (including attorneys, prosecutors, judges, jurors, social workers, and legal scholars) to reconceive many legal questions that depend on an understanding of women's lives and experiences. Our understanding of "objective" reasonableness depends on our cultural intuitions about normal experience and normal response. By reflecting a consciousness of power and control, and by emphasizing the dangers attendant on separation, separation assault helps make women's experience comprehensible in law.

In the following sections, I show how separation assault can be identified in cases in many areas of legal doctrine, and then explain how understanding separation assault can help resolve troubled areas in law. My review of the cases and doctrines is necessarily partial and suggestive, rather than comprehensive. It is a beginning. It is intended both to invite more discussion of the ways in which litigation can help expose in both law and culture the power and control at the heart of battering, and to invite further analysis of the particular dangers to women at separation.

\section{A. Recognizing Separation Assault in the Cases: The Problem of the Dead Woman's Voice exit $\mathbf{n}$... I: a departure from a stage $2 a$. . . going away $b:$ DEATH $^{308}$}

There is a two-layered problem in seeing through the criminal cases involving abuse of women. First, these cases appear in various doctrinal guises, and few explicitly acknowledge that they concern domestic violence at all. Second, on closer examination, many of the "wife-murder" cases turn out to be "ex-wife murder," the most ex-

308. Webster's NinTH New COllegiate DictionaRy 435 (1988) (capitalization in original). 
treme violence turned against women at separation. Many of the women killed by their husbands are killed after they have separated. ${ }^{309}$ Ironically, since those women are not alive to tell their stories, their voices disappear into the narrative voices of the courts, where the women are not usually identified as battered:

On a day in early September in 1977, the petitioner and his wife of 28 years had a heated argument in their home. During the course of this altercation, the petitioner, who had consumed several cans of beer, threatened his wife with a knife and damaged some of her clothing. At this point, the petitioner's wife declared that she was going to leave him, and departed to stay with relatives. [This was not the first time that he and his wife had been separated as a result of his violent behavior.] That afternoon she went to a Justice of the Peace and secured a warrant charging the petitioner with aggravated assault. A few days later, while still living away from home, she filed suit for divorce. [A court hearing date was set and several efforts to persuade the wife to return home were rebuffed.] At some point during this period, his wife moved in with her mother .... [Several angry phone calls were exchanged, while she refused to reconcile.]

At this juncture, the petitioner got out his shotgun and walked with it down the hill from his home to the trailer where his mother-in-law lived. Peering through a window, he observed his wife, his mother-inlaw, and his 11-year-old daughter playing a card game. He pointed the shotgun at his wife through the window and pulled the trigger. The charge from the gun struck his wife in the forehead and killed her instantly. He proceeded into the trailer, striking and injuring his fleeing daughter with the barrel of the gun. He then fired the gun at his motherin-law, striking her in the head and killing her instantly. ${ }^{310}$

Godfrey v. Georgia presents an almost perfect picture of the dangers for women at separation: Mrs. Godfrey had resolutely separated from her husband and energetically sought the protection of the law. However, her story does not enter the criminal law casebook ${ }^{311}$ as a domestic violence case. Rather, Godfrey is a death penalty case presenting the issue of whether this murder was unambiguously "outrageously or wantonly vile, horrible or inhuman," or whether the case revealed ambiguity and vagueness in the death penalty statute. The Supreme Court essentially found Mrs. Godfrey's death to be quite an

309. No one has counted how many women are killed at the moment they announce that they are leaving. However, the fact that more than half of women who leave their husbands are violently harassed was noted by BROWNE, supra note 3, at 110. The tendency for separation to actually increase the incidence of violence has also been noted. See Ellis, supra note 21, at 408 (citing several studies).

310. Godfrey v. Georgia, 446 U.S. 420, 424-25 (1980).

311. See, e.g., John Kaplan \& Robert WeISBerg, Criminal LAw (2d ed. 1991), which considers Godfrey in its section on capital murder. Id. at 412. In fact, most casebooks have no category for domestic violence, though "battered woman's syndrome" may enter discussions of the duty to retreat or of diminished capacity defenses. 
ordinary murder. ${ }^{312}$ I believe the majority was correct - this was an ordinary murder - but the facts were even more ordinary than the majority realized.

Mary McNeill has shown that several torts cases on duty are actually domestic violence cases in disguise. ${ }^{313}$ However, once the domestic violence is perceived, separation assault appears to be a further hidden issue in at least one of the cases. ${ }^{314}$ In Jablonski by Pahls $v$. United States, ${ }^{315}$ Melinda Kimball had repeatedly approached the psychologists who examined the man she lived with, telling his doctors that she was afraid of him. ${ }^{316}$ They failed to commit him or to seek his medical records, which would have revealed that he had ten years earlier been diagnosed as schizophrenic and had then had homicidal ideas about his wife. ${ }^{317}$ One doctor told Kimball that she should avoid Jablonski if she feared him. Kimball left after a priest also urged her to separate from Jablonski. She was murdered when she returned to the apartment to pick up some baby diapers. ${ }^{318}$ Since there is no record of any attempt to kill her before she left, separation appears to be at least a precipitating factor in Kimball's death.

In Garcia v. Superior Court, Grace Morales was killed by Napoleon Johnson, Jr., the man from whom she had recently separated. ${ }^{319}$ According to the complaint, Johnson's parole officer was aware that Johnson had killed his first wife after she left him. ${ }^{320}$ Although he was

312. "A person of ordinary sensibility could fairly characterize almost every murder as 'outrageously or wantonly vile, horrible and inhuman." 446 U.S. at 428-29.

313. Mary McNeill, Domestic Violence: The Skeleton in Tarasoff's Closet, in DOMESTIC VIOLENCE ON TRIAL, supra note 58, at 197.

314. In one of the cases McNeill describes, Hedlund v. Superior Court, 669 P.2d 41 (Cal. 1983), facts in the opinion are insufficient to reveal whether the couple was together or separated when he shot her. Stephen Wilson and La Nita Wilson had sought counseling and psychotherapy together, though the opinion notes that they were not married and that the identity of their last names was in fact coincidental. 669 P.2d at $42-43 \&$ n.4. Stephen had informed his therapists that he intended to "commit serious bodily injury upon" La Nita. 669 P.2d at 43. When Stephen shot her, La Nita saved her three-year-old son Darryl by throwing her body across the child's. 669 P.2d at 46. The questions in the case were whether the psychologists were negligent in failing to diagnose Stephen's dangerousness and warn La Nita, and whether Darryl should recover because of his close relationship with his mother. 669 P.2d at 46, $46 \mathrm{n} .7$. Some cases McNeill discusses are ambiguous: in Tarasoff v. Regents of Univ. of Cal., 551 P.2d 334 (Cal. 1970, the dead woman had not in fact been in a relationship with her murderer, but he had imagined that a relationship existed and that she had left him. MoNeill, supra note 313, at 199. Tarasoff is therefore a separation assault from the man's point of view - from the woman's, it is a story of a stranger's obsession, a more general lesson in vulnerability to the male imagination.

315. 712 F.2d 391 (9th Cir. 1983).

316. 712 F.2d at 393-94.

317. 712 F.2d at 393-94. Apparently, this was a first wife, given the long time period and different city in which the first events took place. See 712 F.2d at 393.

318. 712 F.2d at 394.

319. 789 P.2d 960, 961-62 (Cal. 1990).

320. 789 P.2d at 962 . 
notified that Johnson had threatened to kill Morales and that Morales was filing a temporary restraining order, the parole officer advised Morales that Johnson would not come looking for her. ${ }^{321}$ Johnson kidnapped Morales and killed her; her children sued. ${ }^{322}$ The court distinguished the parole officer's "negligent representations" from a failure to warn for which the officer might have been liable under Tarasoff v. Regents of the University of California, ${ }^{323}$ and held that the plaintiffs must allege that Morales reasonably relied on the parole officer's advice. ${ }^{324}$

The California case of People v. Berry, doctrinally significant for its holding on cooling off periods when killers claim provocation by their victims, also concerns a hidden separation assault. ${ }^{325}$ The only account of the marriage is the one Berry gave the police and at trial. According to Berry's story, his wife, Rachel Pessah, had gone to Israel within days of their marriage; on her return, she taunted him about her love for another man and her plans to leave Berry. ${ }^{326}$ After repeated arguments and threats or attempts to separate, he tried to strangle her. ${ }^{327}$ He called a cab to take her to a hospital, and she later filed a police report that resulted in a warrant for his arrest. ${ }^{328} \mathrm{He}$ told her he was leaving their home and going to stay with a friend. Two days later, he returned to the apartment and waited overnight. She returned the next day and said she supposed he had come to kill her. He was indecisive, but said he had. She screamed. He strangled her. ${ }^{329}$

Even feminist literature on battering may overlook the particularity of attacks on women's autonomy. For example, the feminist newsletter Response cites the 1988 case of Balistreri v. Pacifica Police Department ${ }^{330}$ in a short article entitled "Court Rules in Favor of Abused Wife." The one-paragraph article describes Balistreri as an abused wife who sued police for not protecting her. . . . Police had refused to arrest the batterer when summoned following a beating, failed to offer medical assistance, and did not protect the woman over a 3-year

321. $789 \mathrm{P} .2 \mathrm{~d}$ at 962 .

322. 789 P.2d at 961.

323. 551 P.2d 334 (Cal. 1970), distinguished in Garcia, 789 P.2d at 963.

324. 789 P.2d at 963.

325. 556 P.2d 777 (Cal. 1976).

326. $556 \mathrm{P} .2 \mathrm{~d}$ at 779 . The expert testimony on Rachel's provocative behavior was based entirely on Berry's account of Rachel's words.

327. $556 \mathrm{P} .2 \mathrm{~d}$ at 779.

328. $556 \mathrm{P} .2 \mathrm{~d}$ at $778-79$.

329. $556 \mathrm{P} .2 \mathrm{~d}$ at 779. His previous marriage had also ended violently. Reporter's Transcript at 245-53 (on file with the author).

330. 855 F.2d 1421 (9th Cir. 1988), amended on other grounds, 901 F.2d 696 (9th Cir. 1990). 
period during which she reported incidents to police and obtained a restraining order. ${ }^{331}$

Most of the facts of Balistreri concern attacks after separation. When Balistreri's husband beat her severely in February 1982, officers failed to help her. ${ }^{332}$ She divorced her husband - apparently promptly, because "throughout 1982" she complained to police of vandalism and harassing phone calls by the husband "from whom she was now divorced." 333 In November that year, her "former husband" crashed his car into her garage, and in March 1983, a firebomb was thrown through the window of her house. ${ }^{334}$ From 1983 to 1985, telephone harassment and vandalism continued. ${ }^{335}$ Balistreri emerges as a woman of great strength - resisting her ex-husband's repeated attacks and pursuing her complaint within the legal system when her lawyer would go no further. ${ }^{336}$ "Abused wife," the term used by $R e$ sponse, captures neither her determined resistance nor her separation as the keys to the repeated violence she suffered.

\section{B. Recognizing the Danger to Women at Separation}

Recognizing the assault on separation can help disentangle a number of complex legal issues in cases in which women have been killed or harmed. In some areas of substantive law, identifying separation assault will change the questions posed by the court in its decisionmaking process. In other doctrinal areas, the shift in time frame made possible by highlighting the assault on separation can change judicial comprehension of the assault on the woman or of the probability that more assaults may occur. Separation assault may also, as in contested custody actions, help reveal underlying motivations in the legal action itself.

\section{Restraining Orders}

In some jurisdictions, when women seek orders of protection

331. Court Rules in Favor of Abused Wife, 11 Response to the VICTIMIzATION OF WOMEN AND CHILDREN No. 3, 19 (1988).

332. Balistreri, 901 F.2d at 698. It seems (from dates given for violent episodes) that the first beating mentioned in the complaint may have taken place in close connection with separation, but the facts in the opinion do not demonstrate this clearly.

333. The second amended opinion in Balistreri uses the present tense here - "from whom she is now divorced," 901 F.2d at 698 - but the first opinion used the past tense, 855 F.2d at 1423. The past tense is likely correct here, since both opinions refer to her "former husband" during this period.

334. 901 F.2d at 698.

335. 901 F.2d at 698 .

336. Balistreri won her appeal pro se; her lawyer had refused to continue working on the case after the initial dismissal for failure to state a claim. 855 F.2d at 1423. 
against violent men, courts routinely grant mutual orders of protection rather than orders specifically protecting the women. ${ }^{337}$ Mutual orders of protection direct each party not to assault, endanger, or threaten the other. ${ }^{338}$ If mutual orders are violated, police officers believe they must either arrest both parties or do nothing. The New York Task Force on Women in the Courts concluded that a woman with a mutual order of protection is in a worse position than a woman with no order at all, since the mutual order makes her look equally violent in the eyes of the courts, and the husband may not be held responsible if there is another violent incident. Also, it may be harder for her to obtain a more restrictive order if the violence recurs. ${ }^{339}$ The Task Force concluded that this was particularly dangerous if the mutual order was granted when the woman had requested protection for herself at the same time she filed an action to end the marriage - an especially dangerous period. ${ }^{340}$ Even in jurisdictions that do not routinely grant mutual orders, battering men may make cross-accusations of violence against battered women. While many battered women do fight back against their husbands, their violence is largely defensive and less severe than the men's violence - yet since it is also described as "violence," these allegations can prove troubling and confusing to judges. ${ }^{341}$

If we understood better the particular attacks women face at separation, courts could sort both cross-accusations of violence and requests for mutual orders of protection by examining the nature of current threats and the history of violence in relation to the issue of separation. The question then becomes: "Which of these people needs her [or his] capacity to separate protected?" Answering this question will help sort the dangers and should result in the grant of appropriate protective orders.

\section{Duty to Warn}

Recognizing the common occurrence of separation assault may also clarify professionals' duty to warn potential victims. For example, the Jablonski court upheld the district court's finding that the psychiatrists committed malpractice in failing to get Jablonski's records and failing to warn Kimball of his potential for violence. ${ }^{342}$ Applying

337. New York Task Force Report, supra note 51, at 38.

338. Id.

339. Id. at 39.

340. Id. at 40.

341. Saunders, supra note 38, at 103-08.

342. Jablonski by Pahls v. United States, 712 F.2d 391, 398 (9th Cir. 1983). 
the concept of separation assault does not disturb this holding. Her foreseeability as a victim would be even clearer. However, the clergyman and doctors who advised Kimball to leave Jablonski might also have had a duty to warn her about extra care to be exercised in separating from a homicidal man, as well as a duty to warn her of his dangerousness.

In Garcia v. Superior Court, ${ }^{343}$ Johnson's murder of his first wife was a separation assault of exactly the type that Johnson had threatened against Morales. The parole officer misrepresented Johnson's danger to Morales with respect to the very issue of measures regarding separation. Although the parole officer was legally barred from telling anyone the exact crime for which Johnson had previously been imprisoned, ${ }^{344}$ the court fails to reckon with the implications of the outright falsehood embodied in the parole officer's statement that Johnson's prior conviction was not for anything that endangered Morales' children. ${ }^{345}$

A telling quote in the Garcia dissent shows that judges may inappropriately assume that separation assaults will inevitably culminate in murder: the court below had concluded "it [was] highly speculative to assume that [Morales] could have accomplished any improvement in her security. The frightening reality is that for one in Morales's position there is frequently nothing she can do to protect herself." 346 When courts rely on their own intuitions to state "truths" regarding violence against women, the dangers of cultural stereotyping are severe. ${ }^{347}$ A sense of the dangers of separation should have led the court to emphasize the need not to mislead Morales as to her safety and to recognize the implications of consciously identifying the assault on separation.

343. 789 P.2d 960 (Cal. 1990).

344. 789 P.2d at 962 n.2.

345. The children are suing for the loss of their mother; both the possibility of her murder and the possibility of harm to themselves in the course of a murderous attack were "danger" shown by Johnson's prior conviction.

346. Garcia v. Superior Court, 249 Cal. Rptr. 449, 454 (Cal. Ct. App. 1988), quoted in 789 P.2d 960 (Cal. 1990) (Mosk, J., dissenting). The dissent criticized the majority opinion for essentially adopting the same view the intermediate appellate court had held. 789 P.2d at 970 (Mosk, J., dissenting).

347. See, e.g., Susan Mann, The Universe and the Library: A Critique of James Boyd White as Writer and Reader, 41 STAN. L. REv. 959, 1004 (1989) (describing oral argument during which a judge in the Third Circuit Court of Appeals noted that violent couples usually reconciled, regarding a case in which a man killed his separated partner). Mann argues for the attempt to reach judges emotionally (through use of narrative). This has some conceptual similarity to my suggested use of a cultural concept to convince judges of the danger to women. 


\section{Custody Determinations: Understanding Dominance and Time- Framing Assault}

The concept of separation assault provides insight into the difficult bargains women strike during custody determinations. Women may accept mutual orders of protection, rather than orders that specifically protect them against their batterers, in exchange for the husband's agreement not to contest custody. ${ }^{348}$ Courts often award joint custody to batterers, and some courts that do not perceive violence against the mother as an aspect of the custody determination may even award them sole custody. ${ }^{349}$ The problem is exacerbated for battered women by the professional analyses of the social workers in whom the court vests the power to evaluate women, and by the possibility that the judge will share a stereotypical, stigmatizing image of battered women.

Separation assault provides a link between past violence and current legal disputes by illuminating the custody action as part of an ongoing attempt, through physical violence and legal manipulation, ${ }^{350}$ to force the woman to make concessions or return to the violent partner. It reveals the potential for continuing danger from a batterer who may not have struck out physically in the recent past. Threats against the woman's separation attempts may reveal that the "domestic" violence has outlasted the marriage. Recognizing separation assault can therefore help judges understand the relevance of past violence and threats, and the relevance of the nature of present attacks, to custody cases. Also, when there is evidence of violent separation assault, a judge could give more intense scrutiny to the motives behind custody disputes and reconsider the appropriateness of joint custody awards or liberal visitation decrees. This would help diminish "legal separation assault" in custody cases. Finally, by remaking the cultural concept of separation, we may hope to affect positively the evaluation of women by the social workers in whom the legal system places so much power.

\section{Judging the Wife-Killer: Time-Framing, Provocation, and the Nature of the Assault}

In Berry, the defendant's arguments for a jury instruction on provocation depended entirely upon his statements that his wife had taunted him sexually and provoked her own murder. ${ }^{351}$ In fact, he did

348. New York Task Force Report, supra note 51, at 40 n.84.

349. Id. at 41-42; Achieving Equal Justice, supra note 41, at 37 (less than half of judges surveyed viewed spousal abuse as a reason not to award joint custody).

350. Batterers may seek custody as part of an overall attempt to continue controlling the woman and to punish her for separating. Walker \& Edwall, supra note 200, at 140.

351. People v. Berry, 556 P.2d 777, 778-80 (Cal. 1976). 
not kill her when she taunted him, but when she left him. ${ }^{352}$ Recognizing separation assault expands the relevant time frame to show his behavior was consistent with numerous prior assaults that seem at least as responsive to her departure as to sexual provocation. He had violently assaulted his first wife as well. ${ }^{353}$ Berry is cited for its holding that twenty hours of waiting in the apartment - some days after his wife's last "provocative" conduct - was not as a matter of law too long a period to permit an instruction on provocation. The court might have viewed the case differently had the assault on separation been as cognizable as his response to her alleged sexual taunts: it is difficult to find "heat-of-passion" in a repeatedly attempted assault carried out over a period of time. ${ }^{354}$

A short time frame favors men in these cases, as it does in many types of cases, by removing violence from a context of power and struggle. ${ }^{355}$ Prior attacks on the woman's attempts to separate may essentially be rehearsals for the final killing. ${ }^{356}$ Alternatively, the long-term assault on her separation may be perceived as one ongoing attack. If only the final, deadly assault is cognizable, the nature of the assault as an attack on separation, rather than on the woman's sexual provocation, may remain disguised. ${ }^{357}$ Separation assault can therefore change the time frame within which the man's mental state is to be evaluated by changing the perception of the ways in which the woman's autonomy is under attack.

\section{Live Women and Dead Men: The Self-Defense Cases}

The self-defense cases, which often have an extraordinarily high level of violence against women, have exercised a powerful influence on the literature on battering. Expert testimony on battered woman syndrome and learned helplessness was first introduced to explain the

352. $556 \mathrm{P} .2 \mathrm{~d}$ at $780-81$.

353. He stabbed her with a kitchen knife. Berry's account of his assault on his first wife shows that both sexual jealousy and fear of separation were present in that relationship as well. Reporter's Transcript, at 252-53 (on file with author).

354. In Terrifying Love, Lenore Walker describes a case in which the judge found the woman's act of separation to have been provocation for the man's murderous attack. The case was later reversed, however. WALKER, supra note 11, at 66-69.

355. See supra text accompanying note 350 (custody cases); infra notes 371-77 and accompanying text (self-defense cases).

\356. I am indebted to Donna Coker for suggesting this possibility. Conversation with Donna Coker, supra note 67.

357. This is a similar process to the criticism of sociological studies that only examine an accretion of acts of violence stripped of context and thereby distort the severity and meaning of acts of domestic violence. See Hoff, supra note 101, at 271-72. 
woman's actions and mental state in these cases. ${ }^{358}$ The idea that the woman should have left the relationship, and especially the idea that she failed to leave, shapes the courts' analyses of many aspects of selfdefense cases, including the reasonableness of the woman's perceptions and reactions, the imminence of the threat of death or great bodily harm, and her duty to retreat from the confrontation. In this section I first examine the relationship between the concepts of separation assault and learned helplessness. I then illustrate the relevance of the concept of separation assault to the issues of imminent danger and the reasonableness of the woman's perception that self-defense is necessary.

\section{Learned Helplessness Revisited: The Bars of the Cage}

Expert testimony on battered woman's syndrome often notes the danger of women's moves to separate from violent relationships. In a recent case, ${ }^{359}$ a California appellate court summarized Lenore Walker's testimony on battered woman's syndrome, describing the syndrome as the natural result of trauma to women. The court set forth an analysis of why women "stay in the abusive relationship," including some emphasis on the dangers of separation:

Terminating the relationship usually has adverse economic consequences. Separating from a battering partner may be very dangerous, and the battered woman is aware of the danger. The batterer may have threatened to kill the battered woman or to abscond with the children if she leaves. Many battered women have tried to leave and been unsuccessful. In a battering relationship, the woman loses self-esteem, is terrified, and does not have the psychological energy to leave, resulting in "learned helplessness" and "a kind of psychological paralysis."360

The court described a woman's "learned helplessness" as caused by random and unpredictable violence, which led her to believe that she was "incapable of doing anything to prevent the abuse." This court received a sophisticated explanation of the impact battering has on women. Yet, as the court in turn explains the woman's situation, the objective difficulties of leaving and subjective fear and helplessness are both present, but seem unrelated.

358. See, e.g., State v. Kelly: Amicus Briefs, supra note 8; supra notes 138-48 and accompanying text.

359. People v. Aris, 264 Cal. Rptr. 167 (Cal. Ct. App. 1989). In Aris, the defendant had shot and killed her sleeping husband. She appealed the exclusion of portions of proffered expert testimony on battered women and the refusal to offer jury instructions on perfect self-defense. 264 Cal. Rptr. at 171.

360. 264 Cal. Rptr. at 178. Other factors listed by the court included periodic positive reinforcement during the "loving contrition" stage of the battering cycle, and cultural training of all women to be peacekeepers, playing optimistic and hopeful roles in relationships. $264 \mathrm{Cal}$. Rptr. at 178. 
Despite its generally sympathetic attention to Walker's testimony on battered woman syndrome, the court found harmless error in excluding her further testimony, which would have linked battered woman syndrome with "the psychological symptoms and the psychological impact on the person's state of mind at the time of the homicide."361 According to the court, no jury could have found that the defendant was in imminent danger of harm from her sleeping husband at the time she shot him. ${ }^{362}$ Although separation assaults had occurred, ${ }^{363}$ the court did not weigh these past assaults on her capacity to leave when finding no imminent danger from his threat to kill her.

Learned helplessness is in essence a theory of deficiency at perceiving exit. Separation assault confirms the difficulties of exit. Separation assault does not contradict the possibility of developing learned helplessness; the woman's subjective belief could still overestimate the diffculties of leaving. Naming separation assault implies no attempt to measure the accuracy at any particular moment of a particular woman's belief in the possibility or practicality of separation. Rather, by supporting the woman's rational perception of danger, the concept of separation assault supports that aspect of battered woman's syndrome which emphasizes the woman's reasonableness and the normal character of her reaction to violence.

Separation assault is also consistent with the behavioral psychology experiments underlying learned helplessness theory. ${ }^{364}$ Walker's discussion of Seligman's dog experiment barely mentions the cages in which the dogs were held. ${ }^{365}$ Yet if the dogs had not been trapped, the shocks could not have had the same debilitating effect. Walker also described a less famous learned helplessness experiment in which baby rats were repeatedly held until they ceased struggling: when placed in water, the rats drowned because they sank immediately or gave up swimming soon. The rats were not shocked - it was essentially an experiment in captivity. ${ }^{366}$ Captivity is an important though under-

361. 264 Cal. Rptr. at 178.

362. $264 \mathrm{Cal}$. Rptr. at 181. The night of the killing, he said he did not think he would let her live until morning. $264 \mathrm{Cal}$. Rptr. at 171.

363. The defendant had repeatedly left her husband, but "[b]y a mixture of threats and cajoling, he invariably convinced her to take him back." $264 \mathrm{Cal}$. Rptr. at 171.

364. LENORE WALKER, supra note 40, at 45-47.

365. In derivative descriptions of learned helplessness, the cages may virtually disappear as a factor in creating helplessness. See, e.g., GoNDOLF \& FISHER, supra note 12, at 13 ("The animals after a series of intermittent electric shocks, eventually became immobilized. They could not escape from their cages even when an open route was provided for them.").

366. LENORE WALKER, supra note 40, at 46-47. 
emphasized component of learned helplessness - not merely the result of a psychological process that makes a woman unable to get out.

The question "why didn't she leave?" reflects a cultural failure to recognize the bars that imprison the woman in a violent marriage. Since separation assault appears in the cases where women are killed or harmed as well as the self-defense cases, the concept of separation assault helps reveal the real and deadly constraints within which learned helplessness develops. The concept of separation assault thus does not challenge the concepts of battered woman's syndrome and learned helplessness. Rather, it explains the experience of many women who may not fit well with the phenomena that distinguish learned helplessness. ${ }^{367}$ For example, in Fennell v. Goolsby, ${ }^{368}$ a federal district court described Karen Anne Fennell as an atypical battered woman because she had obtained a court order to have her husband ejected from the home and had been separated for six months. ${ }^{369}$ She had suffered incessant threats and harassment during the separation. ${ }^{370}$ The concept of separation assault would have helped refute the court's assumption that typical battered women do not seek court orders and emphasized the need for expert testimony to explain to the jury the link between Karen Anne Fennell's experience and that of other battered women.

Finally, naming separation assault cannot end the need for expert testimony on the subject of battered woman's syndrome and learned helplessness. Collectively, the jury can only "know" what it is possible for them to discuss. Women will still find it impossible to incorporate our own experience in the jury room unless the lens through which we perceive battered women has been entirely transformed. Men will also remain unable to discuss their experience as witnesses to violence against women or their capacity to seek control violently. As long as we have no way to discuss or understand the violence many of us have experienced - or to sort out what we have heard from others - there remains a critical need for expert testimony to explain to the jury things beyond their capacity for collective knowledge and discussion, even if these things are within their individual personal experience.

367. Blackman, supra note 3, at 127-28 (noting that even severely battered women may not fit the images described by battered woman syndrome and leamed helplessness descriptions).

368. 630 F. Supp. 451 (E.D. Pa. 1985).

369. 630 F. Supp. at $459-60$ \& n.4.

370. $630 \mathrm{~F}$. Supp. at 457 . The court found it had been error to exclude battered woman's syndrome testimony, but not constitutional error for purposes of habeas corpus. $630 \mathrm{~F}$. Supp. at 460-61. Even if it were constitutional error, it was harmless beyond a reasonable doubt because two psychiatrists testified to her mental state. 630 F. Supp. at 461. 


\section{Questions of Timing, Captivity, and "Objective" Perception}

The concept of "separation assault" brings the ghosts of dead women - women slain by their abusers - into court to stand beside the woman accused of killing an abusive spouse. The facts behind many, perhaps most, ${ }^{371}$ self-defense cases reveal that the woman's separation has been repeatedly and successfully attacked before she finally kills her abuser. ${ }^{372}$ With its implicit reminder of women killed during separation attacks, the concept of separation assault makes sense of the woman's fear of death and her compliance in the face of the violence that ended her previous separations. Further, by describing an assault that by its nature takes place over time, the concept of separation assault extends the time frame weighed by the court and expands the relevance of past attacks on the woman. ${ }^{373}$ Finally, of crucial impor-

371. We will not know how many are separation attacks until we ask question designed to elicit information about the various types of assault leveled against the woman's moves to separate. The facts that appear in court opinions may include some - but not all - of the ways the woman's separation was attacked.

372. Ann Jones vividly describes the assaults on the efforts to separate of many women who ultimately killed battering men, either during or after the separation attack, often after being held prisoner or prevented from leaving at all in a variety of ways:

Homicide is a last resort, and it most often occurs when men simply will not quit. As one woman testified at her murder trial, "It seemed like the more I tried to get away, the harder he beat me." Gloria Timmons left her husband, but he kept tracking her down, raping and beating her; finally when he attacked her with a screwdriver, she shot him. $\mathrm{Pa}$ tricia Evans filed for divorce, but her husband kept coming back to beat her with a dog chain, pistol-whip her, and shoot at her. At last, after she had been hospitalized seven times, she shot him. ... Janice Strand was forced to return to her husband when he threatened her parents' lives. Patricia Gross' husband tracked her from Michigan to Mississippi and threatened to kill her relatives there to force her to return to him. . . Mary McGuire's husband, teaching submission, made her watch him dig her grave, kill the family cat, and decapitate a pet horse. When she fled he brought her back with a gun held to her child's head. ... Agnes Scott's husband found her and cut her up seven years after she left him. There are cases on record of men still harassing and beating their wives twenty-five years after the wives left them and tried to go into hiding. If researchers were not quite so intent upon assigning the pathological behavior to the women, they might see that the more telling question is not "Why do the women stay?" but "Why don't the men let them go?"

JONES, supra note 21 , at 298-99.

373. Shifting the time frame may also be useful in jurisdictions that impose a duty to retreat before using deadly force in self-defense. Retreat can be reconceptualized as a question of the scope of the attack. First, the prevalence of separation attack means that retreat may only stimulate the man's violence.' Second, by expanding the description of the time period involved in the assault on the woman, the concept of separation assault helps move toward dynamic portrayal of the power and control in the relationship. Finally, recognizing separation assault would permit us to argue that a woman need only fulfill her duty to retreat once - that she need not retreat an unlimited number of times from dangerous assaults - and that any woman who has had her separation violently attacked has already fulfilled her duty to retreat. For this question, at least, the proof of past separation assault could itself be taken as the answer to a legal question.

Although only a minority of states impose a duty to retreat when an individual is attacked in the home by another legal resident of that home, see Thomas Katheder, Case Note, Lovers and Other Strangers: Or, When Is a House a Castle, 11 FLA. ST. U. L. ReV. 465, 473-74 nn.40-41 (1983), the question "why didn't she leave" is, subtextually, a question of retreat any time it is posed in relation to the period directly preceding the assault, rather than to the woman's role in the entire relationship. See Walker, Thyfault \& Browne, Beyond the Jurors' Ken: Battered Women, 7 VT. L. REV. 1, 5 (1982). Retreat is a hidden question in cases like Stewart and Norman, 
tance in women's self-defense claims, this reconceptualization of the assault on the woman helps clarify the existence of imminent danger of death or great bodily harm.

Imminence has proved crucial in cases involving the death of sleeping husbands. Two states have recently held that women who shot sleeping husbands were not entitled to jury instructions on selfdefense because the woman faced no imminent danger of death or grave bodily harm. ${ }^{374}$ This meaning of imminent harm is not universal. "Imminent" is often distinguished from "immediate," and courts and scholars have criticized decisions that confuse the two. ${ }^{375}$ The Model Penal Code does not require that the danger actually be immediate: rather, the actor must believe that the defensive action is immediately necessary and that the force against which she defends will be used on the present occasion, "but he [sic] need not apprehend that it will be immediately used." 376 Some states have overturned jury instructions that required that the attack on the woman pose an "immediate" danger of death or great bodily harm, and have upheld statutory standards that require only that the harm be "imminent," a term that broadens the context to include more of the facts and circumstances of the woman's experience in the relationship. ${ }^{377}$ Even when a statute required "immediate danger," one court has required an overall consideration of the woman's circumstances and described as "imminent," rather than immediate, the threat necessary to justify the use of deadly force. ${ }^{378}$ Therefore, the recent decisions construing imminence as virtually equivalent to immediacy place significant limits on the ability of women to raise claims that they acted in self-defense.

in which the woman's ability to leave the house rather than shoot her abuser is explicitly raised by the majority opinions. State v. Stewart, 763 P.2d 572, 578 (Kan. 1988); State v. Norman, 378 S.E.2d 8, 13 (N.C. 1989). By shifting the lens to emphasize prior assaults on separation, women who have fled in the past can be shown to have fulfilled a duty to retreat - whether this duty is explicitly imposed by law or implicitly read into a situation by the way a judge perceived the facts.

374. Stewart, 763 P.2d at 573; Norman, 378 S.E.2d at 8-9; see also People v. Aris, 264 Cal. Rptr. 167 (Cal. Ct. App. 1989).

375. See, e.g., Norman, 378 S.E.2d at 13 (noting that interpreting "imminent" to mean "immediate" effectively denies a woman the right to self-defense); GILLESPIE, supra note 11, at 64 77, 185-87; see also State v. Hodges, 716 P.2d 563, 570-71 (Kan. 1986). But see Cathryn Jo Rosen, The Excuse of Self-Defense: Correcting a Historical Accident on Behalf of Battered Women Who Kill, 36 AM. U. L. REv. 11, 29 n.107 (common law usually equated imminence with immediacy, though Model Penal Code does not).

376. Model Penal Code $\S 3.04 \mathrm{cmt}$. 2(c)(1985), quoted in Norman, 378 S.E.2d at $19 \mathrm{n} .1$ (Martin, J., dissenting).

377. See Gillespie, supra note 11, at 185-87; see also Hodges, 716 P.2d 563; State v. Osbey, 710 P.2d 676 (Kan. 1985), State v. Hundley, 693 P.2d 475 (Kan. 1985).

378. State v. Gallegos, 719 P.2d 1268 (N.M. Ct. App. 1986); see also State v. Wanrow, 559 P.2d 548 (Wash. 1977). The jury instruction using an immediacy standard was held to overly restrict the inquiry into the defendant's circumstances. 559 P.2d at 555-56. 
State v. Stewart ${ }^{379}$ is the latest in a line of Kansas cases to grapple with the meaning of "imminent" and the relevant context for evaluating the woman's action. Stewart marks a return to a requirement of immediacy despite a factual background that strongly suggested an expanded contextual approach was relevant. Peggy Stewart married Mike Stewart in 1974. ${ }^{380}$ She had two young daughters, Carla and Laura, from previous marriages. Mike was abusive from the beginning. Peggy soon developed severe psychological problems and was treated for schizophrenia. ${ }^{381}$ Mike tampered with her medication, forcing her to take too much at times and to do without her medication at other times. ${ }^{382}$ Mike severely abused Peggy's daughter Carla. When he ordered Peggy to kill and bury Carla, Peggy filed for divorce, ${ }^{383}$ but the case does not indicate that she followed through with the divorce action. When Carla was twelve years old, Mike threw her out of the house with "no coat, no money, and no place to go."384 $\mathrm{He}$ forbade Peggy to have any contact with Carla. ${ }^{385}$ Laura left home as soon as she could. ${ }^{386}$

Both the majority and dissenting opinions in Stewart chronicle an extraordinarily violent and abusive marriage in which Peggy's life was repeatedly threatened. Mike shot Peggy's cats and then held the gun to Peggy's head, threatening to shoot; ${ }^{387}$ another time, he threatened her with a loaded shotgun. She told her friends she believed he would kill her one day. ${ }^{388}$ Finally, Peggy ran away to Laura's house in another state. ${ }^{389}$ Peggy was suicidal, and Laura had her admitted to a mental hospital, where she was diagnosed as having reacted to an overdose of her medication. 390 Though Peggy told a nurse that she felt like she wanted to shoot Mike, the nurse noted that Peggy's main emotion seemed to be hopelessness. ${ }^{391}$ Mike telephoned the hospital

379. 763 P.2d 572 (Kan. 1988).

380. 763 P.2d at 574.

381. 763 P.2d at 574.

382. 763 P.2d at 574 (made her take more than prescribed medication); 763 P.2d at 581 (Herd, J., dissenting) (overdosed her on medication and then cut it off).

383. 763 P.2d at 574.

384. 763 P.2d at 574.

385. 763 P.2d at 574 .

386. 763 P.2d at 581 (Herd, J., dissenting).

387. 763 P.2d at 575 .

388. 763 P.2d at 575.

389. The court states that this was the first time she left Mike without telling him. 763 P.2d at 575. However, it could not have been her first attempt to separate, since the facts reveal that a divorce action was at least undertaken at some earlier time.

390. 763 P.2d at 575.

391. 763 P.2d at 581 (Herd, J., dissenting). 
to say he was coming to get her, and she agreed to leave with him. ${ }^{392}$ At trial, she testified that she decided to go with him because the hospital did not provide the medical help she needed. ${ }^{393}$

Mike drove Peggy back to Kansas. He told her that "if she ever ran away again, he would kill her." $394 \mathrm{He}$ "forced Peggy into the house and forced her to have oral sex several times" 395 with such force that the inside of her mouth was bruised ${ }^{396}$ — that is, he raped her repeatedly - while telling her how much he preferred other women. She discovered bullets and a loaded gun, which frightened her because he had promised to keep his guns unloaded. ${ }^{397}$ She hid the gun. ${ }^{398}$ Mike made repeated remarks indicating that "she would not be there long, and could not take her things where she was going," which led her to think that he meant she would soon be dead. ${ }^{399}$ He ceased the abuse for a brief period while his parents came over to visit, then forced her to perform oral sex again and demanded that she come to bed with him. As he slept, she heard voices telling her "kill or be killed." Peggy got the gun she had found and hidden earlier, and she shot Mike as he slept. 400

The Kansas Supreme Court held Peggy was not entitled to a jury instruction on self-defense, since she was in no imminent danger when she shot Mike. "Under such circumstances, a battered woman cannot reasonably fear imminent life-threatening danger from her sleeping spouse."401 The court distinguished three of its prior cases in which abused women had killed violent husbands. In State v. Hundley, ${ }^{402}$ State v. Osbey, 403 and State v. Hodges, ${ }^{404}$ the Kansas Supreme Court had held that the statutory requirement of imminence permitted consideration of the history and gradual build-up of violence within a relationship as well as the immediate acts of the batterer. Although

392. 763 P.2d at 581 (Herd, J., dissenting).

393. 763 P.2d at 575.

394. 763 P.2d at 581 (Herd, J., dissenting).

395. 763 P.2d at 575 .

396. 763 P.2d at 581 (Herd, J., dissenting).

397. $763 \mathrm{P} .2 \mathrm{~d}$ at 575.

398. 763 P.2d at 575 .

399. 763 P.2d at 575.

400. 763 P.2d at 575.

401. 763 P.2d at 578. The court also overruled an earlier holding that measured the reasonableness of perception of harm from the subjective viewpoint of the battered woman. $763 \mathrm{P} .2 \mathrm{~d}$ at 579 (overruling in part State v. Hodges, 716 P.2d 563 (Kan. 1986)). See infra text accompanying notes 425-27.

402. 693 P.2d 475 (Kan. 1985).

403. 710 P.2d 676 (Kan. 1985).

404. Hodges, 716 P.2d 563. 
none of these had directly confronted the question of the propriety of giving a self-defense instruction, ${ }^{405}$ they had rejected the use of the term "immediate" in explaining the imminence standard.406 The Stewart court did not directly overrule its prior holdings but distinguished the previous imminence cases as "involv[ing] a threat of death to the wife and a violent confrontation between husband and wife, contemporaneous with the shooting." 407 As the Stewart dissent pointed out, however, this holding effectively replaced the state's prior definition of "imminent" with an immediacy standard. 408

In holding that there was no "imminent" threat to Peggy, the majority ignored the imprisoning effect of Mike's bringing her back from another state after her effort to separate and his threat to kill her if she left again. In contrast, the dissent emphasized Mike's threat to kill Peggy if she separated from him again. ${ }^{409}$ The concept of an assault on separation continued over time may help courts appreciate the crucial distinction between imminence and immediacy in self-defense cases such as Stewart.

Separation assault can help reveal captivity. In Hundley, the Kansas Supreme Court drew an analogy between battered women and hostages or prisoners of war. ${ }^{410}$ The Stewart dissent repeated this analogy and argued the Stewart holding would preclude finding imminence in "a hostage situation where the armed guard inadvertently drops off to sleep and the hostage grabs his gun and shoots him."411 This could be a persuasive analogy: If a hostage were told, "you will be killed in three days," the danger would still appear imminent even if not immediate. ${ }^{412}$ The question of imminence therefore appears to be affected by an assessment of the nature and degree of the hostage's captivity; the persuasive power of the hostage analogy depends on the recognition that the woman in an abusive relationship is not free to leave. At issue is our understanding of the woman's functional autonomy. The key difference between the analysis of the majority and dissent in Stew-

405. 763 P.2d at 578. Hodges, for example, dealt with the language of the self-defense instruction. 716 P.2d at 570-71. The state apparently did not object to the giving of a self-defense instruction in that case.

406. 763 P.2d at 584-85 (Herd, J., dissenting).

407. 763 P.2d at 578 .

408. 763 P.2d at 584-85 (Herd, J., dissenting).

409. 763 P.2d at 581 (Herd, J., dissenting).

410. State v. Hundley, 693 P.2d 475, 479 (Kan. 1985).

411. 763 P.2d at 584 (Herd, J., dissenting).

412. I am indebted to Mary Coombs for this discussion. Conversation with Mary Coombs, (Sept. 1990); see also M.J. Willoughby, Comment, Rendering Each Woman Her Due: Can A Battered Woman Claim Self-Defense When She Kills Her Sleeping Batterer?, 38 U. KAN. L. Rev. $169,184-85$ (1990) (comparing battered women to hostages). 
art is how seriously each takes the constraints Mike imposed on Peggy's capacity to separate.

Had the Stewart majority been able to perceive Mike's successful assault on Peggy's separation, they could have found a common thread of separation assault linking Stewart with Hundley, Osbey, and Hodges. ${ }^{413}$ In Hundley, the wife shot her husband as he attacked her in the motel room to which she had moved after leaving him. ${ }^{414}$ In Osbey, the wife had insisted on a separation after a history of substantial abuse. ${ }^{415}$ The husband was in the process of moving out when he changed his mind, telling a friend he had put too much time into his wife's house and that "it would be either [him] or her."416 $\mathrm{He}$ had [previously] threatened her with a gun.417 She shot him when she thought he reached for a weapon as he attempted to return some of his belongings to the apartment.418 In Hodges, the wife had continually left her husband early in their marriage only to have him pursue her and brutally fetch her back. On one such occasion

$[\mathrm{H}] \mathrm{e}$ took her to a wooded location where he beat her, broke her jaw, and said she was either going to live with him or she wasn't going to live. He left her there unconscious, but eventually returned, took her to the hospital, and told her to tell the hospital staff she fell down. She returned home with him because he had her children. ${ }^{419}$

She finally succeeded in divorcing him but reunited thirteen years later because he promised he had changed. ${ }^{420}$ When the beatings did not stop, she left again; however, when he again brought her back, she gave up trying to leave him. He had also threatened her family if they ever helped her leave him.421 She shot him as he engaged in yet another bout of violence. ${ }^{422}$

The concept of separation assault thus bridges the difference between cases like Stewart that involve sleeping husbands and those like Hundley, Osbey, and Hodges that involve waking husbands. In

413. Unsuccessful separation attempts are also present in many other cases on self-defense and battered woman's syndrome. For example, in State v. Gallegos, 719 P.2d 1268 (N.M. Ct. App. 1986), the woman told the man in the midst of a long day of violence that she was tired of being hurt and that she would leave him. He "pulled out his gun and threatened to kill her if she left." 719 P.2d at 1272. Similarly, in Smith v. State, 277 S.E.2d 678 (Ga. 1983), Jo Smith tried to flee before her attacker slammed the door on her; finally, she shot him. 277 S.E.2d at 679.

414. 693 P.2d at 476.

415. 710 P.2d at $677-78$.

416. 710 P.2d at 678 .

417. 710 P.2d at 678.

418. 710 P.2d at 678.

419. 716 P.2d at 566-67.

420. 716 P.2d at 566-67.

421. 716 P.2d at 567.

422. 716 P.2d at 567. 
Hodges, expert testimony on battered women was allowed in part to "help dispel the ordinary layperson's perception that a woman in a battering relationship is free to leave at any time." 423 This same "perception" clearly underlies the majority opinion in Stewart, which, in deciding that Peggy was not in imminent danger, specifically noted that Peggy had access to the car keys - without reviewing the threat to her life if she used them to escape.424

Finally, the Stewart opinion emphasized a requirement of objective reasonableness in the battered woman's self-defense claims. In Hodges, Kansas had held that "the jury must determine, from the viewpoint of the defendant's mental state, whether defendant's belief in the need to defend herself was reasonable."425 Stewart overruled Hodges on this point, holding that after determining whether the defendant subjectively sincerely and honestly believed it necessary to kill in self-defense, "We then use an objective standard to determine whether defendant's belief was reasonable - specifically, whether a reasonable person in defendant's circumstances would have perceived self-defense as necessary." 426 The objective standard to be applied is how a "reasonably prudent battered wife" would have perceived the aggressor's demeanor. ${ }^{427}$ Separation assault is important here as well. The cultural redefinition of the dangers of separation goes beyond the individual woman's "subjective" perception of danger; it does not merely bolster her argument that under her particular, individual circumstances, her subjective perceptions (though unreasonable for a "normal person") persuaded her of danger. Rather, separation assault helps shift what judges and jurors "objectively" know as truth: To the extent that objective standards embody in law the shared cultural norms of society, separation assault helps restructure those norms to allow "objective" perception itself to track more closely the painfully accrued understanding of women who have lived with violent partners.

A recent North Carolina self-defense case involving a sleeping husband exemplifies perhaps even more dramatically than Stewart the urgent need for a better judicial understanding of separation assault. In State v. Norman, ${ }^{428}$ a North Carolina court of appeals held that a woman who had shot her sleeping husband was entitled to a jury instruc-

423. 716 P.2d at 567.

424. State v. Stewart, 763 P.2d 572 (Kan. 1988).

425. State v. Hodges, 716 P.2d 563 (Kan. 1985).

426. 763 P.2d at 579.

427. 763 P. $2 \mathrm{~d}$ at 579.

428. 366 S.E.2d 586 (N.C. Ct. App. 1988), revd., 378 S.E.2d 8 (N.C. 1989). 
tion on perfect self-defense. The North Carolina Supreme Court reversed, holding that there was no imminent danger to the wife. ${ }^{429}$ Judy Norman had been subjected to vicious torture and degradation over a period of twenty years. Her husband, John Thomas (J.T.) Norman, had beaten her, thrown objects at her, put out cigarettes on her skin, and broken glass on her face. He forced her to prostitute herself daily to support him and then ridiculed her to family and friends. $\mathrm{He}$ called her a "dog," forced her to bark like a dog, eat pet food out of pet dishes, and sleep on the floor. ${ }^{430} \mathrm{He}$ deprived her of food for days at a time and had "often stated both to defendant and others that he would kill [her] . . . [and] threatened to cut her heart out."431 She left him several times, but each time he found her, took her home, and beat her. ${ }^{432}$

The thirty-six hours before Judy Norman shot her husband were marked by incredible violence, which escalated after her husband was arrested for drunken driving. He beat her almost continuously, refused to eat food that her hands had touched, refused to let her eat for a period of days, threatened to cut off her breast and "shove it up her rear end," 433 and put out a cigarette on her chest.

On the first evening after the drunken driving arrest, Judy called the police for help. An officer told her they could only help if she filed a complaint ("[took] out a warrant on her husband"). ${ }^{434}$ She replied that "if she did so [her husband] would kill her."435 An hour later, she swallowed a bottle of "nerve" pills, 436 and her family called for help. Her husband told the paramedics to let her die and repeatedly obstructed their attempts to save her. ${ }^{437}$ The police did not arrest him for attempting to block her rescue: "When he refused to respond to the officer's warning that if he continued to hinder the attendants, he would be arrested, the officer was compelled to chase him back into the house."438 At the hospital, Judy Norman spoke to a therapist and discussed filing charges against her husband and having him committed for treatment. ${ }^{439}$ She seemed depressed and said she should kill

429. State v. Norman, 378 S.E.2d 8, 12 (N.C. 1989).

430. 378 S.E. $2 d$ at $9-10$.

431. 366 S.E.2d at 587.

432. 366 S.E.2d at 589 .

433. 366 S.E.2d at 588 .

434. 378 S.E.2d at 19 (Martin, J., dissenting).

435. 378 S.E.2d at 19 (Martin, J., dissenting).

436. 366 S.E.2d at 588.

437. 366 S.E.2d at 588 .

438. 378 S.E.2d at 19 (Martin, J., dissenting).

439. 378 S.E.2d at 10 (Martin, J., dissenting). 
him for what he had done to her. She stayed at her grandmother's that night. 440

The next day, she went to the mental health center to discuss charges and the possibility of her husband's commitment and "confronted [him] with that possibility." 441 Her husband told her that if he saw them coming to take him away, he would cut her throat before he could be committed. ${ }^{442}$ She went to apply for welfare benefits, ${ }^{443}$ but her husband followed her there, interrupted her interview, and forced her to return home with him. ${ }^{444} \mathrm{He}$ continued to beat her and abuse her physically and would not permit her to eat or feed her children. ${ }^{445}$ He later lay down to take a nap, but made her lie on the concrete floor next to the bed, because "dogs" couldn't lie on beds. ${ }^{446}$ While he slept, her infant grandchild began to cry. She took the baby to her mother's house for fear it would awaken him. Judy's mother had placed a gun in her purse from fear of Judy's husband. At her mother's house, Judy asked for an aspirin, found the gun, returned home, and shot him.

\section{The North Carolina Supreme Court held that}

all of the evidence tended to show that the defendant had ample time and opportunity to resort to other means of preventing further abuse by her husband. There was no action underway by the decedent from which the jury could have found that the defendant had reasonable grounds to believe either that a felonious assault was imminent or that it might result in her death or great bodily injury. Additionally, no such action by the decedent had been underway immediately prior to his falling asleep. ${ }^{448}$

It is hard to know where to begin to discuss Norman. In the face of all the grave danger and murderous violence the opinion overlooks, ${ }^{449}$ it seems presumptuous to claim that the concept of separa-

440. 378 S.E.2d at 20 (Martin, J., dissenting).

441. 378 S.E.2d at 11 .

442. 378 S.E.2d at 11 .

443. 378 S.E.2d at 11. This may have been another separation attempt.

444. 378 S.E.2d at 11.

445. 378 S.E. $2 d$ at 11.

446. 378 S.E.2d at 20 (Martin, J., dissenting).

447. 378 S.E.2d at 20 (Martin, J., dissenting).

448. 378 S.E.2d at 13 .

449. In Norman, so much disappears from both the majority and dissenting opinions. Forced prostitution - essentially, third-party rape - must by the terms of the discussion have been considered something other than "great bodily harm." Or, perhaps, since she had experienced this particular bodily harm for many years, it no longer amounted to "great" harm. The Norman court indicated that the type of harm required was "life-threatening" injury and denied that her husband had inflicted any such harm on her, "even during the 'reign of terror." " 378 S.E.2d at 15. In addition, the facts of the case show that he had prevented her from eating for three days and had given no indication of when he might permit her to eat again. Surely this also 
tion assault could have remade the Norman holding. Yet the idea that Judy Norman was not captive is crucial to the majority's finding that she faced no imminent threat. The dissent is clearly groping for just such a concept in its attempt to describe what had happened to her. The dissent first quotes a psychologist, an expert witness, who compared Judy Norman to a brainwashed prisoner of war and described her as "a woman incarcerated by abuse, by fear, and by her conviction that her husband was invincible and inescapable . . .":450

Mrs. Norman didn't leave because she believed, fully believed that escape was totally impossible. There was no place to go .... . [S] he had left before; he had come and gotten her. She had gone to the Department of Social Services. He had come and gotten her. The law, she believed the law could not protect her, no one could protect her, and I must admit, looking over the records, that there was nothing done that would contradict that belief. 451

The concept of separation assault addresses a major problem with sleeping husband cases like Norman and Stewart. These cases look to courts like executions; judges express concern over the specter of homicidal self-help for battered wives. ${ }^{452}$ Separation assault replaces this image - as the dissenting judges in Stewart urged - with the paradigm of hostages resisting their captors. We believe the danger to a hostage is imminent both because the force used to hold them there is apparent and because our cultural knowledge includes the memory of the many hostages who have been harmed in the past. Courts might see Judy Norman very differently if they understood that she could as easily be Mrs. Godfrey (shot to death in her mother's trailer), or Rachel Pessah (the dead wife in Berry), or Grace Morales (the murdered mother in Garcia). By emphasizing the similarities between past and current uses of force, by emphasizing that force which holds the woman captive, and by persuasively invoking the shadow of many past

threatened great bodily harm. Also, the day before he died, her husband had essentially attempted her murder: rather than fulfilling his duty to save her life when she attempted suicide, he had done all he could to cause her to die and prevent others from saving her. He had sworn persuasively to her and to others that he would kill her in the future. Her whole family was convinced that he would kill her, and would kill them if they intervened. 378 S.E.2d at 19-20 (Martin, J., dissenting).

450. 378 S.E.2d at 17 (Martin, J., dissenting).

451. 378 S.E.2d at 17 (Martin, J., dissenting). The dissent concludes that a juror could have found "that defendant believed that her husband's threats to her life were viable, that serious bodily harm was imminent, and that it was necessary to kill her husband to escape that harm ... [a] juror could find defendant's belief in the necessity to kill her husband not merely reasonable but compelling." 378 S.E.2d at 20 (Martin, J., dissenting).

452. See, e.g., Norman, 378 S.E.2d at 15 ("Homicidal self-help would then become a lawful solution, and perhaps the easiest and most effective solution, to this problem."); see also State v. Stewart, 763 P.2d 572, 579 (Kan. 1988) ("To hold otherwise in this case would in effect allow the execution of the abuser for past or future acts and conduct."). 
assaults that have resulted in the death of women, separation assault helps shift the paradigm from the image of vigilantism to the image of a hostage resisting her own death. Here, at the intersection of legal standards and cultural perception, separation assault helps to reveal that by its very nature battering implicates questions of both violence and power, and to make possible a greater cultural understanding of the lives and experience of women.

\section{CONCLUSION}

Violence is a way of "doing power" in a relationship; 453 battering is power and control marked by violence and coercion. $A$ battered woman is a woman who experiences the violence against her as determining or controlling her thoughts, emotions, or actions, including her efforts to cope with the violence itself. Many, many women experience such violence in our society. The precise response of any woman is likely to be determined by her life circumstances and family situation.

We should know this. Nothing in the preceding paragraph should make women ashamed of being battered. However, the interrelationship among cultural images, legal images, litigation, and substantive law has made it difficult for women to understand our experience of violence. The stereotypical image of a battered woman - dysfunctional, helpless, dependent - is alien to the self-image and self-knowledge of most women who encounter violence from our partners. Attempts to counter these stereotypes have interacted with other contemporary social and legal developments: each block of legal reform (such as the development of expert testimony on battered women) has interacted with the rest of the legal structure (such as the advent of nofault divorce, or the evidentiary rules governing the admission of expert testimony) to pose continued difficulties in recognizing women's experience in law.

These reciprocal, mutually reinforcing forces of popular perception, law, and litigation have made it difficult for women to identify ourselves and our experience as part of a continuum of power and domination affecting most women's lives. The challenge is to identify legal and social strategies that will allow us to change law and culture simultaneously, by illuminating the context of power and control within which a woman lives and acts. Naming separation assault can help reveal the overall struggle for power that is the heart of the battering process: it describes a particularly dangerous attack hitherto hidden in the phrase "domestic violence," emphasizes the assault on

453. STETS, supra note 64 , at 109. 
the woman's autonomy and volition, and offers insights that can help resolve several troubled areas of law. This intervention is both legal and cultural, a way to rewrite legal doctrine by changing the way we understand the questions and categories involved.

I offer the theory of separation assault as part of a feminist approach to law reform in this area: working from women's experience, we must develop legal and cultural strategies that more clearly reveal the struggles we face. We need many such interventions. The key to more widespread change lies in the way transformed legal and social images of women will in turn affect women's experience and understanding of our lives, allowing women to recognize our experience as part of a larger system of subordination so that we can structure our understanding of our needs in relation to those of other women facing oppression. Women's recognition of our own oppression has been slowed by the images that law has helped create. As we come to recognize our experiences as oppression, rather than personal insuffciency, weakness, or "unhappiness" in marriage - for example, recognizing separation assault rather than "failure" to leave a relationship - we will be better able to address the dangers we face and realize our individual and collective capacity for change. 